\title{
Design, Synthesis, and Biological Evaluation of 2-Nitroimidazopyrazin-one/-es with Antitubercular and Antiparasitic Activity
}

\author{
Angie M. Jarrad, ${ }^{\dagger, \Phi, \perp \odot \odot ~ C h e e ~ W e i ~ A n g, ~}{ }^{\dagger, \perp}$ Anjan Debnath, ${ }^{\ddagger}$ Hye Jee Hahn, ${ }^{\ddagger}$ Kyra Woods, ${ }^{\S}$
} Lendl Tan, ${ }^{\S, \square}$ Melissa L. Sykes, $\|$ Amy J. Jones, ${ }^{\prime}$ Ruby Pelingon, ${ }^{\dagger}$ Mark S. Butler, ${ }^{\dagger}{ }^{\odot}$ Vicky M. Avery,"

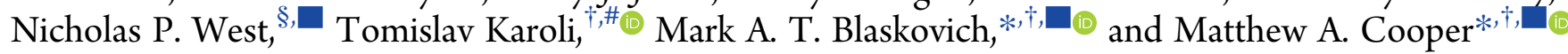

${ }^{\dagger}$ Institute for Molecular Bioscience and ${ }^{\S}$ School of Chemistry and Molecular Bioscience, The University of Queensland, St Lucia, Queensland 4072, Australia

${ }^{\ddagger}$ Center for Discovery and Innovation in Parasitic Diseases, Skaggs School of Pharmacy and Pharmaceutical Sciences, University of California San Diego, La Jolla, California 92093, United States

"Discovery Biology, Griffith Institute for Drug Discovery, Griffith University, Nathan, Queensland 4111, Australia

- Australian Infectious Diseases Research Centre, St. Lucia, Queensland 4067 Australia

Supporting Information

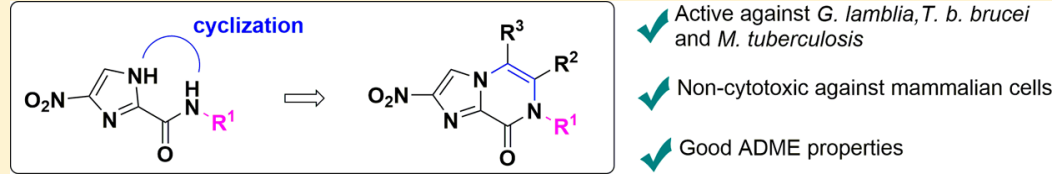

ABSTRACT: Tuberculosis and parasitic diseases, such as giardiasis, amebiasis, leishmaniasis, and trypanosomiasis, all urgently require improved treatment options. Recently, it has been shown that antitubercular bicyclic nitroimidazoles such as pretomanid and delamanid have potential as repurposed therapeutics for the treatment of visceral leishmaniasis. Here, we show that pretomanid also possesses potent activity against Giardia lamblia and Entamoeba histolytica, thus expanding the therapeutic potential of nitroimidazooxazines. Synthetic analogues with a novel nitroimidazopyrazin-one/-e bicyclic nitroimidazole chemotype were designed and synthesized, and structure-activity relationships were generated. Selected derivatives had potent antiparasitic and antitubercular activity while maintaining drug-like properties such as low cytotoxicity, good metabolic stability in liver microsomes and high apparent permeability across Caco-2 cells. The kinetic solubility of the new bicyclic derivatives varied and was found to be a key parameter for future optimization. Taken together, these results suggest that promising subclasses of bicyclic nitroimidazoles containing different core architectures have potential for further development.

\section{INTRODUCTION}

Infectious diseases are an enormous global health burden. The nitroimidazole class of antibiotics, exemplified by metronidazole (1, Figure 1), has a long history of use to treat bacterial and parasitic infections. ${ }^{1}$ The mode of action of nitroimidazoles involves partial reduction of the nitro group and subsequent decomposition of the compound to give toxic radical species that cause DNA and protein damage. ${ }^{1}$ The nitro group is activated by different mechanisms, with multiple enzymes involved in electron transfer reactions in different target organisms, which accounts for the remarkably broad spectra of action of the class. More recently, there have been issues with clinical efficacy that are accompanied, in some cases, by development of resistance, which has prompted reexamination of this old, but still widely used drug class.

New clinical applications of "old" nitroimidazoles and the development of novel nitroimidazoles with a bicyclic core scaffold architecture have significant potential to address the emergent unmet medical need imparted by resistant bacteria and parasites. For example, secnidazole (2, Figure 1) was recently approved in the USA for the treatment of bacterial vaginosis, despite being available earlier as a generic in many jurisdictions. $^{2,3}$ A pediatric formulation of benznidazole 3 (Figure 1), a 2-nitroimidazole used for the treatment of Chagas disease caused by the parasite Trypanosoma cruzi, gained FDA approval in 2017 for use in children. ${ }^{4}$ The Drugs for Neglected Diseases initiative (DNDi) is currently investigating fexinidazole (4, Figure 1) as a candidate for oral treatment of human African trypanosomiasis (HAT), a parasitic infection caused by Trypanosoma brucei spp. that is a public health threat to $\sim 70$ million people in Africa. ${ }^{5}$ In November 2018 the European Medicines Agency recommended approval of fexinidazole as the first all-oral treatment for sleeping sickness. Furthermore, bicyclic nitroimidazoles, such as delamanid (5, Figure 1) and pretomanid (6, PA-824), are promising new antimicrobials being developed for the treatment of tuberculosis (TB), ${ }^{6}$ the number one cause of death from infectious diseases and the

Received: October 10, 2018

Published: November 23, 2018 


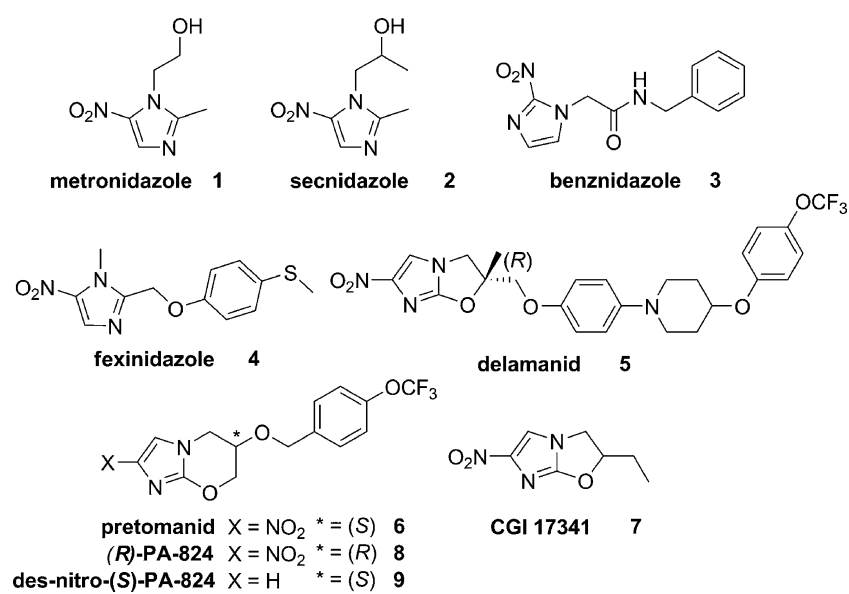

Figure 1. Monocyclic nitroimidazoles $1-4$ and the bicyclic variants delamanid (5), pretomanid (6), CGI 17341 (7), and (R)-PA-824 (8).

ninth leading cause of death worldwide. ${ }^{7}$ The nitroimidazooxazole 5 gained conditional approval in the European Union in 2014 for the treatment of drug-resistant TB. This agent was derived from CGI $17341(7)^{8,9}$ and overcame the mutagenic liability of 7 (Figure 1). ${ }^{10,11}$ Meanwhile, 6 was developed concurrently with $\mathbf{5}$ and is currently in phase III trials. The PK profile of $\mathbf{6}$ is superior to 5 and this permits once daily dosing, although 6 is less potent. ${ }^{12}$

Investigations on how $\mathbf{5}$ and $\mathbf{6}$ inhibit Mycobacterium tuberculosis under aerobic and anaerobic growth conditions revealed an interesting dual mode of action. Transcriptional profiling of M. tuberculosis treated with 6 under aerobic growth conditions gave a response consistent with both the inhibition of cell wall mycolic acid biosynthesis and also respiratory poisoning. ${ }^{13}$ Additionally, it was shown that deazaflavindependent nitroreductase $(\mathrm{Ddn})$ catalyzed reduction of $\mathbf{6}$ to the des-nitro 9 metabolite and that this process generated nitric oxide. ${ }^{14}$ Nitric oxide could be detected in Mycobacterium bovis cells treated with 6 under both aerobic and anaerobic growth conditions and the rate of $\mathrm{NO}$ release in $\mathrm{M}$. bovis cells correlated with the anaerobic activities for a series of analogues, supporting the premise that this is the mode of action of this class under anaerobic growth conditions in $M$. tuberculosis. ${ }^{14}$ In comparison, $\mathbf{1}$ is only active against nonreplicating $M$. tuberculosis under anaerobic growth conditions $(<0.06 \%$ oxygen $) .^{15}$ Nitroimidazooxazine 6 was also investigated for activity against other kinetoplastid organisms in multiple developmental life stages including Leishmania donovani (promastigote and amastigote), T. brucei brucei (procyclic and bloodstream), and T. cruzi (epimastigote and amastigote), ${ }^{16}$ with the findings prompting further mode of action studies in $L$. donovani. Compound $\mathbf{8}$, the $R$-enantiomer of 6, was shown to be more effective than the $S$-enantiomer in an in vivo model of visceral leishmaniasis. ${ }^{16}$ Recently, an $\mathrm{NAD}(\mathrm{P}) \mathrm{H}$ oxidase was identified as the activating nitroreductase (NTR2) for the nitroimidazo-oxazole/-oxazine. ${ }^{17}$ However, the monocyclic sulfone metabolite of 4 , known to be activated by a type I nitroreductase, ${ }^{18}$ was only marginally activated by NTR2. ${ }^{17}$ These results support the hypothesis that 6 is activated by an alternative mechanism of action in $L$. donovani under these culture conditions and illustrates the biological complexity of the mode of action of various nitroimidazoles.

In the course of developing $\mathbf{5}$ and $\mathbf{6}$ as treatments for TB, over 1000 derivatives were prepared. ${ }^{19}$ The structure-activity relationships (SARs) disclosed to date mostly include compounds with modifications to the aryl side chain, with a smaller number of variants that alter the bicyclic core structure (Figure 2A). The nitro group and stereochemistry of the side chain have been shown to be critical for activity as both $\mathbf{8}$ and $S$-des-nitro-PA-824 (9) derivatives were inactive in in vitro cultures at $50 \mu \mathrm{M} .{ }^{16}$ An analogue with the nitro group at the $3^{\prime}$ position was also shown to be inactive, clarifying that the $2^{\prime}$ position of the nitro group on the 6 bicyclic scaffold is important for activity. ${ }^{20}$ Replacement of the benzylic oxygen with nitrogen led to an amino-linked series $(\mathbf{1 0 a}-\mathbf{b})$ with favorable in vitro activity and solubility properties. ${ }^{21,22}$ Modification of the imidazole ring to a pyrazole (11a) or triazole (11b) was detrimental to M. tuberculosis activity, as was
A<smiles></smiles><smiles>O=[N+]([O-])c1cc2n(c1)CC(Oc1ccc(OC(F)(F)F)cc1)CO2</smiles>

DNDI-8219 12

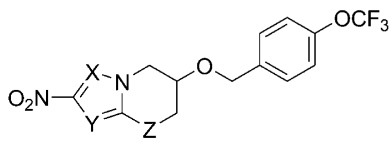

$\mathrm{X}=\mathrm{N}, \mathrm{Y}=\mathrm{CH}, \mathrm{Z}=\mathrm{O}$ $\mathrm{X}=\mathrm{N}, \mathrm{Y}=\mathrm{N}, \mathrm{Z}=\mathrm{O} \quad 11 \mathrm{~b}$ $\mathrm{X}=\mathrm{CH}, \mathrm{Y}=\mathrm{N}, \mathrm{Z}=\mathrm{SO} \quad 11 \mathrm{c}$ $\mathrm{X}=\mathrm{CH}, \mathrm{Y}=\mathrm{N}, \mathrm{Z}=\mathrm{SO}_{2}$ 111 $\mathrm{X}=\mathrm{CH}, \mathrm{Y}=\mathrm{N}, \mathrm{Z}=\mathrm{NH} \quad 11 \mathrm{e}$ $\mathrm{X}=\mathrm{CH}, \mathrm{Y}=\mathrm{N}, \mathrm{Z}=\mathrm{CH}_{2} \quad 11 \mathrm{f}$ $\mathrm{X}=\mathrm{CH}, \mathrm{Y}=\mathrm{N}, \mathrm{Z}=\mathrm{S} \quad 11 \mathrm{~g}$

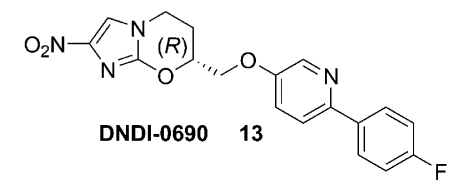<smiles>[Y]c1ccc(COC2Cn3cc([N+](=O)[O-])nc3S(=O)(=O)C2)cc1</smiles>
$\mathrm{n}=1, \mathrm{X}=\mathrm{CH}, \mathrm{Y}=\mathrm{OCH}_{2} \mathrm{Ph}$ $\mathrm{n}=2, \mathrm{X}=\mathrm{CH}, \mathrm{Y}=\mathrm{OCH}_{2} \mathrm{Ph}$ $\mathrm{n}=1, \mathrm{X}=\mathrm{CH}, \mathrm{Y}=\mathrm{OCF}_{3}$

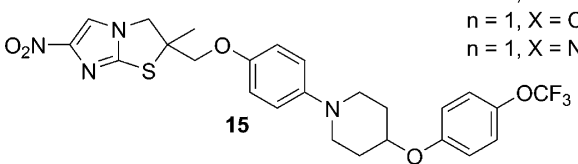

B<smiles>[R]NC(=O)c1nc([N+](=O)[O-])c[nH]1</smiles><smiles>[R]NC(=O)c1nc([N+](=O)[O-])cn1CCC</smiles>

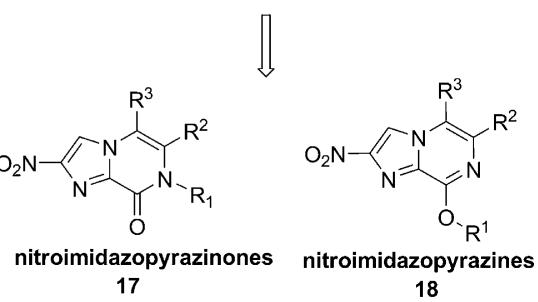

Figure 2. (A) Structural variation of bicyclic nitroimidazoles described in the literature and (B) novel nitroimidazopyrazinones and nitroimidazopyrazines developed by cyclizing the 4(5)-nitroimidazole framework, described here. 
Scheme 1. Synthesis of Nitroimidazopyrazin-ones/-es $17 \mathrm{a}-\mathrm{t}, 18 \mathrm{i}$, and $18 \mathrm{~m}$ by Route (1) Condensation and Dehydration via Nitroimidazole Carboxamide Intermediates or Route (2) Alkylation of $17 a^{a}$

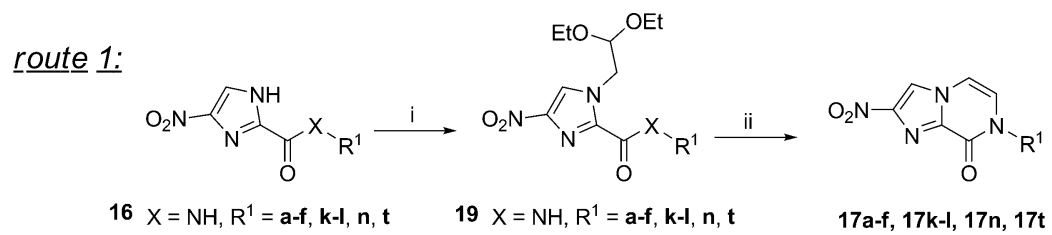

route 2

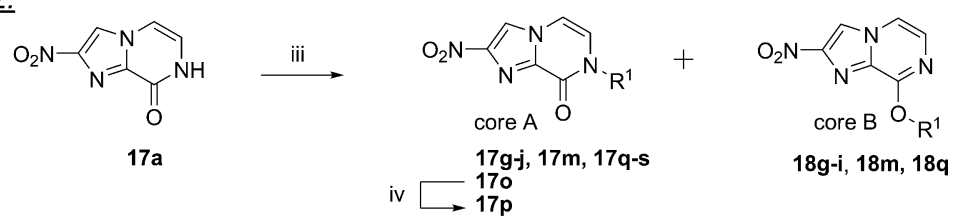

\begin{tabular}{|c|c|c|c|c|c|}
\hline \\
\hline \multicolumn{6}{|r|}{$=\mathrm{CH}_{2} \mathrm{CH}_{2} \mathrm{OAc}$} \\
\hline \\
\hline \multicolumn{6}{|r|}{$\begin{array}{l}=\mathrm{CH}_{2} \mathrm{CH}_{2} \mathrm{OAc} \\
=\mathrm{CH}_{2} \mathrm{CH}_{2} \mathrm{OH} \\
=\mathrm{CH}_{2} \mathrm{CH}_{2}-\text { morpholine }\end{array}$} \\
\hline \multirow{2}{*}{$\begin{array}{l}\text { d } \\
\text { e }\end{array}$} & $=\mathrm{CH}_{2}\left(4-\mathrm{CH}_{3}-\mathrm{Ph}\right)$ & k & $=\mathrm{CH}_{2}(2$-pyridyl $)$ & $\mathbf{r}$ & $=\mathrm{CH}_{2} \mathrm{C}(\mathrm{O})$-morpholine \\
\hline & $=\mathrm{CH}_{2}(4-\mathrm{F}-\mathrm{Ph})$ & i & $=\mathrm{CHMe}(4-\mathrm{F}-\mathrm{Ph})$ & s & $=\mathrm{CH}_{2} \mathrm{C}(\mathrm{O})-\mathrm{NH}_{2}$ \\
\hline \multirow{2}{*}{$\begin{array}{l}f \\
g\end{array}$} & $=\mathrm{CH}_{2}\left(3-\mathrm{OCF}_{3}-\mathrm{Ph}\right)$ & m & $=\mathrm{CH}_{2} \mathrm{CH}_{2}\left(4-\mathrm{OCF}_{3}-\mathrm{Ph}\right)$ & $\mathbf{t}$ & = cyclohexyl \\
\hline & $=\mathrm{CH}_{2}\left(3-\mathrm{CH}_{3}-\mathrm{Ph}\right)$ & $\mathbf{n}$ & $=\mathrm{CH}_{2} \mathrm{CH}_{2}\left(4-\mathrm{CH}_{3}-\mathrm{Ph}\right)$ & & \\
\hline
\end{tabular}

${ }^{a}$ (i) Bromoacetaldehyde diethyl acetal, $\mathrm{K}_{2} \mathrm{CO}_{3}, \mu \mathrm{W} 150-180{ }^{\circ} \mathrm{C}, 69 \%$-quant. yield, (ii) $2 \mathrm{M}$ aq $\mathrm{HCl}\left(10\right.$ vol), 1,4 -dioxane (10 vol), $\mu \mathrm{W} 120{ }^{\circ} \mathrm{C}$, 42-87\%, (17a: 5\% aq HCl, reflux, 66\%); (iii) alkyl/benzyl halide, $\mathrm{K}_{2} \mathrm{CO}_{3} / \mathrm{Cs}_{2} \mathrm{CO}_{3}$, DMF, rt- $\mu \mathrm{W} 120{ }^{\circ} \mathrm{C}$ or $\mathrm{Ag}_{2} \mathrm{CO}_{3} /$ toluene, $80{ }^{\circ} \mathrm{C}$ as detailed in the experimental, 3-84\%, and (iv) $\mathrm{K}_{2} \mathrm{CO}_{3}, \mathrm{MeOH}$, rt, 45\%. Compounds $\mathbf{1 8 g}-\mathbf{h}$ and $\mathbf{1 8 q}$ were detected but not isolated in pure form.

replacement of the oxygen heteroatom in the oxazine ring with sulfoxide (11c), sulfone (11d), amino (11e), or methylene (11f) groups, although a sulfur $(\mathbf{1 1 g})$ heteroatom in the ring was tolerated. $^{23}$

More recent efforts have explored the activity of bicyclic nitroimidazoles against the kinetoplastids Leishmania and trypanosomes. $\mathrm{DND} i$ is currently investigating additional nitroimidazooxazines for development against visceral leishmaniasis, ${ }^{24}$ including DNDI-8219 (12) and DNDI-0690 (13), 6and 7-substituted nitroimidazooxazines, as two promising backup candidates. ${ }^{25,26}$ Interestingly, nitroimidazothiazine oxides $\mathbf{1 4 a}-\mathbf{d}$ were found to display favorable activity against T. $b$. brucei, an animal infective strain that is commonly used as a model of HAT. ${ }^{19}$ Moreover, a "thio-delamanid" derivative (15) proved to be efficacious against T. cruzi, although it was inactive against Leishmania. ${ }^{27}$ These studies demonstrate that the selectivity profile toward different parasites can be altered by structural modifications of the bicyclic scaffold and that different subclasses of the bicyclic nitroimidazoles expand the potential therapeutic scope of this antimicrobial class.

We reasoned that bicyclic nitroimidazole derivatives could have potential against an even wider range of organisms than Leishmania and trypanosomes. Previously, we found that 4(5)nitroimidazoles $(\mathbf{1 6})^{28}$ had potent activity against Giardia lamblia, Entamoeba histolytica, Trichomonas vaginalis, and Clostridium difficile (Figure 2B), and therefore, it was hypothesized that 6 might also have activity against these organisms. Anaerobic protozoa such as G. lamblia and E. histolytica and the anaerobic bacteria $C$. difficile occupy the gut under reduced oxygen tension and cause diarrheal infections. These organisms spread by the fecal oral route through stable cyst forms for the protozoa or through spores for C. difficile. Metronidazole 1 can be used therapeutically for infections caused by these organisms, but alternative treatment options are desirable. Furthermore, cyclizing the 4(5)-nitroimidazoles 16 from the $1^{\prime}$ imidazole ring position to the carboxamide nitrogen could produce new bicyclic nitroimidazopyrazinone/-e scaffolds. These could potentially extend the spectra of biological activity to include $M$. tuberculosis and result in altered SARs against a panel of parasitic organisms. Previous studies have shown that compounds containing the imidazopyrazinone scaffold have a range of different biological activities, including agonism of the $\mathrm{GABA}_{\mathrm{A}}$ receptor, ${ }^{29}$ antagonism of the ionotropic transmembrane receptor, ${ }^{30,31}$ modulation of ion channels to control arrhythmia, ${ }^{32}$ and inhibition of $M$. tuberculosis glutamine synthetase. ${ }^{33}$ However, no studies have investigated the antimicrobial activity of a nitrated derivative of this class.

We now report the findings from an evaluation of $\mathbf{6}$ against a wide range of organisms, and the subsequent design, synthesis, and biological evaluation of novel bicyclic nitroimidazoles, nitroimidazopyrazinones (17) and nitroimidazopyrazines (18) (Figure 2B), derived from the 4(5)-nitroimidazole scaffold 16 previously reported. ${ }^{28}$ Given the potential for activity against many different organisms, compounds were screened against a wide range of microorganisms including: G. lamblia, $E$. histolytica, T. b. brucei, L. donovani, M. tuberculosis, C. difficile, Cryptococcus neoformans, Candida albicans, and representative ESKAPE bacteria: Escherichia coli, Staphylococcus aureus, Klebsiella pneumoniae, Pseudomonas aeruginosa, and Acinetobacter baumannii. Derivatives were counter-screened for cytotoxicity against mammalian liver and kidney cell lines. Preferred derivatives with favorable antimicrobial or antiparasitic activity were then evaluated for therapeutic properties including metabolic stability, plasma protein binding (PPB), and intestinal permeability. Most of the compounds were also assessed for aqueous kinetic solubility. This report presents the first description of SARs and evaluation of nitroimidazopyrazin-ones/-es for antimicrobial and antiparasitic activity with therapeutic potential. 


\section{CHEMISTRY}

Design and Synthesis of Bicyclic Nitroimidazoles with Variation at $\mathbf{R}^{1}, \mathbf{R}^{2}=\mathbf{R}^{3}=\mathbf{H}$. In previous work, ${ }^{28}$ a set of amide-substituted monocyclic nitroimidazoles were prepared, and it was hypothesized for this study that linking the amide and imidazole nitrogen could form a bicyclic nitroimidazopyrazinone system, similar to the pretomanid 6 core (Figure 2B). A library of nitroimidazopyrazinones $17 \mathbf{a}-\mathbf{t}$ were prepared with different functional groups at $\mathrm{R}^{1}$ designed to explore a range of physicochemical properties (Scheme 1). Initial biological results indicated that benzylic $\mathrm{R}^{1}$ groups were favorable for antimicrobial and antiparasitic activity. The library was therefore tailored to contain analogues with a number of different benzyl substituted $R^{1}$ groups $(\mathbf{1 7} \mathbf{b}-\mathbf{j})$, including derivative $17 \mathrm{c}$ with a $4-\mathrm{OCF}_{3}$-substituted benzyl group similar to pretomanid, and analogues with substitutions at the $3^{\prime}$ and $2^{\prime}$ positions. Compound $\mathbf{1 7} \mathbf{k}$ was prepared with $\mathrm{R}^{1}=\mathrm{CH}_{2}$-(2-pyridyl) to introduce a hydrogen bond acceptor and to impart more polarity and improve aqueous solubility. A methyl group was introduced at the benzylic position (17l) to increase the lipophilicity, bulk, and potentially restrict the conformation of the side chain. Two phenethylene derivatives $(17 \mathbf{m}-\mathbf{n})$ were prepared to investigate the effect of spacing the aromatic ring further from the bicyclic core. Derivatives with polar side chain $\mathrm{R}^{1}$ groups were also synthesized, including ethyl acetate $17 \mathrm{o}$, ethyl hydroxyl $17 \mathrm{p}$, morpholine derivatives $17 q-r$, and the carboxamide group $(17 s)$. Compound $17 t$ with $\mathrm{R}^{1}=$ cyclohexyl group was prepared to investigate the effect of a bulky aliphatic group at this position.

Initially, nitroimidazopyrazinones $17 \mathbf{a}-\mathbf{f}, 17 \mathrm{k}-\mathbf{l}, 17 \mathrm{n}$, and $17 \mathrm{t}$ were prepared from 4(5)-nitroimidazole carboxamides $16 \mathrm{a}-\mathrm{f}, 16 \mathrm{k}-\mathrm{l}, 16 \mathrm{n}$, and $16 \mathrm{t}^{28}$ by cyclizing the $1^{\prime}$ imidazole to the $2^{\prime}$ free amide nitrogen (route 1 , Scheme 1). This was achieved by alkylating 4(5)-nitroimidazoles with bromoacetaldehyde diethyl acetal under basic conditions $\left(\mathrm{K}_{2} \mathrm{CO}_{3}\right)$ which strongly favored the 4-nitro regioisomer product. ${ }^{34}$ Second, microwave heating $\left(\mu \mathrm{W} 120{ }^{\circ} \mathrm{C}\right)$ of $19 \mathrm{a}-\mathbf{f}, 19 \mathrm{k}-\mathbf{l}, 19 \mathrm{n}$, and $19 t$ under acidic conditions afforded the bicyclic products $17 \mathbf{a}-\mathbf{f}, 17 \mathbf{k}-\mathbf{l}, 17 \mathbf{n}$, and $17 \mathrm{t}$. This synthesis was based on the preparation of des-nitro-imidazopyrazinone 20a, as previously described by Prévot and Leumann; ${ }^{35}$ however, microwave heating at higher temperatures and for shorter periods than conventional reflux facilitated analogue generation for both steps. Second, inclusion of a cosolvent (aq $2 \mathrm{M} \mathrm{HCl} / 1,4-$ dioxane 1:1) was necessary to solubilize the secondary amide starting material and achieve conversion to the desired products $17 \mathbf{b}-\mathbf{f}, 17 \mathbf{k}-\mathbf{l}, 17 \mathrm{n}$, and $17 \mathrm{t}$. With this approach, products often precipitated from the reaction mixture and could be isolated in high purity by filtration and washes $\left(\mathrm{H}_{2} \mathrm{O}\right)$ alone, especially if the intermediate had been purified by chromatography. Alternatively, the products were purified by recrystallization. In the ${ }^{1} \mathrm{H} N \mathrm{NR}$, the imidazopyrazinone $\mathrm{R}^{2}$ and $\mathrm{R}^{3}$ proton groups were typically two doublets $(J=\sim 5.9$ $\mathrm{Hz}$ ), each integrating for 1 proton at $\sim \delta 7.4 \mathrm{ppm}$ and $\sim \delta 7.6$ ppm, respectively. Furthermore, both NMR (2D HMBC) experiments and an X-ray crystal structure of 17a confirmed the 2-position of the nitro group (Supporting Information, Figure S1).

A second approach to prepare bicyclic nitroimidazoles $17 \mathrm{~g}-$ $\mathrm{j}, 17 \mathrm{~m}, 17 \mathrm{o}$, and $17 \mathrm{q}-\mathrm{s}$ was developed as shown in route 2 , Scheme 1. This method was more convergent as it eliminated the need to prepare 4(5)-nitroimidazole intermediates of each derivative. Route 2 involved alkylation of 17 a with alkyl/aryl halides under basic conditions (carbonate base) to form $17 \mathrm{~g}-$ j, $17 \mathbf{m}, 17 \mathrm{o}$, and $17 \mathbf{q}-\mathbf{s}$. This approach also produced the minor O-alkylated regioisomer in some cases. This was considered advantageous because the alternative pyrazine ring was anticipated to have different biological activities and properties. In all cases, use of $\mathrm{K}_{2} \mathrm{CO}_{3}$ or $\mathrm{Cs}_{2} \mathrm{CO}_{3}$ in dimethylformamide (DMF) resulted in $>10: 1$ ratio of the pyrazinone to pyrazine derivatives. Reaction with $\mathrm{Ag}_{2} \mathrm{CO}_{3}$ in toluene and heating as described in the literature ${ }^{36,37}$ was briefly explored and found to increase the ratio of the minor imidazopyrazine isomer, with pyrazinone/pyrazine ratios of $2: 1$ for $17 \mathrm{~g} / 18 \mathrm{~g}$ and $17 \mathrm{i} / \mathbf{1 8 i}$. Unfortunately, the $\mathrm{Ag}_{2} \mathrm{CO}_{3} /$ toluene method resulted in unreacted starting material and a greater number of side products compared to $\mathrm{K}_{2} \mathrm{CO}_{3}$ or $\mathrm{Cs}_{2} \mathrm{CO}_{3}$ in DMF. This complicated the separation of $\mathbf{1 8 g}$ to the required $>95 \%$ purity for biological assay. Therefore, isomers $17 \mathbf{m}$ and $18 \mathrm{~m}$ were prepared using $\mathrm{K}_{2} \mathrm{CO}_{3}$ in DMF.

Nitroimidazopyrazines were readily distinguished from nitroimidazopyrazinones as they were more lipophilic, and thus were more strongly retained on $\mathrm{C} 18$ silica and more weakly retained on normal phase silica. Furthermore, in the ${ }^{1} \mathrm{H}$ $\mathrm{NMR}$, the resonance due to the $\mathrm{OCH}_{2}$ of $18 \mathrm{i}$ and $18 \mathrm{~m}$ was 0.4-0.6 ppm further downfield than the corresponding resonance due to the $\mathrm{NCH}_{2}$ group in the pyrazinone scaffold (e.g., 18i/17i $\delta 5.64$ vs $5.21 \mathrm{ppm}$ ). In the ${ }^{13} \mathrm{C}$ NMR spectrum, the corresponding $\mathrm{O}_{\mathrm{CH}} \mathrm{H}_{2}$ resonance was also shifted 17-19 ppm downfield for $\mathbf{1 8 i}$ and $\mathbf{1 8 m}$ compared to the corresponding $\mathrm{NCH}_{2}$ resonance (e.g., 18i/17i $\delta 62.7$ vs 45.7 $\mathrm{ppm})$.

Des-Nitro Derivatives. Des-nitro derivatives $20 \mathrm{~b}-\mathrm{c}$ were prepared as negative control compounds, essentially as described for the nitrated series above (Scheme 2). It was hypothesized that these compounds should be biologically inactive if the parent compounds had a mechanism of action involving reduction of the nitro group.

Scheme 2. Synthesis of Des-nitro Imidazopyrazinones 20b$c^{a}$

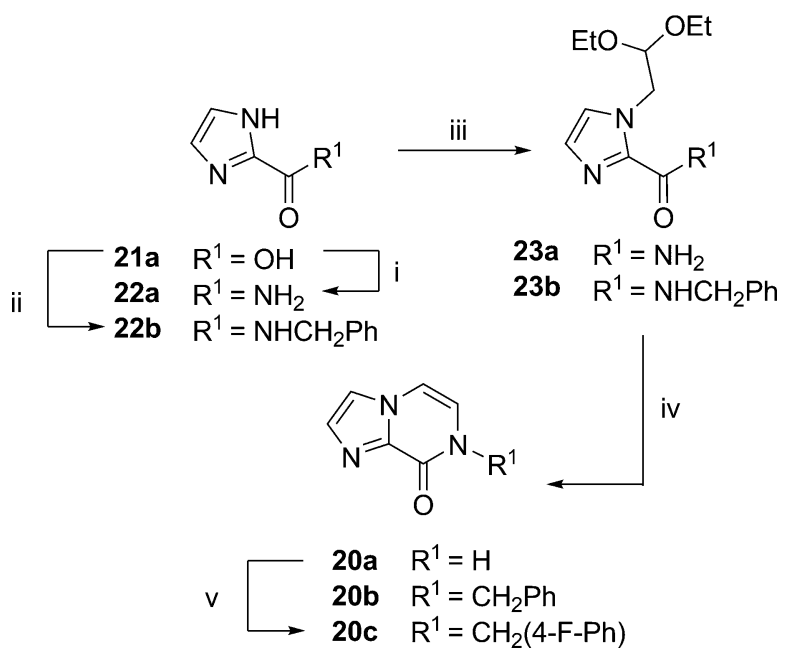

${ }^{a}$ (i) $(\mathrm{COCl})_{2}$, cat. DMF, DCM, $0{ }^{\circ} \mathrm{C} \rightarrow \mathrm{rt}$, then conc. $\mathrm{NH}_{4} \mathrm{OH}$, $73 \%{ }^{28}$ (ii) $\mathrm{SOCl}_{2}$, reflux, then benzyl amine, 69\%; (iii) bromoacetaldehyde diethyl acetal, $\mathrm{K}_{2} \mathrm{CO}_{3}, \mu \mathrm{W} 120-180{ }^{\circ} \mathrm{C}, 81-92 \%$; (iv) for 20a: $5 \%$ aq $\mathrm{HCl}$, reflux, $50 \%$; for 20 b: $5 \%$ aq $\mathrm{HCl}, 80^{\circ} \mathrm{C}$, $39 \%$; (v) 4fluorobenzylamine, $\mathrm{K}_{2} \mathrm{CO}_{3}$, DMF, rt, $19 \%$. 
Design and Synthesis of Nitroimidazopyrazin-ones/es with Modifications at $\mathbf{R}^{2}, \mathbf{R}^{3}$. We then explored different variations at the $R^{2}$ and $R^{3}$ positions, established a shortened route to synthesize the nitroimidazopyrazinone core, and further investigated the activity of the nitroimidazopyrazine scaffold (Scheme 3). Both core scaffolds were prepared with

Scheme 3. Synthesis of Nitroimidazopyrazinon-one/-es $24 a-e, 25 a-m$, and $26 a-i$ with Variations at $R^{2}$ and $R^{3 a}$<smiles>[R]Oc1nc([R])c2nc([N+](=O)[O-])cn2c1[R]</smiles>

\begin{tabular}{|c|c|c|c|}
\hline \multicolumn{3}{|c|}{ core $\underline{A}$ core $\underline{B}$} & \\
\hline \multicolumn{4}{|c|}{$\mathrm{R}_{2}=\mathrm{Ph}, \mathrm{R}_{3}=\mathrm{H}$} \\
\hline $24 b$ & $24 c$ & $\mathrm{R}_{1}=\mathrm{CH}_{2} \mathrm{OAc}$ & \\
\hline 24d & $24 \mathrm{e}$ & $\mathrm{R}_{1}=\mathrm{CH}_{2} \mathrm{OH}$ & \\
\hline \multicolumn{4}{|c|}{$\mathrm{R}_{2}=\mathrm{CH}_{3}, \mathrm{R}_{3}=\mathrm{H}$} \\
\hline $25 b$ & $25 c$ & $\mathrm{R}_{1}=\mathrm{CH}_{2} \mathrm{OAC}$ & \\
\hline $25 d$ & $25 \mathbf{e}$ & $\mathrm{R}_{1}=\mathrm{CH}_{2} \mathrm{OH}$ & \\
\hline $25 f$ & $25 \mathrm{~g}$ & $\mathrm{R}_{1}=\mathrm{CH}_{2}(4-\mathrm{OCF}$ & $\left.={ }_{3}-\mathrm{Ph}\right)$ \\
\hline $25 \mathrm{~h}$ & $25 i$ & $\mathrm{R}_{1}=\mathrm{CH}_{2}\left(4-\mathrm{CH}_{3}\right.$ & $-\mathrm{Ph})$ \\
\hline $25 \mathrm{j}$ & $25 \mathrm{k}$ & $\mathrm{R}_{1}=\mathrm{CH}_{2}(3-\mathrm{OCF}$ & $\left.={ }_{3}-\mathrm{Ph}\right)$ \\
\hline 251 & $25 m$ & $\mathrm{R}_{1}=\mathrm{CH}_{2}(2-\mathrm{OCF}$ & $\left.={ }_{3}-\mathrm{Ph}\right)$ \\
\hline \multicolumn{4}{|c|}{$\mathrm{R}_{2}=\mathrm{CH}_{3}, \mathrm{R}_{3}=\mathrm{CH}_{3}$} \\
\hline 26b & $26 c$ & $\mathrm{R}_{1}=\mathrm{CH}_{2}(4-\mathrm{OCF}$ & $\left.={ }_{3}-\mathrm{Ph}\right)$ \\
\hline 26d & $26 e$ & $\mathrm{R}_{1}=\mathrm{CH}_{2}\left(4-\mathrm{CH}_{3}\right.$ & $-\mathrm{Ph})$ \\
\hline $26 f$ & $26 \mathrm{~g}$ & $\mathrm{R}_{1}=\mathrm{CH}_{2}(3-\mathrm{OCF}$ & $\left.={ }_{3}-\mathrm{Ph}\right)$ \\
\hline $26 \mathrm{~h}$ & $26 i$ & $\mathrm{R}_{1}=\mathrm{CH}_{2}(2-\mathrm{OCF}$ & $=3-\mathrm{Ph})$ \\
\hline
\end{tabular}

${ }^{a}$ (i) 2-Bromoacetophenone, $\mathrm{K}_{2} \mathrm{CO}_{3}, \mathrm{DMF}, \mathrm{rt}, 60 \%$; (ii) $2 \mathrm{M} \mathrm{HCl}, 1,4-$ dioxane, $\mu \mathrm{W} 120{ }^{\circ} \mathrm{C}$, 84\%; (iii) 25a \& 26a: $\alpha$-halo ketone, $\mathrm{K}_{2} \mathrm{CO}_{3}$, DMF, rt; (iv) 25a \& 26a: $2 \mathrm{M} \mathrm{HCl}$, 1,4-dioxane, rt, 40-67\% over two steps; (v) $\mathrm{K}_{2} \mathrm{CO}_{3}$ or $\mathrm{Cs}_{2} \mathrm{CO}_{3}, \mathrm{DMF}, \mathrm{rt}-\mu \mathrm{W} 80{ }^{\circ} \mathrm{C}, 41-90 \%$ yield inclusive of both isomers; (vi) $\mathrm{K}_{2} \mathrm{CO}_{3}, \mathrm{MeOH}, \mathrm{rt}, 10-83 \%$ yield. Compound 25k was detected but not isolated.

three different combinations of $\mathrm{R}^{2}$ and $\mathrm{R}^{3}$ groups in order to assess how functionalization at these sites could affect activity against different organisms. Because benzyl groups at $\mathrm{R}^{1}$ were favorable for biological activity, derivatives $24 \mathrm{a}-\mathrm{e}$ containing $\mathrm{R}^{2}=\mathrm{Ph}$ and $\mathrm{R}^{3}=\mathrm{H}$, but including polar substituents $\left(\mathrm{CH}_{2} \mathrm{CH}_{2} \mathrm{OAc}\right.$ or $\left.\mathrm{CH}_{2} \mathrm{CH}_{2} \mathrm{OH}\right)$ at $\mathrm{R}^{1}$ to counteract the increase in compound lipophilicity, were prepared. The effect of a methyl group at $\mathrm{R}^{2}=\mathrm{CH}_{3}$, as a small, nonpolar substituent (derivatives $25 \mathbf{a}-\mathbf{m}$ ) was also assessed. For the series with $\mathrm{R}^{2}$ $=\mathrm{CH}_{3}$, both polar and nonpolar substituents at $\mathrm{R}^{1}$, including $\mathrm{R}^{1}=\mathrm{CH}_{2} \mathrm{CH}_{2} \mathrm{OAc}, \mathrm{CH}_{2} \mathrm{CH}_{2} \mathrm{OH}$, and several preferred benzyl derivatives were investigated. Lastly, matched pair analogues with $\mathrm{R}^{2}=\mathrm{R}^{3}=\mathrm{CH}_{3}(\mathbf{2 6} \mathbf{a}-\mathbf{i})$ with the preferred benzyl substituents at $\mathrm{R}^{1}$ were prepared.

The synthesis of the nitroimidazopyrazinone $24 a\left(R^{2}=P h\right)$ was initially performed as in Scheme 3 in a similar manner as described earlier. Intermediate 16a was alkylated with 2bromoacetophenone at room temperature with $\mathrm{K}_{2} \mathrm{CO}_{3}$ as a base catalyst to yield $27 \mathrm{a}$, which was then purified by silica chromatography. The condensation-dehydration cyclization of 27a was achieved with $2 \mathrm{M}$ aq $\mathrm{HCl}$ and 1,4-dioxane under microwave irradiation to form the phenyl substituted nitroimidazopyrazinone core $\mathbf{2 4 a}$. To synthesize the nitroimidazopyrazinone cores with $\mathrm{R}^{2}=\mathrm{CH}_{3}(\mathbf{2 5 a})$ and $\mathrm{R}^{2}=\mathrm{R}^{3}=\mathrm{CH}_{3}$ (26a), a more concise synthesis was designed that involved a two-step, one-pot tandem alkylation-dehydration reaction (Scheme 3). For 25a and 26a, this procedure worked well. The conditions were mild as both steps of the reaction (alkylation and condensation-dehydration) proceeded at room temperature and the products were obtained in high purity after filtration and washes $\left(\mathrm{H}_{2} \mathrm{O}\right.$ and $\left.\mathrm{MeOH}\right)$ of the precipitate (67\% yield over two steps). The one pot, two-step methodology was also tested for $24 a\left(\mathrm{R}^{2}=\right.$ phenyl $)$, although conversion and yields were reduced [ $40 \%$ isolated yield with product of $57 \%$ purity: Abs \% UV $254 \mathrm{~nm}$ liquid chromatography-mass spectrometry (LCMS)] due to impurities that formed in both steps because of the different reactivity of the alkylation and condensation-dehydration steps. In addition, product $24 \mathbf{a}$ was slightly soluble in the methanol used in the wash step to remove more nonpolar impurities. An intermediate work-up procedure or optimization of the initial alkylation conditions could be explored to improve this method for 24a.

Alkylation of nitroimidazopyrazinones 24a, 25a, and 26a under basic conditions provided both the $\mathrm{N}$ - and O-alkylated constitutional isomers that were readily separated by chromatography. Alkylation conditions that used heating in the presence of $\mathrm{Cs}_{2} \mathrm{CO}_{3}$ generally favored the O-alkylated nitroimidazopyrazine product. The method employed here was sufficient to provide both possible isomers for biological evaluation, but further optimization of the reaction conditions could be explored in the future to alter the ratio of $\mathrm{N}$ - to $\mathrm{O}$ alkylated product. ${ }^{38}$ Again, the acetate groups were removed using $\mathrm{K}_{2} \mathrm{CO}_{3} / \mathrm{MeOH}$ to give the nitroimidazopyrazin-ones/-es 24d-e and $25 \mathrm{~d}-\mathrm{e}$.

\section{RESULTS AND DISCUSSION}

Antiparasitic and Antimicrobial Activity of Pretomanid. Both pretomanid 6 and its enantiomer 8 were found to be $\sim 2$-fold more active than metronidazole 1 against G. lamblia (Table 1). Both enantiomers also had activity against $E$. histolytica, with 8 active at comparable levels to 1 , and $6 \sim 2$ fold less active than 1. Compound 6 had moderate activity against $C$. difficile ( $\mathrm{MIC}=4 \mu \mathrm{g} / \mathrm{mL})$, which was 8-fold less potent than metronidazole 1 ( $\mathrm{MIC}=0.5 \mu \mathrm{g} / \mathrm{mL})$ (Table 1$)$. These results expand the spectrum of action of $\mathbf{6}$, which was previously described to inhibit $M$. tuberculosis, Leishmania spp., and Trypanosoma spp. ${ }^{16,26}$ The enantiomers $6 / 8$ have been reported to have more significant differences in activities against $L$. donovani, trypanosomes, and $M$. tuberculosis. ${ }^{16}$ For 
Table 1. Activity of Pretomanid (6) Against Enteric Pathogens

\begin{tabular}{|c|c|c|c|}
\hline \multirow[b]{2}{*}{ compound } & \multicolumn{2}{|c|}{ antiparasitic $\mathrm{IC}_{50}(\mu \mathrm{M})\left(\mathrm{pIC}_{50} \pm \mathrm{SE}\right)$} & \multirow{2}{*}{$\frac{\text { antibacterial MIC }(\mu \mathrm{g} / \mathrm{mL})}{\text { C. difficile }}$} \\
\hline & G. lamblia & E. histolytica & \\
\hline metronidazole (1) & $7.2(5.1 \pm 0.02)$ & $4.3(5.4 \pm 0.02)$ & 0.5 \\
\hline pretomanid (6) & $3.0(5.5 \pm 0.02)$ & $9.3(5.0 \pm 0.03)$ & 4 \\
\hline (R)-PA-824 (8) & $3.2(5.5 \pm 0.08)$ & $5.3(5.3 \pm 0.08)$ & N.D. \\
\hline
\end{tabular}

Table 2. Activity of Nitroimidazopyrazinones and Nitroimidazopyrazines with Variation at $\mathbf{R}^{1}, \mathbf{R}^{2}=\mathbf{R}^{3}=\mathbf{H}$

\begin{tabular}{|c|c|c|c|c|c|c|c|}
\hline \multicolumn{3}{|c|}{ compound } & $\begin{array}{l}\text { molecular weight } \\
(\mathrm{g} / \mathrm{mol})\end{array}$ & \multicolumn{2}{|c|}{ antibacterial MIC $(\mu \mathrm{g} / \mathrm{mL})$} & \multicolumn{2}{|c|}{ antiparasitic $\mathrm{IC}_{50}(\mu \mathrm{M})\left(\mathrm{pIC}_{50} \pm \mathrm{SE}\right)^{d}$} \\
\hline no. & core & $\mathrm{R}^{1}$ & & $\begin{array}{l}\text { M. tuberculosis } \\
\text { normoxia }\end{array}$ & M. tuberculosis ${ }^{a}$ hypoxia & G. lamblia ${ }^{b}$ & T. b. brucei ${ }^{c}$ \\
\hline \multirow{2}{*}{\multicolumn{3}{|c|}{$\begin{array}{c}\text { metronidazole } 1 \\
\text { pretomanid } 6\end{array}$}} & 171.2 & $>32$ & $>32$ & $7.2(5.1 \pm 0.02)$ & $>40(<4.4)$ \\
\hline & & & 359.3 & $0.25-0.5$ & 1 & $3.0(5.5 \pm 0.02)$ & $19(4.7 \pm 2.4)$ \\
\hline $17 \mathbf{a}$ & A & $\mathrm{H}$ & 180.1 & $>32$ & $>32$ & $>25(<4.6)$ & 97\% I@40 $\mu \mathrm{M}$ \\
\hline $17 \mathrm{~b}$ & A & $\mathrm{CH}_{2} \mathrm{Ph}$ & 270.2 & $0.5-1$ & $4-8$ & $5.0(5.3 \pm 0.05)$ & 73\% I @ $40 \mu \mathrm{M}$ \\
\hline $17 \mathrm{c}$ & A & $\mathrm{CH}_{2}\left(4-\mathrm{OCF}_{3}-\mathrm{Ph}\right)$ & 354.2 & 0.5 & $1-4$ & $3.5(5.5 \pm 0.01)$ & $1.4(5.9 \pm 0.08)$ \\
\hline $17 d$ & A & $\mathrm{CH}_{2}\left(4-\mathrm{CH}_{3}-\mathrm{Ph}\right)$ & 284.3 & 0.125 & $1-4$ & $3.4(5.5 \pm 0.03)$ & $>40(<4.4)$ \\
\hline $17 \mathrm{e}$ & A & $\mathrm{CH}_{2}(4-\mathrm{F}-\mathrm{Ph})$ & 288.2 & 1 & 2 & $6.4(5.2 \pm 0.07)$ & $2.9(5.5 \pm 0.41)$ \\
\hline $17 f$ & A & $\mathrm{CH}_{2}\left(3-\mathrm{OCF}_{3}-\mathrm{Ph}\right)$ & 354.2 & 0.125 & $0.5-2$ & $1.7(5.8 \pm 0.03)$ & 38\% I@16 $\mu \mathrm{M}$ \\
\hline $17 \mathrm{~g}$ & A & $\mathrm{CH}_{2}\left(3-\mathrm{CH}_{3}-\mathrm{Ph}\right)$ & 284.3 & 0.06 & 70-90\% I @0.125-8 $\mu \mathrm{g} / \mathrm{mL}$ & $9.0(5.0 \pm 0.03)$ & $5.4(5.3 \pm 0.23)$ \\
\hline $17 \mathrm{~h}$ & A & $\mathrm{CH}_{2}\left(3-\mathrm{CF}_{3}-\mathrm{Ph}\right)$ & 338.2 & 0.06 & 70-90\% I @0.06-16 $\mu \mathrm{g} / \mathrm{mL}$ & $7.1(5.1 \pm 0.03)$ & $5.3(5.3 \pm 0.18)$ \\
\hline $17 \mathrm{i}$ & A & $\mathrm{CH}_{2}\left(2-\mathrm{OCF}_{3}-\mathrm{Ph}\right)$ & 354.2 & 1 & 8 & $8.2(5.1 \pm 0.03)$ & $6.0(5.2 \pm 1.5)$ \\
\hline $17 \mathbf{j}$ & A & $\mathrm{CH}_{2}(2,4-\mathrm{F}-\mathrm{Ph})$ & 306.2 & $16-32$ & $>32$ & $>50(<4.3)$ & $>40(<4.4)$ \\
\hline $17 \mathbf{k}$ & A & $\mathrm{CH}_{2}$ (2-pyridyl) & 271.2 & $>32$ & $>32$ & $14(4.8 \pm 0.05)$ & $9.7(5.0 \pm 0.18)$ \\
\hline 171 & A & $\mathrm{CHMe}(4-\mathrm{F}-\mathrm{Ph})$ & 302.3 & 0.5 & $4-6.3$ & $2.1(5.7 \pm 0.03)$ & 94\% I@40 $\mu \mathrm{M}$ \\
\hline $17 \mathrm{~m}$ & A & $\mathrm{CH}_{2} \mathrm{CH}_{2}\left(4-\mathrm{OCF}_{3}-\mathrm{Ph}\right)$ & 368.3 & $8^{*}(70 \% \mathrm{I})$ & $>32$ & $1.6(5.8 \pm 0.04)$ & 44\% I@40 $\mu \mathrm{M}$ \\
\hline $17 \mathrm{n}$ & A & $\mathrm{CH}_{2} \mathrm{CH}_{2}\left(4-\mathrm{CH}_{3}-\mathrm{Ph}\right)$ & 298.3 & $4^{*}(78 \% \mathrm{I})$ & $>32$ & $3.2(5.5 \pm 0.04)$ & $>40(<4.4)$ \\
\hline $17 \mathrm{o}$ & A & $\mathrm{CH}_{2} \mathrm{CH}_{2} \mathrm{OAc}$ & 266.2 & $>32$ & $>32$ & $65(4.2 \pm 0.03)$ & $6.5(5.2 \pm 0.22)$ \\
\hline $17 p$ & A & $\mathrm{CH}_{2} \mathrm{CH}_{2} \mathrm{OH}$ & 224.2 & $>32$ & $>32$ & $>50(<4.3)$ & 87\% I@40 $\mu \mathrm{M}$ \\
\hline $17 q$ & A & $\mathrm{CH}_{2} \mathrm{CH}_{2}$-morpholine & 293.3 & $>32$ & $>32$ & $\sim 50(\sim 4.3)$ & $2.9(5.5 \pm 0.14)$ \\
\hline $17 \mathbf{r}$ & A & $\mathrm{CH}_{2} \mathrm{CO}$-morpholine & 307.3 & $>32$ & $>32$ & $>50(<4.3)$ & $4.1(5.4 \pm 6.8)$ \\
\hline $17 \mathrm{~s}$ & A & $\mathrm{CH}_{2} \mathrm{CONH}_{2}$ & 237.2 & $>32$ & $>32$ & $>50(<4.3)$ & $>40(<4.4)$ \\
\hline $17 t$ & A & cyclohexyl & 262.3 & $>32$ & $>32$ & $5.2(5.3 \pm 0.03)$ & $1.4(5.9 \pm 0.13)$ \\
\hline $18 \mathrm{i}$ & $\mathrm{B}$ & $\mathrm{CH}_{2}\left(2-\mathrm{OCF}_{3}-\mathrm{Ph}\right)$ & 354.2 & $>32$ & $>32$ & $12(4.9 \pm 0.05)$ & $>40(<4.4)$ \\
\hline $18 \mathrm{~m}$ & $\mathrm{~B}$ & $\mathrm{CH}_{2} \mathrm{CH}_{2}\left(4-\mathrm{OCF}_{3}-\mathrm{Ph}\right)$ & 368.3 & $>32$ & $>32$ & $5.2(5.3 \pm 0.03)$ & N.D \\
\hline
\end{tabular}

${ }^{a} \mathrm{H} 37 \mathrm{Rv}$, M. tuberculosis-normoxia primary screen at $32 \mu \mathrm{g} / \mathrm{mL} n=3$, M. tuberculosis-hypoxia primary screen at $32 \mu \mathrm{g} / \mathrm{mL} n=1-3$, MIC-normoxia/ hypoxia of active compounds $n=3-6$. Isoniazid control M. tuberculosis-normoxia MIC $=0.04 \mu \mathrm{g} / \mathrm{mL}$, M. tuberculosis-hypoxia MIC $>5 \mu \mathrm{g} / \mathrm{mL}$ ${ }^{b} \mathrm{WB}$. ${ }^{c}$ Pentamidine control $\mathrm{IC}_{50}=0.002 \mu \mathrm{M}\left(\mathrm{pIC}_{50}=8.7\right)$, diminazine aceturate $\mathrm{IC}_{50}=0.062 \mu \mathrm{M}\left(\mathrm{pIC}_{50}=7.2\right)$, puromycin IC ${ }_{50}=0.05 \mu \mathrm{M}$ $\left(\mathrm{pIC}_{50}=7.3\right), n=2 .{ }^{d}$ The percentage inhibition (\% I) at the highest concentration tested is reported for compounds that were not sufficiently active to determine an $\mathrm{IC}_{50}$. *Increasing concentrations of compound did not inhibit growth further.

example, 8 was $\sim 5$-fold more active than 6 against $L$. donovani in both the promastigote and amastigote (intracellular macrophage) assays. ${ }^{16}$ While 6 had weak activity against $T$. cruzi and T. b. brucei in the parasite life stages relevant to mammalian infection, $\mathbf{8}$ had slightly enhanced activity, similar to the results against $L$. donovani. ${ }^{16}$ In contrast, 8 was inactive against M. tuberculosis. ${ }^{39}$ Compound $\mathbf{8}$ has previously been shown to bind to the $M$. tuberculosis Ddn enzyme involved in reductive activation of 6 , but it could not be turned over by the enzyme. ${ }^{39}$ These differences in selectivity of the enantiomers 6 and 8 likely indicate differences in the mode of action, respective targets, or uptake of compound by the respective organisms. Nonetheless, the results suggest that 6 or newer derivatives may also be repurposed toward enteric parasites. More potent compounds could also potentially be identified in the future by screening a library of pretomanid analogues from the TB alliance/DND $i$ collections, given that more than 1000 analogues have been prepared. ${ }^{19}$

SAR of Bicyclic Nitroimidazoles with Variation at $\mathbf{R}^{\mathbf{1}}$, $R^{2}=R^{3}=H$. Given the broad activity of pretomanid 6 , bicyclic nitroimidazoles $17 \mathbf{a}-\mathbf{t}, \mathbf{1 8 i}$, and $18 \mathrm{~m}$ were tested against a wide panel of organisms. These organisms included $M$. tuberculosis grown under aerobic (normoxic) and nonreplicating (hypoxic) conditions, G. lamblia, E. histolytica, L. donovani (intracellular amastigote assay), T. b. brucei, and C. difficile. To gain a clear understanding of the spectra of action, compounds were also screened against representative ESKAPE bacterial pathogens S. aureus (ATCC 43300), E. coli (ATCC 25922), K. pneumoniae (ATCC 700603), A. baumannii (ATCC 19606), and $P$. aeruginosa (ATCC 27853) and fungal pathogens, $C$. albicans (ATCC 90028) and C. neoformans (H99 type strain, ATCC 208821) at the Community for Open Antimicrobial Drug Discovery (CO-ADD). ${ }^{40}$ The cytotoxicity against mammalian liver HepG2 and kidney HEK293 cell lines was also evaluated.

Gratifyingly, several compounds showed potent activity against M. tuberculosis, G. lamblia, and T. b. brucei with the SAR described in Table 2. The $\mathrm{N}$ - and O-alkylated isomers had varying profiles, with the nitroimidazopyrazinones $17 \mathbf{a}-\mathbf{t}$ consistently lacking activity against L. donovani, E. histolytica, 


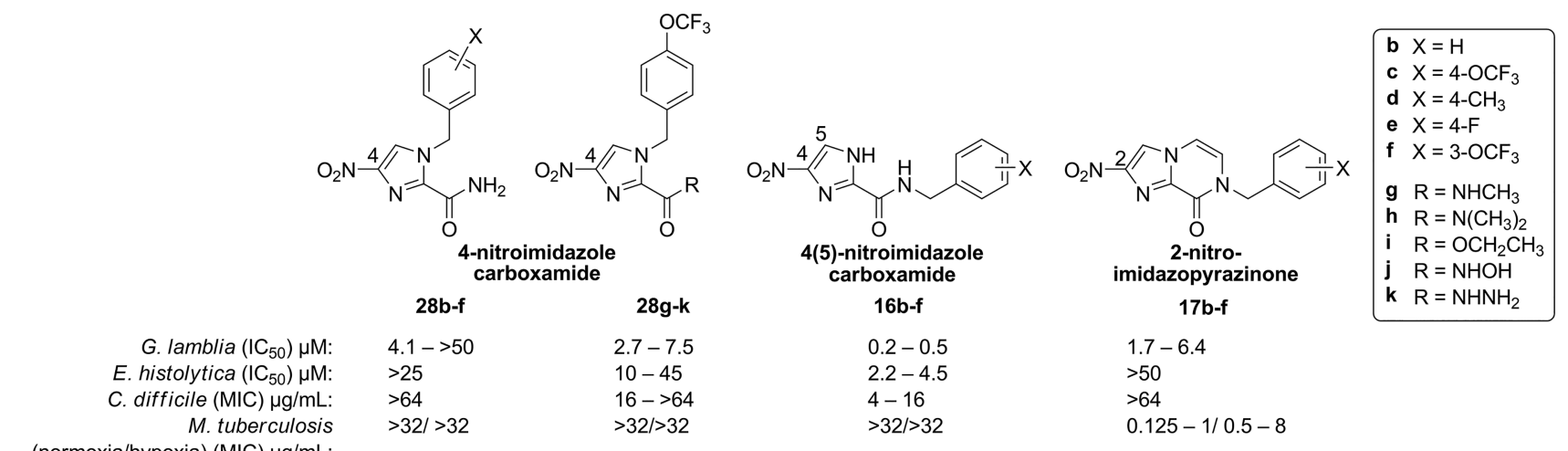

(normoxia/hypoxia) (MIC) $\mu \mathrm{g} / \mathrm{mL}$ :

Figure 3. 4-Nitroimidazoles $\mathbf{2 8 b}-\mathbf{k}$ and $4(5)$-nitroimidazole carboxamide $\mathbf{1 6} \mathbf{b}-\mathbf{f}$, compared to nitroimidazopyrazinones $\mathbf{1 7 b}-\mathbf{f}$.

or C. difficile. However, nitroimidazopyrazine $18 \mathrm{~m}$ was distinguished by its activity against E. histolytica $\left(\mathrm{IC}_{50}=7.8\right.$ $\mu \mathrm{M}$, Supporting Information, Table S5) and also G. lamblia $\left(\mathrm{IC}_{50}=5.2 \mu \mathrm{M}\right)$, despite no activity against $M$. tuberculosis compared to the nitroimidazopyrazinone derivative $17 \mathrm{~m}$. The screen against ESKAPE and fungal pathogens revealed that these compounds were selective for M. tuberculosis, G. lamblia, and $T . b$. brucei as they were not active against the other organisms ( $\mathrm{MIC}>32 \mu \mathrm{g} / \mathrm{mL}$ ) (Supporting Information, Table S5). Importantly, the majority of the compounds were not cytotoxic at the highest concentration tested $\left(\mathrm{CC}_{50}>100 \mu \mathrm{M}\right)$ against mammalian liver HepG2 and kidney HEK293 cell lines (Supporting Information, Table S5). However, compounds 17b $\left(\mathrm{R}^{1}=\mathrm{CH}_{2} \mathrm{Ph}\right)$ and $\mathbf{1 7 t}\left(\mathrm{R}^{1}=\right.$ cyclohexyl $)$ were moderately cytotoxic against mammalian liver and kidney cell lines $\left(\mathrm{CC}_{50}\right.$ $=98-123 \mu \mathrm{M})$ compared to compounds $17 \mathrm{a}$ and $17 \mathrm{c}-\mathrm{s}$ $\left(\mathrm{CC}_{50}>100 \mu \mathrm{M}\right)$. Nitroimidazopyrazine derivatives $\mathbf{1 8 i}$ and $\mathbf{1 8 m}$ were also not cytotoxic against mammalian cell lines $\left(\mathrm{CC}_{50}>100 \mu \mathrm{M}\right)$. This activity profile suggests a specific mechanism of action in M. tuberculosis, G. lamblia, and T. $b$. brucei rather than a general nonspecific toxic effect.

Nitroimidazopyrazinones $\mathbf{1 7} \mathbf{b}-\mathbf{i}$ with a monosubstituted benzyl group at $\mathrm{R}^{1}$ displayed potent activity against $M$. tuberculosis $\left(\mathrm{MIC}_{\text {normoxia }}=0.06-1 \mu \mathrm{g} / \mathrm{mL}\right)$ at levels up to 2 fold better than pretomanid $6\left(\mathrm{MIC}_{\text {normoxia }}=0.25-0.5 \mu \mathrm{g} /\right.$ $\mathrm{mL})$. There was a slight preference for substitution at the $3^{\prime}$ over the $2^{\prime}$ and $4^{\prime}$ positions of the phenyl group (cf. $17 \mathbf{f}-\mathrm{g}$ with $17 \mathbf{i}$ and $17 \mathrm{c}-\mathbf{d}$ ). However, there was otherwise little electronic effect; both electron donating $\left(\mathbf{1 7 g}, \mathrm{R}^{1}=\mathrm{CH}_{2}\right.$ (3$\left.\left.\mathrm{CH}_{3}-\mathrm{Ph}\right)\right)$ and withdrawing substituents $\left[\mathbf{1 7 h}, \mathrm{R}^{1}=\mathrm{CH}_{2}(3-\right.$ $\left.\left.\mathrm{CF}_{3}-\mathrm{Ph}\right)\right]$ had equal activity $\left(\mathrm{MIC}_{\text {normoxia }}=0.06 \mu \mathrm{g} / \mathrm{mL}\right)$. Poor solubility of $\mathbf{1 7} \mathbf{j}$ in the compound stock solutions was suspected to have contributed to the unexpected weak activity of this disubstituted-fluorine derivative against M. tuberculosis and the other organisms. Replacement of the phenyl group (17b) with a pyridyl moiety (17k) was unfavorable and resulted in a loss of activity against $M$. tuberculosis (17k $\left.\mathrm{MIC}_{\text {normoxia }}>32 \mu \mathrm{g} / \mathrm{mL}\right)$. A methyl substituent at the benzylic position (17l) was well tolerated $\left(\mathrm{MIC}_{\text {normoxia }}=0.5 \mu \mathrm{g} / \mathrm{mL}\right)$, but extension of the aromatic linkage with an ethyl bridge in the phenethyl derivatives $(\mathbf{1 7} \mathbf{m}-\mathbf{n})$ resulted in a $16-32$-fold loss of activity against $M$. tuberculosis, with bacteriostatic activity of $\mathrm{MIC}_{\text {normoxia }}=4-8 \mu \mathrm{g} / \mathrm{mL}$ compared to respective benzyl derivatives $17 \mathrm{c}-\mathrm{d}$ with $\mathrm{MIC}_{\text {normoxia }}=0.125-0.5 \mu \mathrm{g} /$ $\mathrm{mL}$. None of the derivatives with polar groups at $\mathrm{R}^{1}(\mathbf{1 7 0}-\mathrm{s})$ had activity against $M$. tuberculosis $\left(\mathrm{MIC}_{\text {normoxia }}>32 \mu \mathrm{g} / \mathrm{mL}\right.$ ). Lastly, compound $\mathbf{1 7 t}$ with an aliphatic cyclohexyl group at $\mathrm{R}^{1}$ was also inactive $\left(\mathrm{MIC}_{\text {normoxia }}>32 \mu \mathrm{g} / \mathrm{mL}\right)$, indicating a preference for an aromatic group rather than a nonspecific lipophilic group.

In general, compounds with activity against M. tuberculosis grown in normoxic conditions were also active against nonreplicating $M$. tuberculosis under hypoxic conditions, although generally 2-16-fold less active. By comparison, isoniazid, a compound that inhibits cell wall synthesis in aerobically respiring $M$. tuberculosis $(\mathrm{MIC}=0.04 \mu \mathrm{g} / \mathrm{mL}) \mathrm{did}$ not inhibit growth in the hypoxic conditions (MIC $>5 \mu \mathrm{g}$ / $\mathrm{mL})$. Metronidazole 1 was inactive ( $\mathrm{MIC}>32 \mu \mathrm{g} / \mathrm{mL})$ in this hypoxic-recovery assay, indicating that the medium was not sufficiently anaerobic to show activity of 1 against $M$. tuberculosis.

The SARs observed for G. lamblia were similar to $M$. tuberculosis, and several compounds $(\mathbf{1 7} \mathbf{c}-\mathbf{d}, \mathbf{1 7 f}$, and $\mathbf{1 7 l}-\mathbf{n})$ were found to have improved activity (up to 4-fold) relative to metronidazole $1\left(\mathrm{IC}_{50}=1.6\right.$ to $3.5 \mu \mathrm{M}$ cf. $\left.1 \mathrm{IC}_{50}=7.2 \mu \mathrm{M}\right)$. Interestingly, an expanded range of the derivatives with lipophilic $\mathrm{R}^{1}$ groups had potent activity against G. lamblia. For example, $17 \mathbf{m}\left(\mathrm{R}^{1}=\mathrm{CH}_{2} \mathrm{CH}_{2}\left(4-\mathrm{OCF}_{3}-\mathrm{Ph}\right)\right)$ and $\mathbf{1 7 n}\left(\mathrm{R}^{1}\right.$ $\left.=\mathrm{CH}_{2} \mathrm{CH}_{2}(4-\mathrm{Me}-\mathrm{Ph})\right)$ had similar activity to the benzylsubstituted analogues $17 \mathrm{c}-\mathbf{d}$ against $\mathrm{G}$. lamblia $\left(\mathrm{IC}_{50}=1.6-\right.$ 3.2 $\mu \mathrm{M}$ vs 3.4-3.5 $\mu \mathrm{M}$, respectively). In addition, the cyclohexyl derivative $\mathbf{1 7 t}$ was potent against $G$. lamblia at equivalent levels to the metronidazole 1 control (17t G. lamblia $\mathrm{IC}_{50}=5.2 \mu \mathrm{M}$ ).

There were also similar trends in the SAR observed against $T$. $b$. brucei, although with a number of differences compared to M. tuberculosis and G. lamblia. For example, the activity of the benzyl series $\mathbf{1 7} \mathbf{b}-\mathbf{i}$ against $T$. $b$. brucei was sensitive to the particular nature of the benzyl substitution. For example, 17c $\left[\mathrm{R}^{1}=\mathrm{CH}_{2}\left(4-\mathrm{OCF}_{3}-\mathrm{Ph}\right)\right]$ and $17 \mathrm{e}\left[\mathrm{R}^{1}=\mathrm{CH}_{2}(4-\mathrm{F}-\mathrm{Ph})\right]$ were active against T. b. brucei ( $\mathrm{IC}_{50}=1.4$ and $2.9 \mu \mathrm{M}$, respectively), but compounds $17 \mathbf{b}\left(\mathrm{R}^{1}=\mathrm{CH}_{2} \mathrm{Ph}\right)$ and $\mathbf{1 7 f}\left[\mathrm{R}^{1}=\mathrm{CH}_{2}(3-\right.$ $\left.\left.\mathrm{OCF}_{3}-\mathrm{Ph}\right)\right]$ had reduced activity at the highest concentrations tested (40 and $16 \mu \mathrm{M}$, respectively). Another difference observed for T. $b$. brucei was an increased tolerance for polar substituents at $\mathrm{R}^{1}$. For example, compounds with polar ethyl acetate $(\mathbf{1 7 0})$ or morpholino groups $(\mathbf{1 7 q}-\mathbf{r})$ displayed moderate activity against $T . b$. brucei $\left(\mathrm{IC}_{50}=2.9-6.5 \mu \mathrm{M}\right)$, whereas against $M$. tuberculosis and G. lamblia, these examples were essentially devoid of activity. The unsubstituted nitroimidazopyrazinone compound $17 \mathrm{a}$ with $\mathrm{H}$ at $\mathrm{R}^{1}$ displayed some activity against T. b. brucei ( $97 \%$ inhibition at $40 \mu \mathrm{M})$ but was insufficiently active at $20 \mu \mathrm{M}$ to determine an $\mathrm{IC}_{50}$ value. The cyclohexyl derivative $\mathbf{1 7 t}$ also had good activity 
Table 3. SAR Exploring the Differences between the $R^{2}$ and $R^{3}$ Groups for the Imidazopyrazinone (Core $A$ ) vs the Imidazopyrazine (Core B)

\begin{tabular}{|c|c|c|c|c|c|c|c|c|c|c|}
\hline \multirow[b]{2}{*}{ no. } & \multirow[b]{2}{*}{ core } & \multicolumn{3}{|l|}{ compound } & \multirow[t]{2}{*}{$\begin{array}{c}\text { molecular } \\
\text { weight } \\
(\mathrm{g} / \mathrm{mol})\end{array}$} & \multicolumn{2}{|c|}{ antibacterial $\mathrm{MIC}(\mu \mathrm{g} / \mathrm{mL})$} & \multicolumn{3}{|c|}{ antiparasitic $\mathrm{IC}_{50}(\mu \mathrm{M})\left(\mathrm{pIC}_{50} \pm \mathrm{SE}\right)^{e}$} \\
\hline & & $\mathrm{R}^{1}$ & $\mathrm{R}^{2}$ & $\mathrm{R}^{3}$ & & $\begin{array}{c}M . \\
\text { tuberculosis }^{a} \\
\text { normoxia }\end{array}$ & $\begin{array}{c}\text { M. } \\
\text { tuberculosis }^{a} \\
\text { hypoxia }\end{array}$ & G. lamblia ${ }^{b}$ & E. histolytica ${ }^{c}$ & T. $b$ brucei $^{d}$ \\
\hline & & metronidazole $\mathbf{1}$ & & & 171.2 & $>32$ & $>32$ & $7.2(5.1 \pm 0.02)$ & $4.3(5.4 \pm 0.02)$ & $>40(<4.4)$ \\
\hline & & pretomanid 6 & & & 359.3 & $0.25-0.5$ & 1 & $3.0(5.5 \pm 0.02)$ & $9.3(5.0 \pm 0.03)$ & $19(4.7 \pm 2.4)$ \\
\hline 24a & A & $\mathrm{H}$ & $\mathrm{Ph}$ & $\mathrm{H}$ & 256.2 & $>32$ & $>32$ & $10(5.0 \pm 0.03)$ & $>25(<4.6)$ & $0.22(6.7 \pm 0.071)$ \\
\hline $24 b$ & A & $\mathrm{CH}_{2} \mathrm{CH}_{2} \mathrm{OAc}$ & $\mathrm{Ph}$ & $\mathrm{H}$ & 342.3 & $>32$ & $>32$ & $11(5.0 \pm 0.05)$ & $34(4.5 \pm 0.1)$ & $0.86(6.1 \pm 0.085)$ \\
\hline $24 \mathrm{c}$ & B & $\mathrm{CH}_{2} \mathrm{CH}_{2} \mathrm{OAc}$ & $\mathrm{Ph}$ & $\mathrm{H}$ & 342.3 & $>32$ & $>32$ & $1.9(5.7 \pm 0.05)$ & $>50(<4.3)$ & $1.5(5.8 \pm 0.085)$ \\
\hline 24d & A & $\mathrm{CH}_{2} \mathrm{CH}_{2} \mathrm{OH}$ & $\mathrm{Ph}$ & $\mathrm{H}$ & 300.3 & $>32$ & $>32$ & $38(4.4 \pm 0.03)$ & $>50(<4.3)$ & N.D. \\
\hline $24 \mathrm{e}$ & B & $\mathrm{CH}_{2} \mathrm{CH}_{2} \mathrm{OH}$ & $\mathrm{Ph}$ & $\mathrm{H}$ & 300.3 & $>32$ & $>32$ & $5.2(5.3 \pm 0.05)$ & $>50(<4.3)$ & $1.1(6.0 \pm 0.12)$ \\
\hline $25 a$ & A & $\mathrm{H}$ & $\mathrm{CH}_{3}$ & $\mathrm{H}$ & 194.2 & $>32$ & $>32$ & $\sim 50(\sim 4.3)$ & $>50(<4.3)$ & $3.6(5.4 \pm 0.20)$ \\
\hline $25 b$ & A & $\mathrm{CH}_{2} \mathrm{CH}_{2} \mathrm{OAc}$ & $\mathrm{CH}_{3}$ & $\mathrm{H}$ & 280.2 & $>32$ & $>32$ & $\sim 50(\sim 4.3)$ & $41 \% I @ 50 \mu \mathrm{M}$ & $0.65(6.2 \pm 0.021)$ \\
\hline $25 \mathrm{c}$ & B & $\mathrm{CH}_{2} \mathrm{CH}_{2} \mathrm{OAc}$ & $\mathrm{CH}_{3}$ & $\mathrm{H}$ & 280.2 & $>32$ & $>32$ & $21(4.7 \pm 0.06)$ & $42 \% I @ 50 \mu \mathrm{M}$ & $>40(<4.4)$ \\
\hline $25 d$ & A & $\mathrm{CH}_{2} \mathrm{CH}_{2} \mathrm{OH}$ & $\mathrm{CH}_{3}$ & $\mathrm{H}$ & 238.2 & $>32$ & $>32$ & $>50(<4.3)$ & $>50(<4.3)$ & $4.6(5.3 \pm 0.092)$ \\
\hline $25 \mathrm{e}$ & B & $\mathrm{CH}_{2} \mathrm{CH}_{2} \mathrm{OH}$ & $\mathrm{CH}_{3}$ & $\mathrm{H}$ & 238.2 & $>32$ & $>32$ & $80 \% I @ 50 \mu \mathrm{M}$ & $>50(<4.3)$ & $56 \% \mathrm{I} @ 40 \mu \mathrm{M}$ \\
\hline $25 \mathrm{f}$ & A & $\mathrm{CH}_{2}\left(4-\mathrm{OCF}_{3}-\mathrm{Ph}\right)$ & $\mathrm{CH}_{3}$ & $\mathrm{H}$ & 368.3 & $>32$ & $>32$ & $5.8(5.2 \pm 0.04)$ & $>50(<4.3)$ & $0.41(5.4 \pm 0.057)$ \\
\hline $25 \mathrm{~g}$ & B & $\mathrm{CH}_{2}\left(4-\mathrm{OCF}_{3}-\mathrm{Ph}\right)$ & $\mathrm{CH}_{3}$ & $\mathrm{H}$ & 368.3 & $>32$ & $>32$ & $7.4(5.1 \pm 0.03)$ & $9.5(5 \pm 0.07)$ & $>40(<4.4)$ \\
\hline $25 \mathrm{~h}$ & A & $\mathrm{CH}_{2}\left(4-\mathrm{CH}_{3}-\mathrm{Ph}\right)$ & $\mathrm{CH}_{3}$ & $\mathrm{H}$ & 298.3 & $>32$ & $>32$ & $4.4(5.4 \pm 0.03)$ & $10(5.0 \pm 1.0)$ & $0.56(6.3 \pm 0.028)$ \\
\hline $25 \mathrm{i}$ & B & $\mathrm{CH}_{2}\left(4-\mathrm{CH}_{3}-\mathrm{Ph}\right)$ & $\mathrm{CH}_{3}$ & $\mathrm{H}$ & 298.3 & N.D. & N.D. & $5.7(5.2 \pm 0.03)$ & $30(4.5 \pm 0.1)$ & N.D. \\
\hline $25 j$ & A & $\mathrm{CH}_{2}\left(3-\mathrm{OCF}_{3}-\mathrm{Ph}\right)$ & $\mathrm{CH}_{3}$ & $\mathrm{H}$ & 368.3 & $>32$ & $>32$ & $2.8(5.6 \pm 0.01)$ & $16(4.8 \pm 0.1)$ & $1.1(5.9 \pm 0.021)$ \\
\hline 251 & A & $\mathrm{CH}_{2}\left(2-\mathrm{OCF}_{3}-\mathrm{Ph}\right)$ & $\mathrm{CH}_{3}$ & $\mathrm{H}$ & 368.3 & $>32$ & $>32$ & $3.3(5.5 \pm 0.01)$ & $9.1(5 \pm 0.08)$ & $2.1(5.7 \pm 0.29)$ \\
\hline $25 \mathrm{~m}$ & B & $\mathrm{CH}_{2}\left(2-\mathrm{OCF}_{3}-\mathrm{Ph}\right)$ & $\mathrm{CH}_{3}$ & $\mathrm{H}$ & 368.3 & $>32$ & $>32$ & $5.7(5.2 \pm 0.02)$ & $>50(<4.3)$ & $1.2(5.9 \pm 0.13)$ \\
\hline $26 a$ & A & $\mathrm{H}$ & $\mathrm{CH}_{3}$ & $\mathrm{CH}_{3}$ & 208.2 & $>32$ & $>32$ & $\sim 50(\sim 4.3)$ & $>50(<4.3)$ & $2.6(5.6 \pm 0.17)$ \\
\hline $26 b$ & A & $\mathrm{CH}_{2}\left(4-\mathrm{OCF}_{3}-\mathrm{Ph}\right)$ & $\mathrm{CH}_{3}$ & $\mathrm{CH}_{3}$ & 382.3 & 1 & 4 & $4.2(5.4 \pm 0.04)$ & $10(5 \pm 0.1)$ & $\begin{array}{l}0.24 \\
(5.7 \pm 0.0071)\end{array}$ \\
\hline $26 c$ & B & $\mathrm{CH}_{2}\left(4-\mathrm{OCF}_{3}-\mathrm{Ph}\right)$ & $\mathrm{CH}_{3}$ & $\mathrm{CH}_{3}$ & 382.3 & $>32$ & $>32$ & $8.6(5.1 \pm 0.04)$ & $17(4.8 \pm 0.09)$ & $10(5.0 \pm 0.20)$ \\
\hline $26 \mathrm{~d}$ & A & $\mathrm{CH}_{2}\left(4-\mathrm{CH}_{3}-\mathrm{Ph}\right)$ & $\mathrm{CH}_{3}$ & $\mathrm{CH}_{3}$ & 312.3 & 2 & 4 & $5.2(5.3 \pm 0.02)$ & $33(4.5 \pm 0.04)$ & $\begin{array}{l}0.25 \\
(6.6 \pm 0.0071)\end{array}$ \\
\hline $26 \mathrm{e}$ & B & $\mathrm{CH}_{2}\left(4-\mathrm{CH}_{3}-\mathrm{Ph}\right)$ & $\mathrm{CH}_{3}$ & $\mathrm{CH}_{3}$ & 312.3 & $>32$ & $>32$ & $5.8(5.2 \pm 0.02)$ & $>50(<4.3)$ & $2.2(5.6 \pm 0.31)$ \\
\hline $26 f$ & A & $\mathrm{CH}_{2}\left(3-\mathrm{OCF}_{3}-\mathrm{Ph}\right)$ & $\mathrm{CH}_{3}$ & $\mathrm{CH}_{3}$ & 382.3 & 1 & $16-32$ & $1.7(5.8 \pm 0.01)$ & $15(4.8 \pm 0.03)$ & $\begin{array}{l}0.40 \\
(6.4 \pm 0.0071)\end{array}$ \\
\hline $26 \mathrm{~g}$ & B & $\mathrm{CH}_{2}\left(3-\mathrm{OCF}_{3}-\mathrm{Ph}\right)$ & $\mathrm{CH}_{3}$ & $\mathrm{CH}_{3}$ & 382.3 & $>32$ & $>32$ & $3.9(5.4 \pm 0.01)$ & $27(4.6 \pm 0.02)$ & $1.4(5.9 \pm 0.24)$ \\
\hline $26 \mathrm{~h}$ & A & $\mathrm{CH}_{2}\left(2-\mathrm{OCF}_{3}-\mathrm{Ph}\right)$ & $\mathrm{CH}_{3}$ & $\mathrm{CH}_{3}$ & 382.3 & $>32$ & $>32$ & $5.3(5.3 \pm 0.03)$ & $18(4.7 \pm 0.02)$ & $0.78(6.1 \pm 0.090)$ \\
\hline $26 \mathrm{i}$ & $\mathrm{B}$ & $\mathrm{CH}_{2}\left(2-\mathrm{OCF}_{3}-\mathrm{Ph}\right)$ & $\mathrm{CH}_{3}$ & $\mathrm{CH}_{3}$ & 382.3 & $>32$ & $>32$ & $>50(<4.3)$ & $>50(<4.3)$ & $1.9(5.7 \pm 0.27)$ \\
\hline
\end{tabular}

${ }^{a} \mathrm{H} 37 \mathrm{Rv}$, M. tuberculosis-normoxia primary screen at $32 \mu \mathrm{g} / \mathrm{mL} n=3$, M. tuberculosis-hypoxia primary screen at $32 \mu \mathrm{g} / \mathrm{mL} n=1-3$, MIC-normoxia/ hypoxia of active compounds $n=3-6$. Isoniazid control M. tuberculosis-normoxia MIC $=0.04 \mu \mathrm{g} / \mathrm{mL}, M$. tuberculosis-hypoxia MIC $>5 \mu \mathrm{g} / \mathrm{mL}$. ${ }^{b}$ WB. ${ }^{c} \mathrm{HM1}$ :IMSS. ${ }^{d}$ Pentamidine control $\mathrm{IC}_{50}=0.002 \mu \mathrm{M}\left(\mathrm{pIC}_{50}=8.7\right)$, diminazine aceturate $\mathrm{IC}_{50}=0.062 \mu \mathrm{M}\left(\mathrm{pIC} C_{50}=7.2\right)$, puromycin $\mathrm{IC}_{50}=$ $0.05 \mu \mathrm{M}\left(\mathrm{pIC}_{50}=7.3\right), n=2 .{ }^{e}$ The percentage inhibition (\% I) at the highest concentration tested is reported for compounds that were not sufficiently active to determine an $\mathrm{IC}_{50}$.

against T. b. brucei $\left(\mathrm{IC}_{50}=1.4 \mu \mathrm{M}\right)$, similarly to G. lamblia. These examples demonstrate that it is possible to identify compounds with selective antiparasitic activity, although all compounds with $M$. tuberculosis activity tended to display some activity toward parasites. The selectivity observed for the particular organisms may be due to differences in the compound activation or uptake of the compounds and is an area of ongoing investigation.

Comparison of Bicyclic Antimicrobial Activity to Monocyclic 4- and 4(5)-Nitroimidazole Carboxamide Analogues. Given the activity of the bicyclic derivatives against $M$. tuberculosis, we screened a number of previously reported $^{28}$ 4-nitroimidazole carboxamides $\mathbf{2 8 b}-\mathbf{k}$ and $4(5)$ nitroimidazole carboxamides 16a, 16c, 16e, and 16f, along with intermediates $16 \mathrm{~b}$ and $16 \mathrm{~d}$ prepared for this study, against M. tuberculosis under normoxic and hypoxic growth conditions. This would allow us to compare the SAR between the monocyclic and bicyclic series. Note that the 2-nitro group of the imidazopyrazinones occupies the equivalent position of the nitro group in the 4-nitroimidazole series (Figure 3). Interestingly, none of the 4- or 4(5)-monocyclic nitroimidazoles tested were active against $M$. tuberculosis grown aerobically at $32 \mu \mathrm{g} / \mathrm{mL}$ (Supporting Information, Table S6). Under hypoxic growth conditions, weak activity was observed for $28 \mathrm{j}$ and $16 \mathrm{c}(60-75 \%$ inhibition at $32 \mu \mathrm{g} / \mathrm{mL})$, but this also correlated with increased cytotoxicity against the mammalian kidney cell line for these compounds (Supporting Information, Table S6). Therefore, the rigid, bicyclic nature of $\mathbf{1 7 b}-\mathbf{f}$ appears necessary for antitubercular activity, especially against actively dividing M. tuberculosis cells, but is not essential for activity against other parasites. A comparison of the activity of the 4- and 4(5)-nitroimidazole carboxamide series with that of the bicyclic derivatives is summarized in Figure 3.

Evaluation of Des-nitro Derivatives for Biological Activity. Two des-nitro derivatives $20 \mathrm{~b}-\mathrm{c}$ were prepared as negative control compounds to confirm that the proposed mode of action relies on reduction of the nitro group. The desnitro imidazopyrazinone derivatives $20 \mathbf{b}-\mathbf{c}$ were tested for 
Table 4. In Vitro Physicochemical Properties for Representative Compounds ${ }^{a}$

\begin{tabular}{|c|c|c|c|c|c|c|c|c|c|}
\hline \multirow[b]{2}{*}{ compound } & \multirow[b]{2}{*}{ core } & \multirow[b]{2}{*}{$\mathrm{R}^{1}$} & \multirow[b]{2}{*}{$\mathrm{R}^{2}$} & \multirow[b]{2}{*}{$\mathrm{R}^{3}$} & \multicolumn{2}{|c|}{$\begin{array}{c}\text { microsomal stability (\% remaining } \\
\text { at } 2 \mathrm{~h} \text { ) }\end{array}$} & \multicolumn{2}{|c|}{$\begin{array}{l}\text { plasma stability (\% remaining at } \\
2 \mathrm{~h} \text { ) }\end{array}$} & \multirow[b]{2}{*}{ PPB (\%) } \\
\hline & & & & & human & mouse (CD-1) & human & mouse (CD-1) & \\
\hline & & pretomanid 6 & & & $97 \pm 5.0$ & $92 \pm 2.7$ & $96 \pm 6.9$ & $96 \pm 1.9$ & $97 \pm 1.1$ \\
\hline $17 \mathrm{c}$ & A & $\mathrm{CH}_{2}\left(4-\mathrm{OCF}_{3}-\mathrm{Ph}\right)$ & $\mathrm{H}$ & $\mathrm{H}$ & $>99$ & $>99$ & $>99$ & $>99$ & $98 \pm 0.4$ \\
\hline $17 d$ & A & $\mathrm{CH}_{2}\left(4-\mathrm{CH}_{3}-\mathrm{Ph}\right)$ & $\mathrm{H}$ & $\mathrm{H}$ & $97 \pm 1.1$ & $96 \pm 6.0$ & $>99$ & $>99$ & N.D \\
\hline $17 \mathrm{e}$ & A & $\mathrm{CH}_{2}(4-\mathrm{F}-\mathrm{Ph})$ & $\mathrm{H}$ & $\mathrm{H}$ & 99 & $>99$ & $98 \pm 1.4$ & $>99$ & $82 \pm 0.3$ \\
\hline $17 \mathrm{f}$ & A & $\mathrm{CH}_{2}\left(3-\mathrm{OCF}_{3}-\mathrm{Ph}\right)$ & $\mathrm{H}$ & $\mathrm{H}$ & $>99$ & $>99$ & $>99$ & $97 \pm 2.2$ & $99 \pm 0.2$ \\
\hline $17 \mathrm{i}$ & $\mathrm{A}$ & $\mathrm{CH}_{2}\left(2-\mathrm{OCF}_{3}-\mathrm{Ph}\right)$ & $\mathrm{H}$ & $\mathrm{H}$ & $>99$ & $>99$ & N.D & N.D & N.D \\
\hline $18 \mathrm{i}$ & $\mathrm{B}$ & $\mathrm{CH}_{2}\left(2-\mathrm{OCF}_{3}-\mathrm{Ph}\right)$ & $\mathrm{H}$ & $\mathrm{H}$ & $51 \pm 18$ & $<0.5$ & N.D & N.D & N.D \\
\hline $25 f$ & A & $\mathrm{CH}_{2}\left(4-\mathrm{OCF}_{3}-\mathrm{Ph}\right)$ & $\mathrm{CH}_{3}$ & $\mathrm{H}$ & $>99$ & $>99$ & $92 \pm 4.1$ & $99 \pm 4.8$ & $98 \pm 0.4$ \\
\hline $25 \mathrm{~g}$ & B & $\mathrm{CH}_{2}\left(4-\mathrm{OCF}_{3}-\mathrm{Ph}\right)$ & $\mathrm{CH}_{3}$ & $\mathrm{H}$ & $69 \pm 4.3$ & $7.9 \pm 4.0$ & $94 \pm 4.7$ & $>99$ & $>99$ \\
\hline $26 b$ & A & $\mathrm{CH}_{2}\left(4-\mathrm{OCF}_{3}-\mathrm{Ph}\right)$ & $\mathrm{CH}_{3}$ & $\mathrm{CH}_{3}$ & $92 \pm 1.1$ & $3.6 \pm 0.1$ & $97 \pm 1.4$ & $>99$ & $99 \pm 0.1$ \\
\hline $26 c$ & $\mathrm{~B}$ & $\mathrm{CH}_{2}\left(4-\mathrm{OCF}_{3}-\mathrm{Ph}\right)$ & $\mathrm{CH}_{3}$ & $\mathrm{CH}_{3}$ & $44 \pm 0.98$ & $<0.5$ & $>99$ & $>99$ & N.D \\
\hline
\end{tabular}

${ }^{a}$ Values are presented as mean of three replicates \pm SD. N.D represents not determined. Microsome stability verapamil control $=2 \%(\mathrm{MLM}), 9 \%$ $(\mathrm{HLM})$ remaining at $30 \mathrm{~min}$; plasma stability eucatropine control $=28 \%$ (mouse), $21 \%$ (human) remaining at 2 h; and PPB sulfamethoxazole control $=68 \%$ bound.

activity and indeed were found to be inactive against $M$. tuberculosis, G. lamblia, T. b. brucei, and E. histolytica (complete profiling results are detailed in the Supporting Information, Table S7). This result is consistent with the inactivity of a desnitro pretomanid analogue 9 against $M$. tuberculosis under both aerobic and anaerobic growth (MIC $>160$ and $>500 \mu \mathrm{M}$, respectively $)^{41}$ and supports a critical role for the nitro group in the mechanism of action of nitroimidazopyrazinones.

SAR of Bicyclic Nitroimidazoles with Variation at $\mathbf{R}^{2}=$ $\mathrm{Ph}$ or $\mathrm{CH}_{3}, \mathrm{R}^{3}=\mathrm{H}$ or $\mathrm{CH}_{3}$. Compounds $24 \mathrm{a}-\mathrm{e}, 25 \mathrm{a}-\mathrm{m}$, and 26a-i with $\mathrm{R}^{2}=\mathrm{Ph}$ or $\mathrm{CH}_{3}$ and $\mathrm{R}^{3}=\mathrm{H}$ or $\mathrm{CH}_{3}$ were evaluated for antiparasitic and antimicrobial in the same manner as described for $\mathbf{1 7} \mathbf{a}-\mathbf{t}, \mathbf{1 8 i}$, and $\mathbf{1 8 m}$ (Table 3 ). Both the $\mathrm{R}^{2}$ and $\mathrm{R}^{3}$ sites were found to influence activity against different pathogens to varying degrees. Interestingly, the modifications of $\mathrm{R}^{2}$ and $\mathrm{R}^{3}$ on the nitroimidazopyrazinone series were found to be particularly beneficial for activity against $T$. $b$. brucei. A number of nitroimidazopyrazinones were active against $T . b$. brucei between 0.2 and $0.9 \mu \mathrm{M}(\mathbf{2 4 a}-\mathbf{b}, \mathbf{2 5 b}, \mathbf{2 5 f}, \mathbf{2 5 h}, \mathbf{2 6 \mathbf { b }}$, 26d, 26f, and 26h). While some of the pyrazine matched pairs generally lost activity, several compounds (24c, 25m, 26e, 26g, and 26i) maintained activity in the $1.2-2.2 \mu \mathrm{M}$ range. Furthermore, when $\mathrm{R}^{1}=\mathrm{CH}_{2} \mathrm{CH}_{2} \mathrm{OAc}$, compound 24b $\left(\mathrm{R}^{2}\right.$ $=\mathrm{Ph})$ and $25 \mathbf{b}\left(\mathrm{R}^{2}=\mathrm{CH}_{3}\right)$ showed 7.6-10-fold improvement compared to $170\left(R^{2}=H\right)$. This benefit was also clear for the derivatives with benzyl substitutions at $\mathrm{R}^{1}$. For example, compound 17f $\left(\mathrm{R}^{1}=\mathrm{CH}_{2}\left(3-\mathrm{OCF}_{3}-\mathrm{Ph}\right), \mathrm{R}^{2}=\mathrm{H}, \mathrm{R}_{3}=\mathrm{H}\right)$ showed incomplete inhibition at $16 \mu \mathrm{M}$, while the matched pairs 25j $\left(\mathrm{R}^{2}=\mathrm{CH}_{3}, \mathrm{R}^{3}=\mathrm{H}\right)$ and $26 \mathbf{f}\left(\mathrm{R}^{2}=\mathrm{CH}_{3}, \mathrm{R}^{3}=\mathrm{CH}_{3}\right)$ inhibited T. b. brucei at 1.1 and $0.40 \mu \mathrm{M}$, respectively. This last example also demonstrates a slight preference for methyl group substitutions at both $\mathrm{R}^{2}$ and $\mathrm{R}^{3}$ on the pyrazinone ring, as this resulted in activity that was consistently about twofold improved.

The methyl and phenyl groups explored at $\mathrm{R}^{2}$ and $\mathrm{R}^{3}$ did not result in any overall improvement or loss of activity against $G$. lamblia, as the activity was generally in the same range. As observed for nitroimidazopyrazine $\mathbf{1 8 m}$, the expanded series of nitroimidazopyrazine derivatives also had activity against $G$. lamblia. When $\mathrm{R}^{2}=\mathrm{Ph}, \mathrm{R}^{3}=\mathrm{H}$, the pyrazine derivatives $24 \mathrm{c}$ and $24 \mathrm{e}$ performed better than the pyrazinone analogues $24 \mathrm{~b}$ and $\mathbf{2 4 d}$ against $G$. lamblia. However, similar activity was observed when $\mathrm{R}^{2}=\mathrm{CH}_{3}, \mathrm{R}^{3}=\mathrm{H}$ (e.g., matched pair $\mathbf{2 5 h}$ and 25i) and $\mathrm{R}^{2}=\mathrm{CH}_{3}, \mathrm{R}^{3}=\mathrm{CH}_{3}$ (e.g., matched pair 26d and 26e), although the pyrazine was slightly worse by twofold for a few derivatives.

Activity against E. histolytica was also improved for the nitroimidazopyrazine series when $\mathrm{R}^{2}=\mathrm{CH}_{3}$ and $\mathrm{R}^{3}=\mathrm{CH}_{3}$. Both nitroimidazopyrazinones (e.g., 26b and 26f) and nitroimidazopyrazines (e.g., 26c and 26g) were active, with a slight preference for the nitroimidazopyrazinone core. Despite this improvement, none of the derivatives had activity comparable to metronidazole $\mathbf{1}$, with the active derivatives having only moderate to weak activity $(10-34 \mu \mathrm{M})$. This suggests distinct requirements for activity in E. histolytica compared to T. b. brucei and G. lamblia. Nonetheless, it is possible that further modification of the scaffold may lead to identification of an optimal "sweet spot" for activity against $E$. histolytica.

Modifications explored at $\mathrm{R}^{2}$ and $\mathrm{R}^{3}$ were mostly detrimental for activity against $M$. tuberculosis. Activity against $M$. tuberculosis activity was abolished when $\mathrm{R}^{2}=\mathrm{CH}_{3}$ or $\mathrm{Ph}$ and $\mathrm{R}^{3}=\mathrm{H}$. Consistent with the previous SAR study, all of the nitroimidazopyrazines were found to be inactive (MIC > 32 $\mu \mathrm{g} / \mathrm{mL})$. Nonetheless, activity was retained for three nitroimidazopyrazinone examples (26b, 26d, and 26f) when $R^{2}=$ $\mathrm{R}^{3}=\mathrm{CH}_{3}$ and $\mathrm{R}^{1}$ was a benzyl group. Compounds $26 \mathrm{~b}, 26 \mathrm{~d}$, and $26 \mathrm{f}$ also displayed activity against $M$. tuberculosis under hypoxic growth conditions and against G. lamblia, E. histolytica, and $T . b$. brucei. These results indicate that it is possible to identify compounds with broad spectrum activity against both M. tuberculosis and parasites.

Continuing the trend previously observed for compounds $17 \mathrm{a}-\mathrm{t}, 18 \mathrm{i}$, and $18 \mathrm{~m}$, none of the additional nitroimidazopyrazin-ones/-es synthesized had appreciable activity against ESKAPE bacteria or fungal pathogens ( $\mathrm{MIC} \geq 32 \mu \mathrm{g} / \mathrm{mL}$ ) (Supporting Information, Table S8). Both the nitroimidazopyrazinone and nitroimidazopyrazine series were also not cytotoxic against mammalian liver and kidney cell lines $\left(\mathrm{CC}_{50}\right.$ $>100 \mu \mathrm{M}, 24 \mathrm{~d}>75 \mu \mathrm{M}$ due to compound limitations), except for $26 \mathrm{f}$ that displayed moderate cytotoxicity in both cell lines $\left(\mathrm{CC}_{50}=26-80 \mu \mathrm{M}\right)$ (Supporting Information, Table S8).

To summarize, the SAR of the $\mathrm{R}^{2}, \mathrm{R}^{3}$ sites was determined for both the nitroimidazopyrazinone and nitroimidazopyrazine series. Several compounds with potent activity against $M$. tuberculosis, G. lamblia, and T. b. brucei were identified. Further 
Table 5. Caco-2 Permeability of Selected Analogues ${ }^{a}$

\begin{tabular}{|c|c|c|c|c|c|c|c|c|c|}
\hline \multirow[b]{2}{*}{ compound } & \multirow[b]{2}{*}{ core } & \multirow[b]{2}{*}{$\mathrm{R}^{1}$} & \multirow[b]{2}{*}{$\mathrm{R}^{2}$} & \multirow[b]{2}{*}{$\mathrm{R}^{3}$} & \multicolumn{2}{|c|}{$P_{\mathrm{app}}\left(10^{-6} \mathrm{~cm} / \mathrm{s}\right)$} & \multicolumn{2}{|c|}{ mean recovery $(\%)$} & \multirow[b]{2}{*}{ efflux ratio } \\
\hline & & & & & $A$ to $B$ & $\mathrm{~B}$ to $\mathrm{A}$ & $A$ to $B$ & $A$ to $B$ & \\
\hline & & pretomanid $6^{*}$ & & & 29 & 22 & 81 & 101 & 0.74 \\
\hline & & fenoterol & & & 0.27 & N.D & 92 & N.D & N.D \\
\hline & & propranolol & & & 21 & N.D & 70 & N.D & N.D \\
\hline & & digoxin & & & $<0.020$ & 8.4 & $<72$ & 88 & $>360$ \\
\hline $17 \mathrm{c}$ & A & $\mathrm{CH}_{2}\left(4-\mathrm{OCF}_{3}-\mathrm{Ph}\right)$ & $\mathrm{H}$ & $\mathrm{H}$ & 25 & 22 & 83 & 97 & 0.88 \\
\hline $17 f$ & A & $\mathrm{CH}_{2}\left(3-\mathrm{OCF}_{3}-\mathrm{Ph}\right)$ & $\mathrm{H}$ & $\mathrm{H}$ & 24 & 24 & 88 & 99 & 1.0 \\
\hline $26 b$ & A & $\mathrm{CH}_{2}\left(4-\mathrm{OCF}_{3}-\mathrm{Ph}\right)$ & $\mathrm{CH}_{3}$ & $\mathrm{CH}_{3}$ & 21 & 20 & 83 & 97 & 0.95 \\
\hline
\end{tabular}

${ }^{a}$ N.D represents not determined. * Comparable results with the literature. ${ }^{22}$

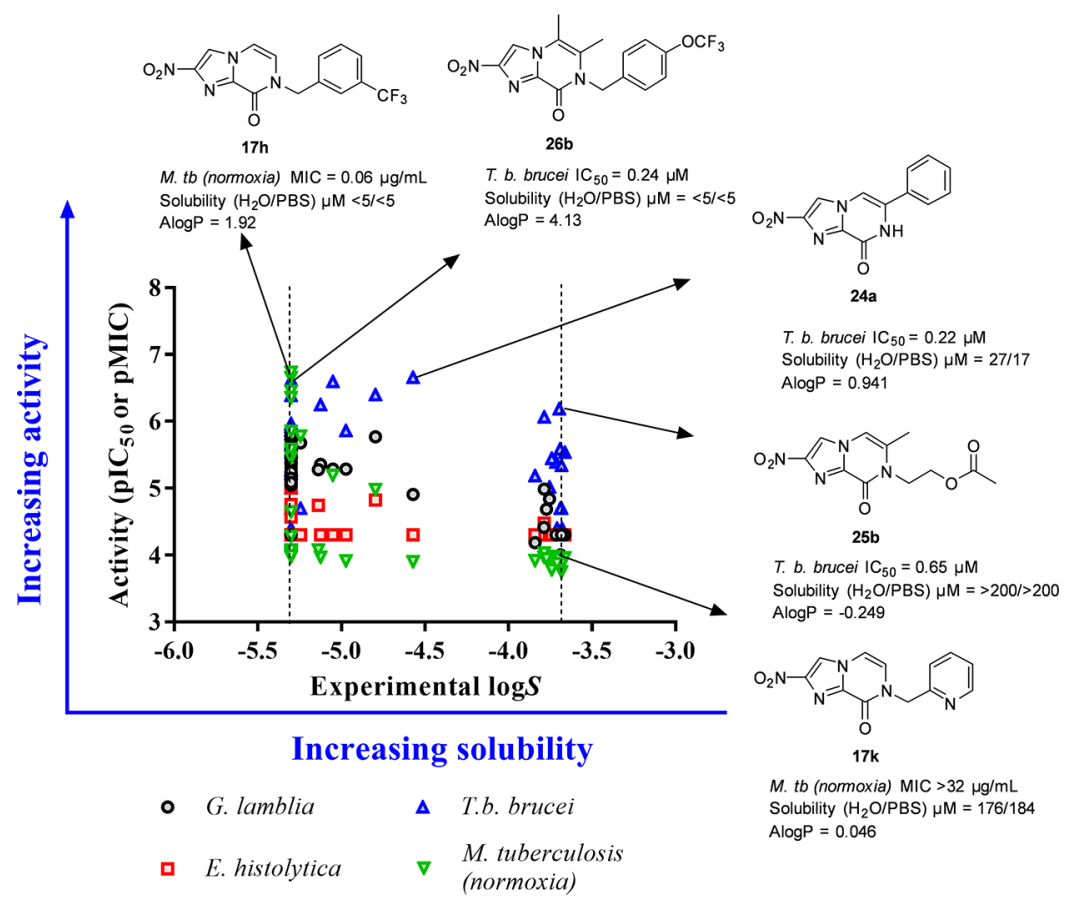

Figure 4. Comparison of activity vs aqueous solubility data. Several compounds, for example, 25b active against T. b. brucei (in blue) had good solubility ( $>100 \mu \mathrm{M}$ or $\log S>-4)$. Most of the potent compounds, for example, $\mathbf{1 7 h}$, against the other organisms displayed poor solubility (log $S$ $\leq-5$ ). Dashed lines represent the minimum and maximum range of solubility determined experimentally.

work confirming the target/mode of action in M. tuberculosis, G. lamblia, and T. b. brucei could aid in explaining the differences in activity. Additional studies to measure the reduction potential may provide insight into the differences in the activity between the nitroimidazopyrazinones and nitroimidazopyrazines.

Microsomal Stability, Plasma Stability, and PPB. A set of 10 compounds was selected for initial assessment of druglike properties (microsomal stability, plasma stability, and $\mathrm{PPB}$ ) based on their potency and structural diversity (Table 4). It was also envisioned that these studies would provide clarity as to whether there was a clear benefit to either the nitroimidazopyrazinone or nitroimidazopyrazine series from the perspective of ADMET properties. Nitroimidazopyrazinones were stable in human liver microsomes (HLM) after $2 \mathrm{~h}$ of incubation, regardless of the structural differences in $R^{1}, R^{2}$, and $\mathrm{R}^{3}$. However, 18i, 25g, and $26 \mathrm{c}$ from the nitroimidazopyrazine series only showed moderate stability in HLM, independent of differences at $R^{1}, R^{2}$, and $R^{3}$, with 44$69 \%$ of the compound remaining after $2 \mathrm{~h}$ (Table 4 ).

To further understand how the metabolic stability could impact in vivo efficacy studies, metabolic stability was evaluated in CD-1 mouse liver microsomes (MLM) because the CD-1 mouse strain is intended to be used for future in vivo efficacy studies. As for HLM, the majority of the nitroimidazopyrazinones $\mathbf{1 7} \mathbf{c}-\mathbf{f}, \mathbf{1 7} \mathbf{i}$, and $\mathbf{2 5 f}$ displayed excellent stabilities toward MLM. However, one of the imidazopyrazinone analogues, $\mathbf{2 6} \mathbf{b}\left(\mathrm{R}^{2}=\mathrm{R}^{3}=\mathrm{CH}_{3}\right)$ showed significant degradation after $2 \mathrm{~h}$, with only $3.6 \%$ of intact compound remaining (compared to $92 \%$ in HLM) (Table 4). Comparison of $\mathbf{2 5 f}$ with $\mathbf{2 6 b}$, which differ by the presence of a hydrogen or methyl group at $\mathrm{R}^{3}$, respectively, indicated that the methyl group at $\mathrm{R}^{3}$ was responsible for the high intrinsic clearance of 26b in MLM. Nitroimidazopyrazines, 18i, 25g, and 26c were also not stable in MLM ( $<0.5-8 \%$ remaining), suggesting a metabolic liability of this series.

Compound stability in both human and mouse (CD-1)

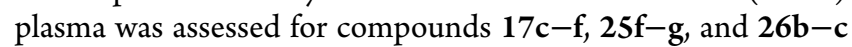
(Table 4). All of the examples had $>90 \%$ of compound remaining after $2 \mathrm{~h}$ at $37{ }^{\circ} \mathrm{C}$, similar to pretomanid 6 . Therefore, both the nitroimidazopyrazinone and nitroimidazopyrazine series were stable in human and mouse plasma, despite the instability of nitroimidazopyrazines observed in liver microsomes. 
PPB affects compound bioavailability and tissue distribution in vivo. Therefore, to understand PPB for the nitroimidazopyrazinone and nitroimidazopyrazine series, selected potent compounds $(17 \mathrm{c}, 17 \mathrm{e}-\mathrm{f}, \mathbf{2 5 f}-\mathrm{g}$, and $26 \mathrm{~b})$ were evaluated for PPB using the ultrafiltration method (Table 4). Most of the tested compounds, except 17 e ( $82 \%$ bound), had high PPB at $>95 \%$, which might limit the concentration of free compounds at the site of infection. However, as many approved and clinical drugs, including 6 , tend to have high $\mathrm{PPB}$, this parameter is not recommended to be optimized in early drug design. ${ }^{42}$

Caco-2 Intestinal Epithelium Permeability. An in vitro Caco-2 monolayer bidirectional assay was used to evaluate intestinal epithelium permeability and to predict the oral absorption of the nitroimidazopyrazinone series. ${ }^{43}$ Three derivatives (17c, 17f, and 26b) were selected based on potency against $M$. tuberculosis, G. lamblia, and T. b. brucei and to permit direct comparison of $\mathrm{R}_{2}=\mathrm{R}_{3}=\mathrm{H}(17 \mathrm{c})$ versus $\mathrm{R}_{2}=$ $\mathrm{R}_{3}=\mathrm{CH}_{3}$ (26b). Pleasingly, compounds 17c, 17f, and 26b were highly permeable (Table 5 ). The apparent permeability coefficient $\left(P_{\text {app }}\right)$ apical to basal (A to B) had values of $>20 \times$ $10^{-6} \mathrm{~cm} / \mathrm{s}$, similar to pretomanid 6 and propranolol, with the latter used as a positive control for high permeability. No metabolism of the compounds by Caco- 2 cells was observed. This was evident from the high recovery of tested nitroimidazopyrazinones obtained in both directions, similar to the control propranolol (A to B measured). Nitroimidazopyrazinones $17 \mathrm{c}, 17 \mathrm{f}$, and $26 \mathrm{~b}$ and 6 also showed a low efflux ratio of $<2$ (cf. digoxin efflux ratio $>360$ as it is a substrate for P-gp). Therefore, the tested bicyclic nitroimidazoles do not appear to be substrates of efflux transporters. These results suggest that 17c, 17f, and 26b have desirable therapeutic properties and may display good oral absorption properties in vivo.

Kinetic Solubility. Compound solubility impacts in vivo absorption, efficacy, and dosing and is thus an important parameter to optimize drug development. For example, the recently approved TB drug, delamanid has limited solubility which requires twice daily dosing, ${ }^{44}$ and new bicyclic analogues with improved solubility would be of great interest. According to the generic criteria for hits and leads in infectious diseases identified by Japanese Global Health Innovative Technology (GHIT) Fund and its key partners, a lead should have acceptable physicochemical properties, with solubility at least $>10 \mu \mathrm{M}$ in phosphate-buffered saline (PBS) $\mathrm{pH} 7.4 .^{45}$

The kinetic solubility of 48 compounds from the nitroimidazopyrazin-one/-e libraries in water and PBS buffer $(\mathrm{pH}$ 7.4) was determined using LC-UV (Figure 4, for full data, see Supporting Information, Table S9). The solubility of the derivatives varied over a wide range reflective of the different properties that the $\mathrm{R}^{1}$ side chain can impart. As anticipated, polar groups at $\mathrm{R}^{1}$ such as morpholine (17r: $\mathrm{CH}_{2} \mathrm{CO}$ morpholine and $17 \mathrm{q}: \mathrm{CH}_{2} \mathrm{CH}_{2}$-morpholine), amide (17s: $\mathrm{CH}_{2} \mathrm{CONH}_{2}$ ), and alcohol groups (17p: $\left.\mathrm{CH}_{2} \mathrm{CH}_{2} \mathrm{OH}\right)$ had $>30$-fold $(\Delta \log S \approx 1.6$ units) better solubility than benzyl derivatives $(\mathbf{1 7} \mathbf{b}-\mathbf{j})$. The nitroimidazopyrazinones had equivalent or improved solubility relative to the nitroimidazopyrazine series, and this is also reflected in their lower $\log P$ values. Encouragingly, when the solubility versus activity was compared, a number of compounds with antitrypanosomal activity $\left(T\right.$. b. brucei $\left.\mathrm{IC}_{50} \leq 10 \mu \mathrm{M}\right)$ had good solubility at $>100 \mu \mathrm{M}$ (equivalent to $\log S>-4$ ), including two potential hits $24 \mathbf{b}$ and $25 \mathbf{b}$ with $\mathrm{IC}_{50}<1 \mu \mathrm{M}$. The most potent compound 24a achieved moderate aqueous solubility $(27 \mu \mathrm{M}$ in water; $17 \mu \mathrm{M}$ in PBS), whereas $26 \mathrm{~b}$ and $26 \mathrm{~d}$ with comparable activity were poorly soluble $(<10 \mu \mathrm{M}$, or $\log S<$ -5 in water and PBS) (Figure 4$)$. These results demonstrate the potential to achieve desirable solubility and activity profile by modifying the $\mathrm{R}^{1}$ group of the bicyclic nitroimidazoles.

However, compounds with potent activity against $M$. tuberculosis, G. lamblia, and E. histolytica generally had poor solubility. Most of the potent compounds against $M$. tuberculosis showed poor solubility with $<10 \mu \mathrm{M}$ in both water and PBS, which might require complicated formulations for in vivo efficacy. This indicates the importance of lipophilicity at the $\mathrm{R}^{1}$ side chain, which is potentially required for penetration of these molecules through the mycobacterial cell walls. Although changing $\mathrm{R}^{1}$ to $\mathrm{CH}_{2}$-pyridinyl decreased activity against $M$. tuberculosis, this derivative (17k) had significantly improved water solubility $(176 \mu \mathrm{M}$ in water; 184 $\mu \mathrm{M}$ in PBS) and decreased lipophilicity ( $\Delta \log P-0.94$ units). Exploring other heterocyclic analogues may provide the desired balance of potency and solubility, which has been a successful strategy in the literature to identify analogues of pretomanid 6 with improved solubility. ${ }^{46,47}$

\section{CONCLUSIONS}

In this study, pretomanid $\mathbf{6}$ was shown to have potent activity against enteric pathogens including G. lamblia, E. histolytica, and $C$. difficile. These results expand the current understanding of the spectrum of action of $\mathbf{6}$ from Mycobacterium and Leishmania to include anaerobic protozoan parasites and an anaerobic Gram-positive bacterium. The in vitro activity of 6 against G. lamblia and E. histolytica at equivalent levels to metronidazole 1 suggests that this class of compounds and other subclasses of bicyclic nitroimidazoles could be a beneficial avenue to explore for the development of new nitroimidazole-based therapeutics against these pathogens.

The activity of 6 against enteric pathogens inspired the synthesis and biological evaluation of two new bicyclic scaffolds; nitroimidazopyrazin-one/-es derived from the monocyclic 4(5)-nitroimidazole carboxamide framework previously reported. A modular synthetic approach enabled the exploration of bicyclic imidazopyrazinone derivatives with different substitutions at $\mathrm{R}^{1}, \mathrm{R}^{2}$, and $\mathrm{R}^{3}$, along with the isomeric $\mathrm{O}$-alkylated nitroimidazopyrazine core scaffold. Through these studies, compounds with potent activity against M. tuberculosis, G. lamblia, and T. b. brucei were identified. Several compounds also displayed moderate activity against $E$. histolytica. To our knowledge, this is the first example of a nitroimidazopyrazinone heterocyclic core with potent antitubercular activity against $M$. tuberculosis under both normoxic and hypoxic growth conditions as well as promising antiparasitic activity against $G$. lamblia and $T$. b. brucei. In addition, the bicyclic core was essential for antitubercular activity.

This study highlights the potential to prepare new subclasses of bicyclic nitroimidazoles with varied ring systems to gain different selectivity profiles toward $M$. tuberculosis and a range of parasitic organisms. All of the compounds with $M$. tuberculosis activity also displayed activity toward at least some of the parasites tested. However, we showed that the activity profile of the series could be tuned toward parasites away from $M$. tuberculosis, which may be relevant for treating parasitic diseases without inducing resistance in M. tuberculosis in co-exposed patients. For example, nitroimidazopyrazinones and nitroimidazopyrazines, particularly $24 \mathrm{c}$ and $24 \mathrm{e}\left(\mathrm{R}^{2}=\mathrm{Ph}\right)$ 
and $25 \mathrm{~h}, \mathbf{2 5 j}$, and $251-\mathrm{m}\left(\mathrm{R}^{2}=\mathrm{CH}_{3}\right)$, were active against $G$. lamblia $\left(\mathrm{IC}_{50}=1.9-5.7 \mu \mathrm{M}\right)$ and T. b. brucei $\left(\mathrm{IC}_{50}=0.56-2.1\right.$ $\mu \mathrm{M}$ ) but not $M$. tuberculosis ( $\mathrm{MIC}>32 \mu \mathrm{g} / \mathrm{mL}$ ).

In general, these new subclasses displayed desirable therapeutic properties. Low cytotoxicity against mammalian cell lines was observed generally $\left(\mathrm{CC}_{50}>100 \mu \mathrm{M}\right)$ for both series. In addition, many of the potent derivatives were stable in human and mouse liver microsomes, although the nitroimidazopyrazine series was metabolized, particularly in MLM, and when $R^{2}$ and $R^{3}$ were methyl substituents. Selected derivatives also gave similar results to 6 in plasma stability, $\mathrm{PPB}$, and Caco-2 intestinal permeability assays. Like other early stage antitubercular leads including bicyclic nitroimidazoles, solubility was identified as an important parameter for future optimization. While a number of active compounds against T. b. brucei had moderate solubility, the most potent antitubercular compounds had poor aqueous kinetic solubility $(<10 \mu \mathrm{M})$. Optimization of the $\mathrm{R}^{1}, \mathrm{R}^{2}$, and $\mathrm{R}^{3}$ sites, particularly the $\mathrm{R}^{1}$ site, to arrive at more potent compounds, while maintaining desirable drug-like properties and improving the solubility will be explored in future studies.

This study lays the foundation for future work focused on determining and optimizing the efficacy of selected derivatives in in vivo models of M. tuberculosis, G. lamblia, and T. b. brucei and understanding their mode of action in these pathogens. These studies are expected to provide further insight into nitroimidazole activation and guide the development of bicyclic nitroimidazoles with therapeutic potential against both $M$. tuberculosis and a wide range of parasitic organisms.

\section{EXPERIMENTAL SECTION}

General Information. Reagents and anhydrous solvents were used as received. Reactions requiring anhydrous conditions were performed under an inert atmosphere of nitrogen. Reactions were monitored by thin-layer chromatography (TLC) or LCMS. Analytical TLC was performed on Merck TLC aluminum sheets pre-coated with Silica Gel 60 F-254 and compounds were visualized using a $\mathrm{UV}_{254}$ lamp and potassium permanganate stain. Melting points were determined using a Gallenkamp melting point apparatus and are corrected to a standard curve of the measured and literature melting points of vanillin, acetyl salicylic acid, 3-phenoxybenzoic acid, and caffeine standards. Analytical LCMS was performed on a Shimadzu LCMS using $0.05 \%$ formic acid in water as solvent A and $0.05 \%$ formic acid in acetonitrile as solvent B. Standard conditions unless otherwise specified: column Zorbax Eclipse XDB-Phenyl, $3.0 \times 100$ $\mathrm{mm}, 3.5 \mu$. Alternative column: Waters Atlantis T3, $3.0 \times 100 \mathrm{~mm}, 3$ $\mu$. For detection, PDA UV, evaporative light scattering detector (ELSD), and electrospray MS were used. Compounds were purified by MPLC (Biotage Isolera or Grace Reveleris X2 chromatography systems) or by HPLC (Agilent Preparative HPLC 1260 Infinity Series). Commercially available cartridges were used for MPLC chromatography (Biotage SNAP cartridge HP-Silica 10, 25 or $50 \mathrm{~g}$, Reveleris $4 \mathrm{~g}$ or $12 \mathrm{~g}$ silica $(40 \mu \mathrm{m})$ cartridge or Reveleris C18 reversed-phase $12 \mathrm{~g}$ cartridge). Column for HPLC: Agilent XDB Phenyl $5 \mu \mathrm{m}, 30 \times 100 \mathrm{~mm}$. All products tested for biological activity were obtained in $>95 \%$ purity as determined by HPLC using UV at $254 \mathrm{~nm}$, ESIMS, and ELSD detection. NMR data were collected and calibrated in DMSO- $d_{6}$ or $\mathrm{CDCl}_{3}$ with $0.05 \%$ TMS at $298 \mathrm{~K}$ on a Varian Unity $400 \mathrm{MHz}$ or Bruker AVANCE- $600 \mathrm{MHz}$ spectrometer. Where appropriate, ${ }^{1} \mathrm{H}$-coupling constants were examined using resolution enhancement with MestReNova software. High-resolution MS (HRMS) was performed on a Bruker micrOTOF mass spectrometer using (+)-ESI calibrated to HCOONa. For compounds purified by reverse phase chromatography, the exact concentration of the compounds for assay was determined by the quantitative NMR integration "PULCON" experiment. ${ }^{48}$ These settings were used for all
PULCON experiments: relaxation delay of $30 \mathrm{~s}, 8$ scans, 2 dummy scans, $90^{\circ}$ pulse and temperature at $298 \mathrm{~K}$. The mass calculated from PULCON experiments was used to calculate the reaction percentage yields.

General Procedure A: Alkylation of Imidazole and Imidazopyrazinones. To a stirred solution of imidazole/imidazopyrazinone (1 equiv) in anh. DMF $(15-30 \mathrm{vol})$ was added $\mathrm{K}_{2} \mathrm{CO}_{3}$ or $\mathrm{Cs}_{2} \mathrm{CO}_{3}$ (3 equiv) followed by alkyl or benzyl halide (1.2-1.5 equiv). The reaction was stirred at $\mathrm{rt}$ or heated in a microwave reactor at 80$180{ }^{\circ} \mathrm{C}$ for $15 \mathrm{~min}$ and monitored by LCMS. If necessary, an additional portion of alkylating agent $(0.5-1.5$ equiv) was added and the reaction was heated at $\mu \mathrm{W} 120-180{ }^{\circ} \mathrm{C}$ for a further $15 \mathrm{~min}$ to consume the imidazole starting material. The work-up procedure $\mathrm{A}$ is as follows: the reaction was poured into $\mathrm{H}_{2} \mathrm{O}$ and extracted with EtOAc. The combined organic layers were washed with brine, dried over $\mathrm{MgSO}_{4}$, and filtered. Volatiles were removed in vacuo to give the crude product. The work-up procedure $\mathrm{B}$ is as follows: the reaction was poured into water and the precipitate was collected by filtration, washed with water, and dried in vacuo.

General Procedure B: Alkylation of Imidazopyrazinones. To a stirred suspension of imidazopyrazinone (1 equiv) in toluene (20 vol) was added $\mathrm{Ag}_{2} \mathrm{CO}_{3}$ (1.2 equiv) followed by benzyl halide (2 equiv). The reaction was heated at $80{ }^{\circ} \mathrm{C}$ overnight and monitored by LCMS. The general aqueous work up is as follows: the reaction was poured into $\mathrm{H}_{2} \mathrm{O}$ and extracted with EtOAc. The combined organic layers were washed with brine, dried over $\mathrm{MgSO}_{4}$, and filtered. Volatiles were removed in vacuo to give the crude product.

General Procedure C: Ring Closure to Synthesize Imidazopyrazinones. To a stirred solution of 4-nitroimidazole (1 equiv) in 1,4-dioxane $(10 \mathrm{vol})$ was added $2 \mathrm{M}$ aq $\mathrm{HCl}(10 \mathrm{vol})$. The reaction was heated at $120{ }^{\circ} \mathrm{C}$ for $30 \mathrm{~min}$ in the microwave. The work-up procedure $\mathrm{A}$ is as follows: the crystalline solid was collected by vacuum filtration. The precipitate was washed with water and dried in vacuo to give a solid. The work-up procedure B is as follows: after heating the reaction, the volatiles were evaporated in vacuo to yield a crude material that was purified by recrystallization or chromatography.

General Procedure D: Deprotection of the AcetateProtecting Group. Anh. $\mathrm{K}_{2} \mathrm{CO}_{3}$ (1.5 equiv) was added to a stirred suspension of ethyl acetate imidazopyrazinone (1 equiv) in $\mathrm{MeOH}$ $(20 \mathrm{vol})$. After $1 \mathrm{~h}$, volatiles were removed under a stream of $\mathrm{N}_{2}$. The solid was suspended with $\mathrm{H}_{2} \mathrm{O}$, filtered, washed with water, and dried under vacuum. The work-up procedure $\mathrm{B}$ is as follows: the reaction was acidified with a $5 \%$ solution of trifluoroacetic acid (TFA) in $\mathrm{MeOH}$. The suspension was then concentrated onto $\mathrm{C} 18$ silica gel and purified by MPLC.

General Procedure E: Two Step, One-Pot Synthesis of Imidazopyrazinones. The alkylating agent $(1.2-1.5$ equiv) was added slowly to a stirred suspension of 13 a ( 1 equiv), anh. $\mathrm{K}_{2} \mathrm{CO}_{3}(3$ equiv) in anh. DMF (15 vol). The reaction was stirred at rt until complete $(10 \mathrm{~min}$ to $5 \mathrm{~h}$ ), and $2 \mathrm{M}$ aq $\mathrm{HCl}(15 \mathrm{vol})$ was then added slowly to control effervescence $\left(\mathrm{CO}_{2}\right)$. The reaction was then stirred at $\mathrm{rt}$ (overnight to 4 days) or for 22a heated with microwave irradiation until the cyclization was complete. The solid precipitate was collected by vacuum filtration, washed with water and $\mathrm{MeOH}$, and then dried in vacuo.

N-Benzyl-5-nitro-1H-imidazole-2-carboxamide; $16 b$. The title compound was prepared according to the procedure reported by Jarrad et al.; ${ }^{28}$ amine: benzylamine $(300 \mu \mathrm{L}, 2.74 \mathrm{mmol})$. The crude material was purified over silica gel by MPLC (Biotage 20-100\% EtOAc in pet. spirits gradient) to yield a colorless solid (399 mg, $71 \%)$. LCMS: $R_{\mathrm{t}}=3.13 \mathrm{~min}, 99 \mathrm{~A} \%$ @ $254 \mathrm{~nm},[\mathrm{M}-\mathrm{H}]^{-}=245.0$. ${ }^{1} \mathrm{H}$ NMR $\left(600 \mathrm{MHz}\right.$, DMSO- $\left.d_{6}\right): \delta 14.31(\mathrm{~s}, 1 \mathrm{H}), 9.45(\mathrm{t}, J=6.4 \mathrm{~Hz}$, $1 \mathrm{H}), 8.46(\mathrm{~s}, 1 \mathrm{H}), 7.31(\mathrm{~d}, J=4.4 \mathrm{~Hz}, 4 \mathrm{H}), 7.27-7.20(\mathrm{~m}, 1 \mathrm{H}), 4.43$ $(\mathrm{d}, J=6.4 \mathrm{~Hz}, 2 \mathrm{H}) .{ }^{13} \mathrm{C}$ NMR $\left(150 \mathrm{MHz}, \mathrm{DMSO}-d_{6}\right): \delta 157.2,146.8$, $139.7,139.1,128.3,127.4,126.9,121.6,42.3$. HRMS (ESI) $\mathrm{m} / \mathrm{z}$ : calcd for $\mathrm{C}_{11} \mathrm{H}_{10} \mathrm{~N}_{4} \mathrm{NaO}_{3}[\mathrm{M}+\mathrm{Na}]^{+}$, 269.0645; found, 269.0639.

$\mathrm{N}$-(4-Methylbenzyl)-5-nitro-1H-imidazole-2-carboxamide; $16 \mathrm{~d}$. It was prepared according to the procedure reported by Jarrad et al.; ${ }^{28}$ amine: 4-methylbenzylamine $(155 \mu \mathrm{L}, 1.37 \mathrm{mmol})$. The crude 
material was purified over silica gel by MPLC (Grace Reveleris X2, $20-100 \%$ EtOAc in pet. spirits gradient) to obtain a yellow solid (201 mg, 68\%). LCMS: $R_{\mathrm{t}}=3.27 \mathrm{~min}, 99 \mathrm{~A} \%$ @ $254 \mathrm{~nm},[\mathrm{M}-\mathrm{H}]^{-}=$ 259.0. ${ }^{1} \mathrm{H}$ NMR $\left(600 \mathrm{MHz}, \mathrm{DMSO}-d_{6}\right): \delta 14.30(\mathrm{~s}, 1 \mathrm{H}), 9.37(\mathrm{t}, J=$ $6.4 \mathrm{~Hz}, 1 \mathrm{H}), 8.43(\mathrm{~s}, 1 \mathrm{H}), 7.20(\mathrm{~d}, J=8.2 \mathrm{~Hz}, 2 \mathrm{H}), 7.11(\mathrm{~d}, J=7.8$ $\mathrm{Hz}, 2 \mathrm{H}), 4.37(\mathrm{~d}, J=6.4 \mathrm{~Hz}, 2 \mathrm{H}), 2.26(\mathrm{~s}, 3 \mathrm{H}) .{ }^{13} \mathrm{C} \mathrm{NMR}(150 \mathrm{MHz}$, DMSO- $\left.d_{6}\right): \delta 157.2,146.8,140.0,136.1,135.9,128.8,127.4,121.8$, 42.0, 20.7. HRMS (ESI) $\mathrm{m} / z$ : calcd for $\mathrm{C}_{12} \mathrm{H}_{12} \mathrm{~N}_{4} \mathrm{NaO}_{3}[\mathrm{M}+\mathrm{Na}]^{+}$, 283.0802; found, 283.0794 .

2-Nitroimidazo[1,2-a]pyrazin-8(7H)-one; 17a. To a stirred suspension of 19a $(551 \mathrm{mg}, 2.02 \mathrm{mmol})$ in $\mathrm{H}_{2} \mathrm{O}(11 \mathrm{~mL})$ was added $5 \%$ aq $\mathrm{HCl}(1.44 \mathrm{~mL}, 1$ equiv). The reaction was refluxed for $4.5 \mathrm{~h}$. The solvent was removed in vacuo. The crude product was purified by recrystallization (slurry equilibration with hot $\mathrm{MeOH}$ ) to give fine off-white needles $(241 \mathrm{mg}, 66 \%) . \mathrm{mp}=350{ }^{\circ} \mathrm{C}$ (decomposed). LCMS: $R_{\mathrm{t}}=1.49 \mathrm{~min}, 99 \mathrm{~A} \% @ 254 \mathrm{~nm},[\mathrm{M}+$ $\mathrm{H}]^{+}=180.8$. ${ }^{1} \mathrm{H}$ NMR $\left(600 \mathrm{MHz}, \mathrm{DMSO}-d_{6}\right): \delta 11.58(\mathrm{~s}, 1 \mathrm{H}), 8.81$ $(\mathrm{s}, 1 \mathrm{H}), 7.50(\mathrm{~d}, J=5.6 \mathrm{~Hz}, 1 \mathrm{H}), 7.07(\mathrm{~d}, J=5.7 \mathrm{~Hz}, 1 \mathrm{H}) .{ }^{13} \mathrm{C} \mathrm{NMR}$ $\left(150 \mathrm{MHz}, \mathrm{DMSO}-d_{6}\right): \delta 153.2,147.6,135.5,119.8,116.6,107.1$. The position of the nitro group was confirmed by HMBC and X-ray crystallography. X-ray diffraction data were collected on Oxford Diffraction Gemini Ultra dual source (Mo and $\mathrm{Cu}$ ) CCD Diffractometer with $\mathrm{Cu}$ radiation $(\lambda=1.54184 \AA), T=190(2) \mathrm{K}$. Additional crystallographic data and HMBC data are available in the Supporting Information, Figure S1 and Tables S1-S3. HRMS (ESI) $m / z$ : calcd for $\mathrm{C}_{12} \mathrm{H}_{8} \mathrm{~N}_{8} \mathrm{NaO}_{6}[2 \mathrm{M}+\mathrm{Na}]^{+}, 383.0459$; found, 383.0454 .

7-Benzyl-2-nitroimidazo[1,2-a]pyrazin-8(7H)-one; 17b. Compound $19 \mathrm{~b}(150 \mathrm{mg}, 0.414 \mathrm{mmol})$ was reacted according to general procedure $\mathrm{C}$, work-up procedure $\mathrm{B}$. The crude material was purified by recrystallization (hot slurry from $\mathrm{DCM} / \mathrm{MeOH}$ ) to yield a tan solid $(88 \mathrm{mg}, 78 \%) . \mathrm{mp}=298-299^{\circ} \mathrm{C}$ (decomposed). LCMS: $R_{\mathrm{t}}=$ $3.17 \mathrm{~min}, 99 \mathrm{~A} \% @ 254 \mathrm{~nm},[\mathrm{M}+\mathrm{H}]^{+}=271.0 .{ }^{1} \mathrm{H}$ NMR $(600 \mathrm{MHz}$, DMSO- $\left.d_{6}\right): \delta 8.81(\mathrm{~s}, 1 \mathrm{H}), 7.60(\mathrm{~d}, J=5.9 \mathrm{~Hz}, 1 \mathrm{H}), 7.42(\mathrm{~d}, J=5.9$ $\mathrm{Hz}, 1 \mathrm{H}), 7.37-7.34(\mathrm{~m}, 4 \mathrm{H}), 7.32-7.24(\mathrm{~m}, 1 \mathrm{H}), 5.13(\mathrm{~s}, 2 \mathrm{H}) .{ }^{13} \mathrm{C}$ NMR $\left(150 \mathrm{MHz}, \mathrm{DMSO}-d_{6}\right): \delta 152.8,148.0,136.5,135.2,128.7$, $127.8,127.7,123.6,116.7,107.4,50.2$. HRMS (ESI) $\mathrm{m} / z$ : calcd for $\mathrm{C}_{13} \mathrm{H}_{10} \mathrm{~N}_{4} \mathrm{NaO}_{3}[\mathrm{M}+\mathrm{Na}]^{+}$, 293.0645; found, 293.0640.

2-Nitro-7-(4-(trifluoromethoxy)benzyl)imidazo[1,2-a]pyrazin$8(7 \mathrm{H})$-one; 17c. Compound 19c $(300 \mathrm{mg}, 0.672 \mathrm{mmol})$ was reacted according to general procedure $\mathrm{C}$, work-up procedure $\mathrm{A}$, to yield a lemon yellow crystalline solid $(207 \mathrm{mg}, 87 \%) . \mathrm{mp}=264-266{ }^{\circ} \mathrm{C}$ (decomposed). LCMS: $R_{\mathrm{t}}=3.47 \mathrm{~min}, 99 \mathrm{~A} \% @ 254 \mathrm{~nm},[\mathrm{M}+\mathrm{H}]^{+}=$ 355.0. ${ }^{1} \mathrm{H}$ NMR $\left(600 \mathrm{MHz}, \mathrm{DMSO}-d_{6}\right): \delta 8.82(\mathrm{~s}, 1 \mathrm{H}), 7.62(\mathrm{~d}, J=$ $5.9 \mathrm{~Hz}, 1 \mathrm{H}), 7.52-7.47(\mathrm{~m}, 2 \mathrm{H}), 7.46(\mathrm{~d}, J=5.9 \mathrm{~Hz}, 1 \mathrm{H}), 7.39-7.33$ $(\mathrm{m}, 2 \mathrm{H}), 5.16(\mathrm{~s}, 2 \mathrm{H}) .{ }^{13} \mathrm{C}$ NMR $\left(150 \mathrm{MHz}, \mathrm{DMSO}-d_{6}\right): \delta 152.8$, $148.0,147.7,136.0,135.1,129.7,123.5,121.2,120.0$ (q, $J=257.6$ $\mathrm{Hz}), 116.6,107.5,49.6$. HRMS (ESI) $m / z$ : calcd for $\mathrm{C}_{14} \mathrm{H}_{9} \mathrm{~F}_{3} \mathrm{~N}_{4} \mathrm{NaO}_{4}$ $[\mathrm{M}+\mathrm{Na}]^{+}, 377.0468$; found, 377.0467 .

7-(4-Methylbenzyl)-2-nitroimidazo[1,2-a]pyrazin-8(7H)-one; 17d. Compound $19 \mathrm{~d}(100 \mathrm{mg}, 0.266 \mathrm{mmol})$ was reacted according to general procedure $\mathrm{C}$, work-up procedure $\mathrm{B}$. The crude material was purified by recrystallization (slurry equilibration with hot DCM/ $\mathrm{MeOH})$ to yield a tan solid $(53 \mathrm{mg}, 70 \%) . \mathrm{mp}=311-312{ }^{\circ} \mathrm{C}$ (decomposed). LCMS: $R_{\mathrm{t}}=3.30 \mathrm{~min}, 99 \mathrm{~A} \% @ 254 \mathrm{~nm},[\mathrm{M}+\mathrm{H}]^{+}=$ 285.1. ${ }^{1} \mathrm{H}$ NMR $\left(600 \mathrm{MHz}, \mathrm{DMSO}-d_{6}\right): \delta 8.80(\mathrm{~s}, 1 \mathrm{H}), 7.58(\mathrm{~d}, J=$ $5.9 \mathrm{~Hz}, 1 \mathrm{H}), 7.39(\mathrm{~d}, J=5.9 \mathrm{~Hz}, 1 \mathrm{H}), 7.27-7.22(\mathrm{~m}, 2 \mathrm{H}), 7.18-7.13$ $(\mathrm{m}, 2 \mathrm{H}), 5.07(\mathrm{~s}, 2 \mathrm{H}), 2.27(\mathrm{~s}, 3 \mathrm{H}) .{ }^{13} \mathrm{C}$ NMR $(151 \mathrm{MHz}, \mathrm{DMSO}-$ $\left.d_{6}\right): \delta 152.7,148.0,137.1,135.1,133.5,129.2,127.8,123.5,116.6$, 107.4, 49.9, 20.7. HRMS (ESI) $m / z$ : calcd for $\mathrm{C}_{14} \mathrm{H}_{13} \mathrm{~N}_{4} \mathrm{O}_{3}[\mathrm{M}+\mathrm{H}]^{+}$, 285.0982; found, 285.0973 .

7-(4-Fluorobenzyl)-2-nitroimidazo[1,2-a]pyrazin-8(7H)-one; 17e. Compound $19 \mathrm{e}(384 \mathrm{mg}, 1.01 \mathrm{mmol})$ was reacted according to the general procedure $\mathrm{C}$, work-up procedure $\mathrm{A}$, to yield a yellow crystalline solid $(249 \mathrm{mg}, 86 \%) . \mathrm{mp}=297^{\circ} \mathrm{C}$ (decomposed). LCMS: $R_{\mathrm{t}}=3.23 \mathrm{~min}, 98 \mathrm{~A} \% @ 254 \mathrm{~nm},[\mathrm{M}+\mathrm{H}]^{+}=289.0 .{ }^{1} \mathrm{H}$ NMR $(600$ MHz, DMSO- $\left.d_{6}\right): \delta 8.81(\mathrm{~s}, 1 \mathrm{H}), 7.60(\mathrm{~d}, J=5.9 \mathrm{~Hz}, 1 \mathrm{H}), 7.44(\mathrm{~d}, J$ $=5.9 \mathrm{~Hz}, 1 \mathrm{H}), 7.44-7.39(\mathrm{~m}, 2 \mathrm{H}), 7.23-7.15(\mathrm{~m}, 2 \mathrm{H}), 5.11(\mathrm{~s}, 2 \mathrm{H})$. ${ }^{13} \mathrm{C}$ NMR $\left(150 \mathrm{MHz}\right.$, DMSO- $\left.d_{6}\right): \delta 161.7(\mathrm{~d}, J=243.9 \mathrm{~Hz}), 152.8$, 148.0, 135.1, 132.7, 130.0 (d, $J=8.6 \mathrm{~Hz}), 123.4,116.6,115.4$ (d, $J=$
$20.1 \mathrm{~Hz}$ ), 107.4, 49.5. HRMS (ESI) $m / z$ : calcd for $\mathrm{C}_{13} \mathrm{H}_{9} \mathrm{FN}_{4} \mathrm{NaO}_{3}$ $[\mathrm{M}+\mathrm{Na}]^{+}, 311.0551$; found, 311.0551 .

2-Nitro-7-(3-(trifluoromethoxy)benzyl)imidazo[1,2-a]pyrazin$8(7 H)$-one; 17f. Compound 19f (100 mg, $0.224 \mathrm{mmol})$ was reacted according to general procedure $\mathrm{C}$, work-up procedure $\mathrm{B}$. The crude material was purified by recrystallization (DCM/EtOH) with hot filtration to obtain a colorless pearlescent solid (33 mg, 42\%). $\mathrm{mp}=$ 230-231 ${ }^{\circ} \mathrm{C}$ (decomposed). LCMS: $R_{\mathrm{t}}=3.45 \mathrm{~min}, 99 \mathrm{~A} \%$ @ 254 $\mathrm{nm},[\mathrm{M}+\mathrm{H}]^{+}=355.0 .{ }^{1} \mathrm{H}$ NMR $\left(600 \mathrm{MHz}, \mathrm{DMSO}-d_{6}\right): \delta 8.82(\mathrm{~s}$, $1 \mathrm{H}), 7.61(\mathrm{~d}, J=5.8 \mathrm{~Hz}, 1 \mathrm{H}), 7.49(\mathrm{t}, J=7.9 \mathrm{~Hz}, 1 \mathrm{H}), 7.45(\mathrm{~d}, J=5.9$ $\mathrm{Hz}, 1 \mathrm{H}), 7.41-7.38(\mathrm{~m}, 1 \mathrm{H}), 7.37$ (ddd, $J=7.5,1.6,0.7 \mathrm{~Hz}, 1 \mathrm{H})$, 7.33-7.28 (m, 1H), $5.17(\mathrm{~s}, 2 \mathrm{H}) .{ }^{13} \mathrm{C}$ NMR (150 MHz, DMSO-d 6 ): $\delta 152.9,148.5,148.0,139.3,135.2,130.7,126.7,123.5,120.3,120.2$, $120.1(\mathrm{q}, J=257.2 \mathrm{~Hz}), 116.7,107.6,49.8$. HRMS (ESI) $\mathrm{m} / z$ : calcd for $\mathrm{C}_{14} \mathrm{H}_{9} \mathrm{~F}_{3} \mathrm{~N}_{4} \mathrm{NaO}_{4}[\mathrm{M}+\mathrm{Na}]^{+}$, 377.0468; found, 377.0471.

7-(3-Methylbenzyl)-2-nitroimidazo[1,2-a]pyrazin-8(7H)-one; 17g. Compound $17 \mathrm{a}(70 \mathrm{mg}, 0.389 \mathrm{mmol})$ was reacted according to general procedure $\mathrm{B}$. The crude material contained imidazopyrazinone (major) and imidazopyrazine (minor) isomers in a ratio of 2:1 as detected by LC-MS (UV $254 \mathrm{~nm}$ ). The crude was partially purified over silica gel by MPLC (Biotage Isolera, $0-6 \% \mathrm{DCM} / \mathrm{MeOH}$ ), then purified over C18-reversed phase silica (Grace Reveleris X2, A: $\mathrm{H}_{2} \mathrm{O}+$ $0.1 \%$ TFA, B: ACN $+0.1 \%$ TFA, $0-100 \%$ B) to yield imidazopyrazinone $17 \mathrm{~g}$ as white powder $(11 \mathrm{mg}, 7 \%)$ and imidazopyrazine $\mathbf{1 8 g}$ as white powder $(9 \mathrm{mg}, 7 \%)$. Major isomer imidazopyrazinone 17g: LCMS: $R_{\mathrm{t}}=3.25 \mathrm{~min}, 99 \mathrm{~A} \% @ 254 \mathrm{~nm},[\mathrm{M}$ $+\mathrm{H}]^{+}=285.1 .{ }^{1} \mathrm{H}$ NMR $\left(600 \mathrm{MHz}, \mathrm{DMSO}-d_{6}\right): \delta 8.81(\mathrm{~s}, 1 \mathrm{H}), 7.59$ $(\mathrm{d}, J=5.9 \mathrm{~Hz}, 1 \mathrm{H}), 7.40(\mathrm{~d}, J=5.9 \mathrm{~Hz}, 1 \mathrm{H}), 7.24(\mathrm{t}, J=7.6 \mathrm{~Hz}, 1 \mathrm{H})$, 7.18-7.09 (m, 3H), 5.09 (s, 2H), 2.28 (s 3H). ${ }^{13} \mathrm{C}$ NMR (150 MHz, DMSO- $\left.d_{6}\right): \delta 152.7,148.0,137.9,136.4,135.1,128.5,128.4,128.2$, 124.8, 123.5, 116.6, 107.3, 50.1, 20.9. HRMS (ESI) $\mathrm{m} / z$ : calcd for $\mathrm{C}_{14} \mathrm{H}_{12} \mathrm{~N}_{4} \mathrm{O}_{3} \mathrm{Na}[\mathrm{M}+\mathrm{Na}]^{+}$, 307.0802; found, 307.0800. Characterization data of $18 \mathrm{~g}$ are listed below following compounds $17 \mathrm{a}-\mathbf{t}$.

2-Nitro-7-(3-(trifluoromethyl)benzyl)imidazo[1,2-a]pyrazin$8(7 \mathrm{H})$-one; $17 \mathrm{~h}$. Compound $17 \mathrm{a}(70 \mathrm{mg}, 0.389 \mathrm{mmol})$ was reacted with $\mathrm{Cs}_{2} \mathrm{CO}_{3}$ and 3-(trifluoromethyl)benzyl bromide (1.2 equiv) according to general procedure $\mathrm{A}$ at $\mu \mathrm{W} 100^{\circ} \mathrm{C}(15 \mathrm{~min})$, work-up $\mathrm{B}$. The crude material containing imidazopyrazinone (major) and imidazopyrazine (minor) isomers was detected in a ratio of 10.1:1 by LC-MS (UV $254 \mathrm{~nm}$ ). The crude material was purified over silica gel by MPLC (Biotage Isolera, $0-5 \% \mathrm{DCM} / \mathrm{MeOH}$ ) to give final products imidazopyrazinone $\mathbf{1 7 h}$ as white powder $(11 \mathrm{mg}, 7 \%)$ and imidazopyrazine $18 \mathrm{~h}$ as white powder $(9 \mathrm{mg}, 7 \%)$. Major isomer imidazopyrazinone $17 \mathrm{~h}$ (cream powder, $72 \mathrm{mg}$, 55\%): LCMS: $R_{\mathrm{t}}=$ $2.95 \mathrm{~min}, 99 \mathrm{~A} \% @ 254 \mathrm{~nm},[\mathrm{M}+\mathrm{H}]^{+}=339.1 ;{ }^{1} \mathrm{H}$ NMR $(600 \mathrm{MHz}$, DMSO- $\left.d_{6}\right): \delta 8.82(\mathrm{~s}, 1 \mathrm{H}), 7.77(\mathrm{~d}, J=1.7 \mathrm{~Hz}, 1 \mathrm{H}), 7.67(\mathrm{dd}, J=$ $12.3,7.4 \mathrm{~Hz}, 2 \mathrm{H}), 7.63-7.58(\mathrm{~m}, 2 \mathrm{H}), 7.48(\mathrm{~d}, J=5.9 \mathrm{~Hz}, 1 \mathrm{H}), 5.22$ $(\mathrm{s}, 2 \mathrm{H}) ;{ }^{13} \mathrm{C}$ NMR $\left(150 \mathrm{MHz}, \mathrm{DMSO}-d_{6}\right): \delta 152.9,148.0,137.9$, $135.2,131.9,129.7,129.3(\mathrm{q}, J=31.8 \mathrm{~Hz}), 124.5,124.5,124.1(\mathrm{q}, J=$ $272.2 \mathrm{~Hz}$ ), 123.5, 116.7, 107.6, 49.9. HRMS (ESI) $\mathrm{m} / z$ : calcd for $\mathrm{C}_{14} \mathrm{H}_{9} \mathrm{~F}_{3} \mathrm{~N}_{4} \mathrm{O}_{3} \mathrm{Na}[\mathrm{M}+\mathrm{Na}]^{+}$, 361.0519; found, 361.0517. Characterization data of $18 \mathrm{~h}$ are listed below following compounds $17 \mathrm{a}-\mathbf{t}$.

2-Nitro-7-(2-(trifluoromethoxy)benzyl)imidazo[1,2-a]pyrazin$8(7 \mathrm{H})$-one; 17i. Compound $17 \mathrm{a}(70 \mathrm{mg}, 0.389 \mathrm{mmol})$ was reacted according to general procedure $\mathrm{B}$. The crude material contained imidazopyrazinone (major) and imidazopyrazine (minor) isomers in a ratio of $1.9: 1$ as detected by LC-MS (UV $254 \mathrm{~nm}$ ). The crude material was purified over C18-reversed phase silica (Grace Reveleris $\mathrm{X} 2$, A: $\mathrm{H}_{2} \mathrm{O}+0.1 \%$ TFA, $\mathrm{B}: \mathrm{ACN}+0.1 \%$ TFA, $\left.30-80 \% \mathrm{~B}\right)$ to give the final product: Major isomer imidazopyrazinone 17i (cream powder, $20 \mathrm{mg}$, 5\%): LCMS: $R_{\mathrm{t}}=2.95 \mathrm{~min}, 98 \mathrm{~A} \% @ 254 \mathrm{~nm},[\mathrm{M}+$ $\mathrm{H}]^{+}=355.1 ;{ }^{1} \mathrm{H}$ NMR $\left(600 \mathrm{MHz}, \mathrm{DMSO}-d_{6}\right): \delta 8.84(\mathrm{~s}, 1 \mathrm{H}), 7.63$ $(\mathrm{d}, J=5.9 \mathrm{~Hz}, 1 \mathrm{H}), 7.47(\mathrm{ddd} J=8.2,7.1,1.8 \mathrm{~Hz}, 1 \mathrm{H}), 7.42(\mathrm{dt}, J=$ 8.2, $1.6 \mathrm{~Hz}, 1 \mathrm{H}), 7.39-7.27(\mathrm{~m}, 3 \mathrm{H}), 5.21(\mathrm{~s}, 2 \mathrm{H}) ;{ }^{13} \mathrm{C}$ NMR $(150$ $\left.\mathrm{MHz}, \mathrm{DMSO}-d_{6}\right): \delta 152.7,148.0,146.2,135.1,129.7,129.5,128.5$, 127.6, 123.6, 120.5, $120.2(\mathrm{q}, J=257.1 \mathrm{~Hz}), 116.7,107.5,45.7$. HRMS (ESI) $m / z$ : calcd for $\mathrm{C}_{14} \mathrm{H}_{9} \mathrm{~F}_{3} \mathrm{~N}_{4} \mathrm{O}_{4} \mathrm{Na}[\mathrm{M}+\mathrm{Na}]^{+}$, 377.0468; found, 377.0469. Mixed fractions were combined and purified over silica gel by MPLC (Biotage Isolera, $0-6 \% \mathrm{DCM} / \mathrm{MeOH}$ ) to yield minor isomer imidazopyrazine $\mathbf{1 8 i}$ (white powder, $11 \mathrm{mg}, 3 \%$ ). 
Characterization data of $\mathbf{1 8} \mathbf{i}$ are listed below following compounds $17 \mathbf{a}-\mathbf{t}$

7-(2,4-Difluorobenzyl)-2-nitroimidazo[1,2-a]pyrazin-8(7H)-one; 17j. Compound $17 \mathrm{a}(50 \mathrm{mg}, 0.278 \mathrm{mmol})$ was reacted with $\mathrm{Cs}_{2} \mathrm{CO}_{3}$ and 2,4-difluorobenzyl bromide (1.2 equiv) according to general procedure $\mathrm{A}$ at $\mathrm{rt}$ for $1 \mathrm{~h}$, with work-up procedure $\mathrm{B}$. The crude product was purified by recrystallization (slurry equilibration with hot $\mathrm{DCM} / \mathrm{EtOH}$ ) to yield the final product imidazopyrazinone $\mathbf{1 7} \mathbf{j}$ as a white powder (64 mg, 75\%). LCMS: $R_{\mathrm{t}}=2.79 \mathrm{~min}, 99 \mathrm{~A} \%$ @ 254 $\mathrm{nm},[\mathrm{M}+\mathrm{H}]^{+}=307.1 ;{ }^{1} \mathrm{H}$ NMR $\left(600 \mathrm{MHz}, \mathrm{DMSO}-d_{6}\right): \delta 8.82(\mathrm{~s}$, $1 \mathrm{H}), 7.61(\mathrm{~d}, J=5.9 \mathrm{~Hz}, 1 \mathrm{H}), 7.43(\mathrm{td}, J=8.7,6.5 \mathrm{~Hz}, 1 \mathrm{H}), 7.37$ (d, $J$ $=5.9 \mathrm{~Hz}, 1 \mathrm{H}), 7.30(\mathrm{ddd}, 10.7,9.3,2.6 \mathrm{~Hz}, 1 \mathrm{H}), 7.10-7.06(\mathrm{~m}, 1 \mathrm{H})$, $5.14(\mathrm{~s}, 2 \mathrm{H}) ;{ }^{13} \mathrm{C}$ NMR $\left(150 \mathrm{MHz}\right.$, DMSO- $\left.d_{6}\right): \delta 161.9$ (dd, $J=$ $246.9,12.2 \mathrm{~Hz}), 160.3(\mathrm{dd}, J=247.9,12.2 \mathrm{~Hz}), 152.7,148.0,135.0$, $131.5(\mathrm{dd}, J=10.3,5.6 \mathrm{~Hz}), 123.6,119.5(\mathrm{dd}, J=15.2,3.9 \mathrm{~Hz})$, $116.7,111.6(\mathrm{dd}, J=21.4,3.2 \mathrm{~Hz}), 107.4,104.0(\mathrm{t}, J=25.7 \mathrm{~Hz}), 44.6$ $\left(\mathrm{d}, J=3.2 \mathrm{~Hz}\right.$ ). HRMS (ESI) $\mathrm{m} / z$ : calcd for $\mathrm{C}_{13} \mathrm{H}_{8} \mathrm{~F}_{2} \mathrm{~N}_{4} \mathrm{O}_{3} \mathrm{Na}[\mathrm{M}+$ $\mathrm{Na}]^{+}, 329.0457$; found, 329.0449 .

2-Nitro-7-(pyridin-2-ylmethyl)imidazo[1,2-a]pyrazin-8(7H)-one, 1TFA; 17k. Compound 19k (150 mg, $0.413 \mathrm{mmol})$ was reacted according to general procedure $\mathrm{C}$, work-up procedure $\mathrm{B}$. The crude material was purified over $\mathrm{C} 18$ silica gel by MPLC (Grace Reveleris X2, A: $\mathrm{H}_{2} \mathrm{O}+0.1 \%$ TFA, B: ACN $+0.1 \%$ TFA, $5-30 \%$ B) to yield a colorless powder ( $88 \mathrm{mg}, 56 \%)$. LCMS: $R_{\mathrm{t}}=2.61 \mathrm{~min}, 99 \mathrm{~A} \%$ @ 254 $\mathrm{nm},[\mathrm{M}+\mathrm{H}]^{+}=272.0 .{ }^{1} \mathrm{H}$ NMR $\left(600 \mathrm{MHz}, \mathrm{DMSO}-d_{6}\right): \delta 8.85(\mathrm{~s}$, $1 \mathrm{H}), 8.53(\mathrm{dt}, J=4.8,1.4,1 \mathrm{H}), 7.86(\mathrm{td}, J=7.7,1.8 \mathrm{~Hz}, 1 \mathrm{H}), 7.63(\mathrm{~d}$, $J=5.9 \mathrm{~Hz}, 1 \mathrm{H}), 7.44(\mathrm{dd}, J=10.1,6.9 \mathrm{~Hz}, 2 \mathrm{H}), 7.40-7.34(\mathrm{~m}, 1 \mathrm{H})$, $5.26(\mathrm{~s}, 2 \mathrm{H}) .{ }^{13} \mathrm{C}$ NMR $\left(150 \mathrm{MHz}, \mathrm{DMSO}-d_{6}\right): \delta 155.0,152.8,148.6$, 148.0, 137.8, 135.1, 124.6, 123.1, 122.1, 116.6, 107.1, 51.8. HRMS (ESI) $\mathrm{m} / z$ : calcd for $\mathrm{C}_{12} \mathrm{H}_{9} \mathrm{~N}_{5} \mathrm{O}_{3}[\mathrm{M}+\mathrm{H}]^{+}, 272.0778$; found, 272.0782 .

7-(1-(4-Fluorophenyl)ethyl)-2-nitroimidazo[1,2-a]pyrazin-8(7H)one; 17l. Compound 191 (100 mg, $0.254 \mathrm{mmol})$ was reacted according to general procedure $\mathrm{C}$, work-up procedure $\mathrm{B}$. The crude material was purified by recrystallization $(\mathrm{DCM} / \mathrm{EtOH})$ with hot filtration to yield a colorless pearlescent solid (34 mg, 45\%). mp = 275-277 ${ }^{\circ} \mathrm{C}$ (decomposed). LCMS: $R_{\mathrm{t}}=3.31 \mathrm{~min}, 99 \mathrm{~A} \%$ @ 254 $\mathrm{nm},[\mathrm{M}+\mathrm{H}]^{+}=303.0 .{ }^{1} \mathrm{H}$ NMR $\left(600 \mathrm{MHz}, \mathrm{DMSO}-d_{6}\right): \delta 8.77(\mathrm{~s}$, $1 \mathrm{H}), 7.57(\mathrm{~d}, J=6.1 \mathrm{~Hz}, 1 \mathrm{H}), 7.47-7.41(\mathrm{~m}, 2 \mathrm{H}), 7.24-7.19(\mathrm{~m}$, $3 \mathrm{H}), 6.15(\mathrm{q}, J=7.1 \mathrm{~Hz}, 1 \mathrm{H}), 1.71(\mathrm{~d}, J=7.2 \mathrm{~Hz}, 3 \mathrm{H}) .{ }^{13} \mathrm{C}$ NMR $\left(150 \mathrm{MHz}, \mathrm{DMSO}-d_{6}\right): \delta 161.6(\mathrm{~d}, J=244.4 \mathrm{~Hz}), 152.6,148.0,136.2$ $(\mathrm{d}, J=2.90 \mathrm{~Hz}), 134.9,129.3(\mathrm{~d}, J=8.49 \mathrm{~Hz}), 119.8,116.4,115.5(\mathrm{~d}$, $J=21.3 \mathrm{~Hz}$ ), $107.8,51.6,18.4$. HRMS (ESI) $\mathrm{m} / z$ : calcd for $\mathrm{C}_{14} \mathrm{H}_{11} \mathrm{FN}_{4} \mathrm{NaO}_{3}[\mathrm{M}+\mathrm{Na}]^{+}$, 325.0707; found, 325.0718.

2-Nitro-7-(4-(trifluoromethoxy)phenethyl)imidazo[1,2-a]pyrazin-8(7H)-one; $17 \mathrm{~m}$. Imidazopyrazinone $17 \mathrm{a}(75 \mathrm{mg}, 0.42$ $\mathrm{mmol}), \mathrm{K}_{2} \mathrm{CO}_{3}$, and 1-(2-bromoethyl)-4-(trifluoromethoxy)benzene (1.2 equiv) were reacted according to general procedure $\mathrm{A}(\mu \mathrm{W} 80$ $\left.{ }^{\circ} \mathrm{C}, 30 \mathrm{~min}\right)$. The crude material contained imidazopyrazinone (major) and imidazopyrazine (minor) isomers in a 10:1 ratio $\left({ }^{1} \mathrm{H}\right.$ NMR integration). The major imidazopyrazinone isomer $17 \mathrm{~m}$ was obtained by purification of the crude residue over $\mathrm{C} 18$ silica gel (Grace Reveleris X2, A: $\mathrm{H}_{2} \mathrm{O}+0.1 \%$ TFA, B: ACN + 0.1\% TFA, 40$100 \% \mathrm{~B})$ to yield a cream solid (33 mg, 22\%). Purification of mixed fractions over silica gel by MPLC (Grace Reveleris X2, $0-7 \% \mathrm{MeOH}$ in DCM gradient) yielded an additional portion of imidazopyrazinone $\mathbf{1 7} \mathrm{m}$ as a cream solid (34 $\mathrm{mg}, 22 \%)$ and the imidazopyrazine isomer $18 \mathrm{~m}$ as a colorless solid (6 $\mathrm{mg}$, 4\%). Major isomer imidazopyrazinone 17m: LCMS: $R_{\mathrm{t}}=3.51 \mathrm{~min}, 99 \mathrm{~A} \%$ @254 nm, 95 A \% @200 nm, $[\mathrm{M}+\mathrm{H}]^{+}=369.0 .{ }^{1} \mathrm{H}$ NMR $\left(600 \mathrm{MHz}, \mathrm{DMSO}-d_{6}\right): \delta 8.79(\mathrm{~s}, 1 \mathrm{H})$, $7.54(\mathrm{~d}, J=5.8 \mathrm{~Hz}, 1 \mathrm{H}), 7.41-7.35(\mathrm{~m}, 2 \mathrm{H}), 7.29(\mathrm{~d}, J=8.0 \mathrm{~Hz}$, $2 \mathrm{H}), 7.27(\mathrm{~d}, J=5.9 \mathrm{~Hz}, 1 \mathrm{H}), 4.13(\mathrm{t}, J=7.5 \mathrm{~Hz}, 2 \mathrm{H}), 3.00(\mathrm{t}, J=7.5$ $\mathrm{Hz}, 2 \mathrm{H}) .{ }^{13} \mathrm{C}$ NMR (150 MHz, DMSO- $\left.d_{6}\right): \delta 152.6,148.0,147.0$, $137.4,135.0,130.7,123.6,121.1,120.1(\mathrm{q}, J=257.1 \mathrm{~Hz}), 116.5$, 106.8, 48.6, 33.3. HRMS (ESI) $m / z$ : calcd for $\mathrm{C}_{15} \mathrm{H}_{12} \mathrm{~F}_{3} \mathrm{~N}_{4} \mathrm{O}_{4}[\mathrm{M}+$ $\mathrm{H}^{+}$, 369.0805; found, 369.0814. Characterization data of $\mathbf{1 8 m}$ are listed below following compounds $17 \mathbf{a}-\mathbf{t}$.

7-(4-Methylphenethyl)-2-nitroimidazo[1,2-a]pyrazin-8(7H)-one; 17n. Compound $19 \mathrm{n}(100 \mathrm{mg}, 0.273 \mathrm{mmol})$ was reacted according to general procedure $\mathrm{C}$, work-up procedure $\mathrm{B}$. The crude material was purified by recrystallization (DCM/acetone) with hot filtration to yield a pearlescent tan solid (45 mg, 59\%). $\mathrm{mp}=262-264{ }^{\circ} \mathrm{C}$. LCMS: $R_{\mathrm{t}}=3.38 \mathrm{~min}, 99 \mathrm{~A} \%$ @ $254 \mathrm{~nm},[\mathrm{M}+\mathrm{H}]^{+}=299.1 .{ }^{1} \mathrm{H}$ NMR $\left(600 \mathrm{MHz}\right.$, DMSO- $\left.d_{6}\right): \delta 8.78(\mathrm{~s}, 1 \mathrm{H}), 7.52(\mathrm{~d}, J=5.8 \mathrm{~Hz}$, $1 \mathrm{H}), 7.26(\mathrm{~d}, J=5.9 \mathrm{~Hz}, 1 \mathrm{H}), 7.12(\mathrm{~d}, J=7.8 \mathrm{~Hz}, 2 \mathrm{H}), 7.09(\mathrm{~d}, J=$ $7.8 \mathrm{~Hz}, 2 \mathrm{H}), 4.10(\mathrm{dd}, J=8.4,6.7 \mathrm{~Hz}, 2 \mathrm{H}), 2.92(\mathrm{t}, J=7.5 \mathrm{~Hz}, 2 \mathrm{H})$, $2.25(\mathrm{~s}, 3 \mathrm{H}) .{ }^{13} \mathrm{C}$ NMR $\left(150 \mathrm{MHz}, \mathrm{DMSO}-d_{6}\right): \delta 152.6,148.0,135.5$, 135.0, 134.7, 129.1, 128.7, 123.7, 116.4, 106.7, 49.0, 33.7, 20.7. HRMS (ESI) $m / z$ : calcd for $\mathrm{C}_{15} \mathrm{H}_{15} \mathrm{~N}_{4} \mathrm{O}_{3}[\mathrm{M}+\mathrm{H}]^{+}, 299.1139$; found, 299.1132.

2-(2-Nitro-8-oxoimidazo[1,2-a]pyrazin-7(8H)-yl)ethyl Acetate; 17o. Imidazopyrazinone $17 \mathrm{a}(70 \mathrm{mg}, 0.39 \mathrm{mmol}), \mathrm{K}_{2} \mathrm{CO}_{3}$, and 2 bromoethylacetate (1.5 equiv) were reacted according to general procedure $\mathrm{A}\left(\mu \mathrm{W} 80^{\circ} \mathrm{C}, 30 \mathrm{~min}\right)$. The imidazopyrazinone:imidazopyrazine isomers were detected in a 10:1 ratio by LCMS (UV 254 $\mathrm{nm})$. The reaction was poured into $\mathrm{H}_{2} \mathrm{O}(20 \mathrm{~mL})$, and the precipitate is filtered to yield a cream solid $(72 \mathrm{mg}, 69 \%)$. LCMS: $R_{\mathrm{t}}=2.18 \mathrm{~min}$, $99 \mathrm{~A} \% @ 254 \mathrm{~nm},[\mathrm{M}+\mathrm{H}]^{+}=267.0 .{ }^{1} \mathrm{H}$ NMR $(600 \mathrm{MHz}, \mathrm{DMSO}-$ $\left.d_{6}\right): \delta 8.81(\mathrm{~s}, 1 \mathrm{H}), 7.58(\mathrm{~d}, J=5.9 \mathrm{~Hz}, 1 \mathrm{H}), 7.35(\mathrm{~d}, J=5.9 \mathrm{~Hz}, 1 \mathrm{H})$, $4.33-4.27(\mathrm{~m}, 2 \mathrm{H}), 4.19-4.14(\mathrm{~m}, 2 \mathrm{H}), 1.97(\mathrm{~s}, 3 \mathrm{H}) .{ }^{13} \mathrm{C}$ NMR $(150$ $\left.\mathrm{MHz}, \mathrm{DMSO}-d_{6}\right): \delta 170.2,152.8,147.9,134.9,124.0,116.5,106.8$, 61.3, 46.7, 20.6. HRMS (ESI) $m / z$ : calcd for $\mathrm{C}_{10} \mathrm{H}_{10} \mathrm{~N}_{4} \mathrm{NaO}_{5}[\mathrm{M}+$ $\mathrm{Na}]^{+}, 289.0543$; found, 289.0545 .

7-(2-Hydroxyethyl)-2-nitroimidazo[1,2-a]pyrazin-8(7H)-one; 17p. Compound $17 \mathrm{o}(45 \mathrm{mg}, 0.17 \mathrm{mmol})$ was reacted according to general procedure $\mathrm{D}$. The product was purified over $\mathrm{C} 18$ silica gel by MPLC (Grace Reveleris X2, A: $\mathrm{H}_{2} \mathrm{O}+0.1 \%$ TFA, B: ACN $+0.1 \%$ TFA, $5-22 \% \mathrm{~B})$ to yield a pale lemon powder $(18 \mathrm{mg}, 45 \%)$. LCMS: $R_{\mathrm{t}}=1.79 \mathrm{~min}, 99 \mathrm{~A} \% @ 254 \mathrm{~nm},[\mathrm{M}+\mathrm{H}]^{+}=225.0 .{ }^{1} \mathrm{H}$ NMR $(600$ $\left.\mathrm{MHz}, \mathrm{DMSO}-d_{6}\right): \delta 8.81(\mathrm{~s}, 1 \mathrm{H}), 7.55(\mathrm{~d}, J=5.9 \mathrm{~Hz}, 1 \mathrm{H}), 7.29(\mathrm{~d}, J$ $=5.8 \mathrm{~Hz}, 1 \mathrm{H}), 4.90(\mathrm{t}, J=5.7 \mathrm{~Hz}, 1 \mathrm{H}), 3.96(\mathrm{t}, J=5.5 \mathrm{~Hz}, 2 \mathrm{H}), 3.66$ $(\mathrm{q}, J=5.6 \mathrm{~Hz}, 2 \mathrm{H}) \cdot{ }^{13} \mathrm{C}$ NMR $\left(150 \mathrm{MHz}\right.$, DMSO- $\left.d_{6}\right): \delta 152.8,147.9$, 135.1, 124.7, 116.3, 106.2, 58.4, 50.3. HRMS (ESI) $\mathrm{m} / z$ : calcd for $\mathrm{C}_{8} \mathrm{H}_{8} \mathrm{~N}_{4} \mathrm{NaO}_{4}[\mathrm{M}+\mathrm{Na}]^{+}$, 247.0438; found, 247.0435.

4-(2-(2-Nitro-8-oxoimidazo[1,2-a]pyrazin-7(8H)-yl)ethyl)morpholin-4-ium 2,2,2-Trifluoroacetate; 17q. Imidazopyrazinone $17 \mathrm{a}(75 \mathrm{mg}, 0.42 \mathrm{mmol}), 4$-(2-chloroethyl)morpholine hydrochloride ( 1.5 equiv), potassium iodide ( 0.06 equiv), $\mathrm{K}_{2} \mathrm{CO}_{3}$ (3 equiv), and anh. DMF (20 vol) were reacted according to general procedure A $\left(\mu \mathrm{W} 120{ }^{\circ} \mathrm{C}, 15 \mathrm{~min}\right)$. To achieve conversion of the imidazopyrazinone starting material, further portions of potassium iodide (0.09 equiv), 4-(2-chloroethyl)morpholine hydrochloride (1.5 equiv) and anh. $\mathrm{K}_{2} \mathrm{CO}_{3}$ (1.5 equiv) were added and the reaction was heated in the microwave for a further $30 \mathrm{~min}$ at $120^{\circ} \mathrm{C}$ and then for $15 \mathrm{~min}$ at $150{ }^{\circ} \mathrm{C}$. The reaction was then evaporated to dryness to give crude material containing imidazopyrazinone (major) and imidazopyrazine (minor) isomers in a 13:1 ratio by LCMS (UV $254 \mathrm{~nm}$ ). The crude solid was purified over C18 silica gel by MPLC (Grace Reveleris X2, A: $\mathrm{H}_{2} \mathrm{O}+0.1 \%$ TFA, B: ACN $+0.1 \%$ TFA, $5-15 \%$ B) to yield imidazopyrazinone $17 \mathrm{q}$ as a sticky solid (143 $\mathrm{mg}, 84 \%)$ and imidazopyrazine $18 \mathrm{q}$ as a red residue $(6 \mathrm{mg}$, 5\%). Major isomer imidazopyrazinone 17q: LCMS: $R_{\mathrm{t}}=1.58 \mathrm{~min}, 99 \mathrm{~A} \%$ @ $254 \mathrm{~nm}$, $[\mathrm{M}+\mathrm{H}]^{+}=294.1 .{ }^{1} \mathrm{H}$ NMR $\left(600 \mathrm{MHz}, \mathrm{DMSO}-d_{6}\right): \delta 9.94(\mathrm{br} \mathrm{s}$, $1 \mathrm{H}), 8.86(\mathrm{~s}, 1 \mathrm{H}), 7.67(\mathrm{~d}, J=5.9 \mathrm{~Hz}, 1 \mathrm{H}), 7.37(\mathrm{~d}, J=5.9 \mathrm{~Hz}, 1 \mathrm{H})$, $4.31(\mathrm{t}, J=6.2 \mathrm{~Hz}, 2 \mathrm{H}), 4.12-3.89(\mathrm{~m}, 2 \mathrm{H}), 3.85-3.32(\mathrm{~m}, 4 \mathrm{H})$, 3.29-2.95 (m, 2H), 2.92-2.60 (m, 2H). ${ }^{13} \mathrm{C}$ NMR (150 MHz, DMSO- $\left.d_{6}\right): \delta 153.6,148.0,135.0,123.2,116.6,107.7,63.3,54.3$, 52.4, 51.5, 51.0, 41.4. HRMS (ESI) $\mathrm{m} / z$ : calcd for $\mathrm{C}_{12} \mathrm{H}_{16} \mathrm{~N}_{5} \mathrm{O}_{4}[\mathrm{M}+$ $\mathrm{H}]^{+}$, 294.1197; found, 294.1197. Characterization data of $\mathbf{1 8 q}$ are listed below following compounds $17 \mathbf{a}-\mathbf{t}$.

7-(2-Morpholino-2-oxoethyl)-2-nitroimidazo[1,2-a]pyrazin8 (7H)-one; $17 \mathrm{r}$. Imidazopyrazinone $17 \mathrm{a}(75 \mathrm{mg}, 0.42 \mathrm{mmol}), \mathrm{K}_{2} \mathrm{CO}_{3}$, and 4-(chloroacetyl)morpholine (1.2 equiv) were reacted according to general procedure A $(\mathrm{rt}, 2.5 \mathrm{~h})$. The reaction volatiles were removed in vacuo. The imidazopyrazinone isomer was detected in a 99:1 ratio by LCMS (UV $254 \mathrm{~nm}$ ). A solid precipitated from the ACN: $\left(\mathrm{H}_{2} \mathrm{O}+0.1 \%\right.$ TFA $)$ mixture and was filtered. The solid was then washed with water $(500 \mu \mathrm{L})$ and $\mathrm{ACN}(500 \mu \mathrm{L})$ and volatiles were removed in vacuo to yield a tan pearlescent solid ( $80 \mathrm{mg}, 63 \%)$. LCMS: $R_{\mathrm{t}}=2.44 \min , 99 \mathrm{~A} \% @ 254 \mathrm{~nm},[\mathrm{M}+\mathrm{H}]^{+}=308.1{ }^{1} \mathrm{H}$ 
NMR (600 MHz, DMSO- $\left.d_{6}\right): \delta 8.85(\mathrm{~s}, 1 \mathrm{H}), 7.59(\mathrm{~d}, J=5.9 \mathrm{~Hz}$, $1 \mathrm{H}), 7.24(\mathrm{~d}, J=5.9 \mathrm{~Hz}, 1 \mathrm{H}), 4.89(\mathrm{~s}, 2 \mathrm{H}), 3.66(\mathrm{t}, J=4.8 \mathrm{~Hz}, 2 \mathrm{H})$, $3.59(\mathrm{t}, J=4.9 \mathrm{~Hz}, 2 \mathrm{H}), 3.54(\mathrm{t}, J=4.9 \mathrm{~Hz}, 2 \mathrm{H}), 3.45(\mathrm{t}, J=4.9 \mathrm{~Hz}$, $2 \mathrm{H}), 3.33(\mathrm{~s}, 1 \mathrm{H}) .{ }^{13} \mathrm{C}$ NMR $\left(150 \mathrm{MHz}, \mathrm{DMSO}-d_{6}\right): \delta 164.8,152.8$, 148.0, 134.8, 124.7, 116.8, 106.6, 66.0, 65.9, 48.7, 44.6, 41.9. HRMS (ESI) $\mathrm{m} / z$ : calcd for $\mathrm{C}_{12} \mathrm{H}_{13} \mathrm{~N}_{5} \mathrm{NaO}_{5}[\mathrm{M}+\mathrm{Na}]^{+}$, 330.0809; found, 330.0819 .

2-(2-Nitro-8-oxoimidazo[1,2-a]pyrazin-7(8H)-yl)acetamide; $17 \mathrm{~s}$. Imidazopyrazinone $17 \mathrm{a}(75 \mathrm{mg}, 0.42 \mathrm{mmol}), \mathrm{K}_{2} \mathrm{CO}_{3}$, and 2bromoacetamide (1.2 equiv) were reacted according to general procedure $\mathrm{A}$ at $\mathrm{rt}$ for $1.5 \mathrm{~h}$. The imidazopyrazinone:imidazopyrazine isomers were detected in a 32:1 ratio by LCMS (UV $254 \mathrm{~nm}$ ). The reaction was then filtered, and the precipitate was washed with water $(4 \times 250 \mu \mathrm{L})$ and $\mathrm{MeOH}(2 \times 250 \mu \mathrm{L})$. The crude material was purified over $\mathrm{C} 18$ silica gel by MPLC (Grace Reveleris X2, A: $\mathrm{H}_{2} \mathrm{O}+$ $0.1 \%$ TFA, B: ACN $+0.1 \%$ TFA, $5-25 \%$ B) to yield a tan solid ( $5 \mathrm{mg}$, 4\%). LCMS: $R_{\mathrm{t}}=1.75 \mathrm{~min}, 99 \mathrm{~A} \% @ 254 \mathrm{~nm},[\mathrm{M}+\mathrm{H}]^{+}=238.0 .{ }^{1} \mathrm{H}$ NMR $\left(600 \mathrm{MHz}\right.$, DMSO- $\left.d_{6}\right): \delta 8.84(\mathrm{~s}, 1 \mathrm{H}), 7.66(\mathrm{br} \mathrm{s}, 1 \mathrm{H}), 7.57$ (d, $J=5.9 \mathrm{~Hz}, 1 \mathrm{H}), 7.31(\mathrm{br} \mathrm{s}, 1 \mathrm{H}), 7.30(\mathrm{~d}, J=5.8 \mathrm{~Hz}, 1 \mathrm{H}), 6.57(\mathrm{~s}$, $0.3 \mathrm{H}), 4.52(\mathrm{~s}, 2 \mathrm{H})$. A broad singlet that was exchangeable with water was observed at $6.57 \mathrm{ppm}$ integrating for $0.3 \mathrm{H}$. This has previously been observed for this class of compounds and is proposed to be due to protonation of the imidazopyrazinone core. ${ }^{13} \mathrm{C}$ NMR $(150 \mathrm{MHz}$, DMSO- $\left.d_{6}\right): \delta 168.2,152.9,148.0,135.1,124.8,116.6,106.6,49.9$. HRMS (ESI) $m / z$ : calcd for $\mathrm{C}_{8} \mathrm{H}_{7} \mathrm{~N}_{5} \mathrm{NaO}_{4}[\mathrm{M}+\mathrm{Na}]^{+}, 260.0390$; found, 260.0392 .

7-Cyclohexyl-2-nitroimidazo[1,2-a]pyrazin-8(7H)-one; $17 t$. Compound 19t (79 mg, $0.22 \mathrm{mmol}$ ) was reacted according to general procedure $\mathrm{C}$, work-up procedure $\mathrm{B}$. The crude material was purified by recrystallization (DCM/EtOH) to yield a cream-colored crystalline solid $(42 \mathrm{mg}, 68 \%) . \mathrm{mp}=275-277{ }^{\circ} \mathrm{C}$ (decomposed). LCMS: $R_{\mathrm{t}}=3.20 \mathrm{~min}, 99 \mathrm{~A} \%$ @ $254 \mathrm{~nm},[\mathrm{M}+\mathrm{H}]^{+}=263.1 .{ }^{1} \mathrm{H}$ NMR $\left(600 \mathrm{MHz}\right.$, DMSO- $\left.d_{6}\right): \delta 8.76(\mathrm{~s}, 1 \mathrm{H}), 7.58(\mathrm{~d}, J=6.0 \mathrm{~Hz}$, $1 \mathrm{H}), 7.43(\mathrm{~d}, J=6.1 \mathrm{~Hz}, 1 \mathrm{H}), 4.66(\mathrm{tt}, J=12.1,3.8 \mathrm{~Hz}, 1 \mathrm{H}), 1.83(\mathrm{~d}$, $J=13.6 \mathrm{~Hz}, 2 \mathrm{H}), 1.74(\mathrm{~d}, J=12.0 \mathrm{~Hz}, 2 \mathrm{H}), 1.64(\mathrm{qd}, J=12.3,3.6$ $\mathrm{Hz}, 3 \mathrm{H}), 1.41(\mathrm{qt}, J=12.5,3.4 \mathrm{~Hz}, 2 \mathrm{H}), 1.20(\mathrm{qt}, J=12.5,4.0 \mathrm{~Hz}$, $1 \mathrm{H}) .{ }^{13} \mathrm{C}$ NMR $\left(150 \mathrm{MHz}, \mathrm{DMSO}-d_{6}\right): \delta 152.3,148.0,135.0,119.8$, 116.2, 107.1, 53.3, 30.8, 25.3, 24.7. HRMS (ESI) $\mathrm{m} / z$ : calcd for $\mathrm{C}_{12} \mathrm{H}_{14} \mathrm{~N}_{4} \mathrm{NaO}_{3}[\mathrm{M}+\mathrm{Na}]^{+}$, 285.0958; found, 285.0953.

8-((3-Methylbenzyl)oxy)-2-nitroimidazo[1,2-a]pyrazine; $18 \mathrm{~g}$. Minor isomer imidazopyrazine $\mathbf{1 8} \mathrm{g}$ was isolated as described in the preparation of 17g. LCMS: $R_{\mathrm{t}}=3.58 \mathrm{~min}, 99 \mathrm{~A} \% @ 254 \mathrm{~nm},[\mathrm{M}+$ $\mathrm{H}]^{+}=285.1 ;{ }^{1} \mathrm{H}$ NMR $\left(600 \mathrm{MHz}, \mathrm{DMSO}-d_{6}\right): \delta 9.02(\mathrm{t}, J=1.8 \mathrm{~Hz}$, $1 \mathrm{H}), 8.25(\mathrm{dt}, J=3.8,1.7 \mathrm{~Hz}, 1 \mathrm{H}), 7.65(\mathrm{dt}, J=4.0,1.8 \mathrm{~Hz}, 1 \mathrm{H})$, $7.36-7.28(\mathrm{~m}, 3 \mathrm{H}), 7.20(\mathrm{dd}, J=6.8,3.5 \mathrm{~Hz}, 1 \mathrm{H}), 5.55-5.51(\mathrm{~m}$, $2 \mathrm{H}), 3.42(\mathrm{~s}, 1 \mathrm{H}), 2.34(\mathrm{~d}, J=2.1 \mathrm{~Hz}, 3 \mathrm{H})$. Impurities were detected by ${ }^{1} \mathrm{H}$ NMR and this compound was not subjected to biological evaluation.

2-Nitro-8-((3-(trifluoromethyl)benzyl)oxy)imidazo[1,2-a]pyrazine; $18 \mathrm{~h}$. Minor isomer imidazopyrazine $18 \mathrm{~h}$ was isolated as described in the preparation of 17h. LCMS: $R_{\mathrm{t}}=3.22 \mathrm{~min}, 99 \mathrm{~A} \%$ @ $254 \mathrm{~nm},[\mathrm{M}+\mathrm{H}]^{+}=339.1 ;{ }^{1} \mathrm{H} \mathrm{NMR}\left(600 \mathrm{MHz}, \mathrm{CDCl}_{3}\right): \delta 8.31(\mathrm{~s}$, $1 \mathrm{H}), 7.81-7.76(\mathrm{~m}, 2 \mathrm{H}), 7.76-7.72(\mathrm{~m}, 1 \mathrm{H}), 7.63-7.58(\mathrm{~m}, 2 \mathrm{H})$, $7.54-7.48(\mathrm{~m}, 1 \mathrm{H}), 5.67(\mathrm{~s}, 2 \mathrm{H})$. Impurities were detected by ${ }^{1} \mathrm{H}$ NMR, and this compound was not subjected to biological evaluation.

2-Nitro-8-((2-(trifluoromethoxy)benzyl)oxy)imidazo[1,2-a]pyrazine; 18i. Minor isomer imidazopyrazine $18 \mathbf{i}$ was isolated as described in the preparation of 17i. LCMS: $R_{\mathrm{t}}=3.25 \mathrm{~min}, 99 \mathrm{~A} \% @$ $254 \mathrm{~nm},[\mathrm{M}+\mathrm{H}]^{+}=355.1 ;{ }^{1} \mathrm{H}$ NMR $\left(600 \mathrm{MHz}, \mathrm{DMSO}-d_{6}\right): \delta 9.04$ $(\mathrm{s}, 1 \mathrm{H}), 8.27(\mathrm{~d}, J=4.7 \mathrm{~Hz}, 1 \mathrm{H}), 7.76-7.72(\mathrm{~m}, 1 \mathrm{H}), 7.66(\mathrm{~d}, J=4.7$ $\mathrm{Hz}, 1 \mathrm{H}), 7.60-7.53(\mathrm{~m}, 1 \mathrm{H}), 7.51-7.44(\mathrm{~m}, 2 \mathrm{H}), 5.64(\mathrm{~s}, 2 \mathrm{H}) ;{ }^{13} \mathrm{C}$ NMR $\left(150 \mathrm{MHz}\right.$, DMSO- $\left.d_{6}\right): \delta 153.8,148.2,146.7,131.2,130.6$, $130.1,128.3,128.0,127.7,120.7,120.2(\mathrm{q}, J=258.3 \mathrm{~Hz}), 116.5$, 115.0, 62.7. $\delta$ HRMS (ESI) $\mathrm{m} / z$ : calcd for $\mathrm{C}_{14} \mathrm{H}_{9} \mathrm{~F}_{3} \mathrm{~N}_{4} \mathrm{O}_{4} \mathrm{Na}[\mathrm{M}+$ $\mathrm{Na}]^{+}, 377.0468$; found, 377.0470.

2-Nitro-8-(4-(trifluoromethoxy)phenethoxy)imidazo[1,2-a]pyrazine; $18 \mathrm{~m}$. Minor isomer imidazopyrazine $18 \mathrm{~m}$ was isolated as described in the preparation of $17 \mathbf{m}$. LCMS: $R_{\mathrm{t}}=3.76 \mathrm{~min}, 99 \mathrm{~A} \% @$ $254 \mathrm{~nm},[\mathrm{M}+\mathrm{H}]^{+}=369.1 .{ }^{1} \mathrm{H}$ NMR $\left(600 \mathrm{MHz}, \mathrm{DMSO}-d_{6}\right): \delta 9.01$ $(\mathrm{s}, 1 \mathrm{H}), 8.22(\mathrm{~d}, J=4.7 \mathrm{~Hz}, 1 \mathrm{H}), 7.62(\mathrm{~d}, J=4.7 \mathrm{~Hz}, 1 \mathrm{H}), 7.52-7.46$ $(\mathrm{m}, 2 \mathrm{H}), 7.34-7.29(\mathrm{~m}, 2 \mathrm{H}), 4.73(\mathrm{t}, J=6.7 \mathrm{~Hz}, 2 \mathrm{H}), 3.20(\mathrm{t}, J=6.7$ $\mathrm{Hz}, 2 \mathrm{H}) .{ }^{13} \mathrm{C}$ NMR $\left(150 \mathrm{MHz}\right.$, DMSO- $\left.d_{6}\right): \delta 154.3,148.2,147.0$, $137.7,130.8,128.2,121.1,120.1(\mathrm{q}, J=256.2 \mathrm{~Hz}), 116.0,114.9,67.1$, 33.5. HRMS (ESI) $m / z$ : calcd for $\mathrm{C}_{15} \mathrm{H}_{12} \mathrm{~F}_{3} \mathrm{~N}_{4} \mathrm{O}_{4}[\mathrm{M}+\mathrm{H}]^{+}$, 369.0805; found, 369.0799 .

4-(2-((2-Nitroimidazo[1,2-a]pyrazin-8-yl)oxy)ethyl)morpholin-4ium 2,2,2-Trifluoroacetate; $18 \mathbf{q}$. Minor isomer imidazopyrazine $\mathbf{1 8 q}$ was isolated as described in the preparation of 17q. LCMS: $R_{\mathrm{t}}=2.31$ min, 97 A \% @254 nm, $[\mathrm{M}+\mathrm{H}]^{+}=294.1 .{ }^{1} \mathrm{H}$ NMR $(600 \mathrm{MHz}$, DMSO- $\left.d_{6}\right): \delta 9.08(\mathrm{~s}, 1 \mathrm{H}), 8.31(\mathrm{~d}, J=4.7 \mathrm{~Hz}, 1 \mathrm{H}), 7.67(\mathrm{~d}, J=4.7$ $\mathrm{Hz}, 1 \mathrm{H}), 4.85$ (br s, $2 \mathrm{H}), 4.27-3.02(\mathrm{~m}, 10 \mathrm{H})$. Impurities were detected in the ${ }^{1} \mathrm{H}$ NMR analysis, and therefore, the compound was not subjected to biological analysis.

1-(2,2-Diethoxyethyl)-4-nitro-1H-imidazole-2-carboxamide; 19a. Imidazole-2-carboxamide $16 \mathrm{a}(650 \mathrm{mg}, 3.38 \mathrm{mmol})$ was reacted according to general procedure $\mathrm{A}$ with $\mathrm{K}_{2} \mathrm{CO}_{3}$, bromoacetaldehyde diethyl acetal $(2 \times 1.5$ equiv $)$ at $\mu \mathrm{W} 180{ }^{\circ} \mathrm{C}(2 \times 15 \mathrm{~min})$. The crude material was triturated with pet. spirits $(3 \times 3 \mathrm{~mL})$ and dried in vacuo to yield an orange solid $(710 \mathrm{mg}, 77 \%)$. LCMS: $R_{\mathrm{t}}=3.04 \mathrm{~min}, 88 \mathrm{~A} \%$ (@ $254 \mathrm{~nm},[\mathrm{M}+\mathrm{H}-\mathrm{EtOH}]^{+}=227.0 .{ }^{1} \mathrm{H} \mathrm{NMR}(400 \mathrm{MHz}$, $\left.\mathrm{CDCl}_{3}\right): \delta 7.93(\mathrm{~s}, 1 \mathrm{H}), 7.93($ br s, $1 \mathrm{H}), 5.62(\mathrm{br} \mathrm{s}, 1 \mathrm{H}), 4.73(\mathrm{dd}, J=$ $5.2,4.5 \mathrm{~Hz}, 1 \mathrm{H}), 4.64(\mathrm{~d}, J=5.0 \mathrm{~Hz}, 2 \mathrm{H}), 3.75(\mathrm{dq}, J=9.4,7.1 \mathrm{~Hz}$ $2 \mathrm{H}), 3.53(\mathrm{dq}, J=9.4,7.0 \mathrm{~Hz}, 2 \mathrm{H}), 1.19(\mathrm{t}, J=7.0 \mathrm{~Hz}, 6 \mathrm{H}) .{ }^{13} \mathrm{C}$ NMR $\left(150 \mathrm{MHz}, \mathrm{CDCl}_{3}\right): \delta 159.5,145.3,136.2,125.4,100.5,64.2$, 51.8, 15.2. HRMS (ESI) $m / z$ : calcd for $\mathrm{C}_{10} \mathrm{H}_{16} \mathrm{~N}_{4} \mathrm{NaO}_{5}[\mathrm{M}+\mathrm{Na}]^{+}$, 295.1013; found, 295.1010 .

N-Benzyl-1-(2,2-diethoxyethyl)-4-nitro-1H-imidazole-2-carboxamide; 19b. Imidazole-2-carboxamide $16 \mathrm{~b}(150 \mathrm{mg}, 0.609 \mathrm{mmol})$ was reacted according to general procedure $A$ with $\mathrm{K}_{2} \mathrm{CO}_{3}$ and bromoacetaldehyde diethyl acetal (1.5 equiv, second portion $=0.5$ equiv) at $\mu \mathrm{W} 150{ }^{\circ} \mathrm{C}(30 \mathrm{~min}$, followed by $15 \mathrm{~min})$ to yield a waxy yellow solid (219 mg, 99\%). LCMS: $R_{\mathrm{t}}=3.72 \mathrm{~min}, 97 \mathrm{~A} \%$ @ 254 $\mathrm{nm},[\mathrm{M}+\mathrm{H}-\mathrm{EtOH}]^{+}=317.1 .{ }^{1} \mathrm{H}$ NMR $\left(400 \mathrm{MHz}, \mathrm{CDCl}_{3}\right): \delta 7.91$ $(\mathrm{s}, 1 \mathrm{H}), 7.68(\mathrm{t}, J=4.5 \mathrm{~Hz}, 1 \mathrm{H}), 7.40-7.27(\mathrm{~m}, 5 \mathrm{H}), 4.75(\mathrm{dd}, J=$ $5.3,4.5 \mathrm{~Hz}, 1 \mathrm{H}), 4.68(\mathrm{~d}, J=4.8 \mathrm{~Hz}, 2 \mathrm{H}), 4.57(\mathrm{~d}, J=6.1 \mathrm{~Hz}, 2 \mathrm{H})$, $3.75(\mathrm{dq}, J=9.0,7.3 \mathrm{~Hz}, 2 \mathrm{H}), 3.54(\mathrm{dq}, J=9.4,6.9 \mathrm{~Hz}, 2 \mathrm{H}), 1.19(\mathrm{t}, J$ $=7.1 \mathrm{~Hz}, 6 \mathrm{H}) \cdot{ }^{13} \mathrm{C} \mathrm{NMR}\left(150 \mathrm{MHz}, \mathrm{CDCl}_{3}\right): \delta 157.5,145.2,136.9$, 136.8, 128.8, 128.0, 127.9, 125.2, 100.6, 64.2, 51.6, 43.4, 15.2. HRMS (ESI) $m / z$ : calcd for $\mathrm{C}_{17} \mathrm{H}_{22} \mathrm{~N}_{4} \mathrm{NaO}_{5}[\mathrm{M}+\mathrm{Na}]^{+}, 385.1482$; found, 385.1480

1-(2,2-Diethoxyethyl)-4-nitro-N-(4-(trifluoromethoxy)benzyl)$1 \mathrm{H}$-imidazole-2-carboxamide; 19c. Imidazole-2-carboxamide $16 \mathrm{c}$ (125 mg, $0.332 \mathrm{mmol}$ ) was reacted according to general procedure A with $\mathrm{K}_{2} \mathrm{CO}_{3}$ and bromoacetaldehyde diethyl acetal $(2 \times 1.5$ equiv $)$ at $\mu \mathrm{W} 180{ }^{\circ} \mathrm{C}(2 \times 15 \mathrm{~min})$. The crude residue was purified over silica gel by MPLC (Biotage, $12-100 \%$ EtOAc in pet. spirits gradient) to yield a pale yellow waxy solid $(112 \mathrm{mg}, 76 \%)$. LCMS: $R_{\mathrm{t}}=3.40 \mathrm{~min}$, $99 \mathrm{~A} \%$ @ $254 \mathrm{~nm},[\mathrm{M}-\mathrm{H}]^{-}=445.0 .{ }^{1} \mathrm{H} \mathrm{NMR}\left(600 \mathrm{MHz}, \mathrm{CDCl}_{3}\right)$ : $\delta 7.92(\mathrm{~s}, 1 \mathrm{H}), 7.75($ br t, $1 \mathrm{H}), 7.39-7.33(\mathrm{~m}, 2 \mathrm{H}), 7.20(\mathrm{~m}, 2 \mathrm{H})$, $4.74(\mathrm{dd}, J=5.1,4.5 \mathrm{~Hz}, 1 \mathrm{H}), 4.67(\mathrm{~d}, J=4.8 \mathrm{~Hz}, 2 \mathrm{H}), 4.57(\mathrm{~d}, J=$ $6.2 \mathrm{~Hz}, 2 \mathrm{H}), 3.75(\mathrm{dq}, J=9.4,7.0 \mathrm{~Hz}, 2 \mathrm{H}), 3.53(\mathrm{dq}, J=9.4,7.0 \mathrm{~Hz}$, $2 \mathrm{H}), 1.18(\mathrm{t}, J=7.0 \mathrm{~Hz}, 6 \mathrm{H}) .{ }^{13} \mathrm{C} \mathrm{NMR}\left(150 \mathrm{MHz}, \mathrm{CDCl}_{3}\right): \delta 157.8$, $148.9,145.4,136.8,136.0,129.5,125.4,121.5,120.6$ (q) $J=256.5$ $\mathrm{Hz}$ ), 100.7, 64.3, 51.7, 42.7, 15.3. HRMS (ESI) $\mathrm{m} / \mathrm{z}$ : calcd for $\mathrm{C}_{18} \mathrm{H}_{21} \mathrm{~F}_{3} \mathrm{~N}_{4} \mathrm{NaO}_{6}[\mathrm{M}+\mathrm{Na}]^{+}$, 469.1305; found, 469.1316 .

1-(2,2-Diethoxyethyl)-N-(4-methylbenzyl)-4-nitro-1H-imidazole2-carboxamide; 19d. Imidazole-2-carboxamide $16 \mathrm{~d}(75 \mathrm{mg}, 0.29$ mmol) was reacted according to general procedure $\mathrm{A}$ with $\mathrm{K}_{2} \mathrm{CO}_{3}$ and bromoacetaldehyde diethyl acetal $(2 \times 1.5$ equiv $)$ at $\mu \mathrm{W} 150{ }^{\circ} \mathrm{C}(2 \times$ $30 \mathrm{~min})$ to yield a yellow oil which was used without further purification (116 mg with $43 \mathrm{~mol} \%$ residual DMF by ${ }^{1} \mathrm{H}$ NMR, 98\%). LCMS: $R_{\mathrm{t}}=3.80 \mathrm{~min}, 97 \mathrm{~A} \% @ 254 \mathrm{~nm},[\mathrm{M}+\mathrm{H}-\mathrm{EtOH}]^{+}=$ 331.1. ${ }^{1} \mathrm{H}$ NMR $\left(600 \mathrm{MHz}, \mathrm{CDCl}_{3}\right): \delta 7.92(\mathrm{~s}, 1 \mathrm{H}), 7.67(\mathrm{~d}, J=5.7$ $\mathrm{Hz}, 1 \mathrm{H}), 7.25-7.19(\mathrm{~m}, 2 \mathrm{H}), 7.19-7.14(\mathrm{~m}, 2 \mathrm{H}), 4.76(\mathrm{t}, J=4.9 \mathrm{~Hz}$, $1 \mathrm{H}), 4.68(\mathrm{~d}, J=4.9 \mathrm{~Hz}, 2 \mathrm{H}), 4.54(\mathrm{~d}, J=6.1 \mathrm{~Hz}, 2 \mathrm{H}), 3.77(\mathrm{dq}, J=$ 9.4, 7.0 Hz, 2H), $3.55(\mathrm{dq}, J=9.4,7.0 \mathrm{~Hz}, 2 \mathrm{H}), 2.35(\mathrm{~s}, 3 \mathrm{H}), 1.19(\mathrm{t}$, $J=7.0 \mathrm{~Hz}, 5 \mathrm{H}) .{ }^{13} \mathrm{C} \mathrm{NMR}\left(151 \mathrm{MHz}, \mathrm{CDCl}_{3}\right): \delta 157.5,145.2,137.6$, $136.9,133.9,129.5,128.0,125.2,100.6,64.2,51.6,43.2,21.1,15.2$. HRMS (ESI) $m / z$ : calcd for $\mathrm{C}_{18} \mathrm{H}_{24} \mathrm{~N}_{4} \mathrm{NaO}_{5}[\mathrm{M}+\mathrm{Na}]^{+}, 399.1639$; found, 399.1643 . 
1-(2,2-Diethoxyethyl)-N-(4-fluorobenzyl)-4-nitro-1H-imidazole2-carboxamide; 19e. Imidazole-2-carboxamide $16 \mathrm{e}(311 \mathrm{mg}, 1.18$ mmol) was reacted according to general procedure $\mathrm{A}$ with $\mathrm{K}_{2} \mathrm{CO}_{3}$ and bromoacetaldehyde diethyl acetal $(2 \times 1.5$ equiv $)$ at $\mu \mathrm{W} 180^{\circ} \mathrm{C}(2 \times$ $15 \mathrm{~min})$. The crude residue was purified over silica gel by MPLC (Biotage, $10-60 \%$ EtOAc in pet. spirits gradient) to yield a pale yellow oil (411 mg, 92\%). LCMS: $R_{\mathrm{t}}=3.76 \mathrm{~min}, 99 \mathrm{~A} \%$ @ $254 \mathrm{~nm}$, $[\mathrm{M}+\mathrm{H}-\mathrm{EtOH}]^{+}=335.0 .{ }^{1} \mathrm{H}$ NMR $\left(400 \mathrm{MHz}, \mathrm{CDCl}_{3}\right): \delta 7.91(\mathrm{~s}$, $1 \mathrm{H}), 7.70(\mathrm{br} \mathrm{s}, 1 \mathrm{H}), 7.35-7.27(\mathrm{~m}, 2 \mathrm{H}), 7.09-6.98(\mathrm{~m}, 2 \mathrm{H}), 4.74$ $(\mathrm{dd}, J=5.2,4.4 \mathrm{~Hz}, 1 \mathrm{H}), 4.67(\mathrm{~d}, J=4.8 \mathrm{~Hz}, 2 \mathrm{H}), 4.60-4.50(\mathrm{~m}$, $2 \mathrm{H}), 3.75(\mathrm{dq}, J=9.4,7.0 \mathrm{~Hz}, 2 \mathrm{H}), 3.54(\mathrm{dq}, J=9.4,7.0 \mathrm{~Hz}, 2 \mathrm{H})$, $1.18(\mathrm{t}, J=7.0 \mathrm{~Hz}, 6 \mathrm{H}) .{ }^{13} \mathrm{C} \mathrm{NMR}\left(150 \mathrm{MHz}, \mathrm{CDCl}_{3}\right): \delta 162.4(\mathrm{~d}, J$ $=245.19 \mathrm{~Hz}), 157.6,145.3,136.8,132.8(\mathrm{~d}, J=3.8 \mathrm{~Hz}), 129.7(\mathrm{~d}, J=$ $8.1 \mathrm{~Hz}), 125.2,115.7(\mathrm{~d}, J=21.6 \mathrm{~Hz}), 100.6,64.2,51.6,42.7,15.2$. HRMS (ESI) $m / z$ : calcd for $\mathrm{C}_{17} \mathrm{H}_{21} \mathrm{~F}_{1} \mathrm{~N}_{4} \mathrm{NaO}_{5}[\mathrm{M}+\mathrm{Na}]^{+}, 403.1388$; found, 403.1389 .

1-(2,2-Diethoxyethyl)-4-nitro-N-(3-(trifluoromethoxy)benzyl)$1 \mathrm{H}$-imidazole-2-carboxamide; 19f. Imidazole-2-carboxamide $\mathbf{1 6 f}$ (75 $\mathrm{mg}, 0.23 \mathrm{mmol}$ ) was reacted according to general procedure A with $\mathrm{K}_{2} \mathrm{CO}_{3}$ and bromoacetaldehyde diethyl acetal $(2 \times 1.5$ equiv $)$ at $\mu \mathrm{W} 150{ }^{\circ} \mathrm{C}(2 \times 30 \mathrm{~min})$ to yield an orange solid which was used without further purification (108 mg, quant.). LCMS: $R_{\mathrm{t}}=3.88 \mathrm{~min}$, $95 \mathrm{~A} \% @ 254 \mathrm{~nm},[\mathrm{M}+\mathrm{H}-\mathrm{EtOH}]^{+}=401.1 .{ }^{1} \mathrm{H} \mathrm{NMR}(600 \mathrm{MHz}$, $\left.\mathrm{CDCl}_{3}\right): \delta 7.94(\mathrm{~s}, 1 \mathrm{H}), 7.81(\mathrm{t}, J=6.1 \mathrm{~Hz}, 1 \mathrm{H}), 7.39(\mathrm{t}, J=7.9 \mathrm{~Hz}$, $1 \mathrm{H}), 7.30-7.24(\mathrm{~m}, 1 \mathrm{H}), 7.21-7.14(\mathrm{~m}, 2 \mathrm{H}), 4.75(\mathrm{dd}, J=5.2,4.5$ $\mathrm{Hz}, 1 \mathrm{H}), 4.69(\mathrm{~d}, J=4.8 \mathrm{~Hz}, 2 \mathrm{H}), 4.60(\mathrm{~d}, J=6.3 \mathrm{~Hz}, 2 \mathrm{H}), 3.76(\mathrm{dq}$, $J=9.4,7.1 \mathrm{~Hz}, 2 \mathrm{H}), 3.54(\mathrm{dq}, J=9.4,7.0 \mathrm{~Hz}, 2 \mathrm{H}), 1.19(\mathrm{t}, J=7.0 \mathrm{~Hz}$, $6 \mathrm{H}) .{ }^{13} \mathrm{C}$ NMR $\left(150 \mathrm{MHz}, \mathrm{CDCl}_{3}\right): \delta 157.7,149.5,145.2,139.5$, $136.6,130.2,126.1,125.3,120.4(\mathrm{q}, J=260.9 \mathrm{~Hz}), 120.4,120.2$, $100.5,64.2,51.6,42.7$, 15.1. HRMS (ESI) $\mathrm{m} / z$ : calcd for $\mathrm{C}_{18} \mathrm{H}_{21} \mathrm{~F}_{3} \mathrm{~N}_{4} \mathrm{NaO}_{6}[\mathrm{M}+\mathrm{Na}]^{+}$, 469.1305; found, 469.1306.

1-(2,2-Diethoxyethyl)-4-nitro- $\mathrm{N}$-(pyridin-2-ylmethyl)- $1 \mathrm{H}$-imidazole-2-carboxamide; 19k. Imidazole-2-carboxamide $16 \mathrm{k}(150 \mathrm{mg}$, $0.607 \mathrm{mmol}$ ) was reacted according to general procedure A with $\mathrm{K}_{2} \mathrm{CO}_{3}$ and bromoacetaldehyde diethyl acetal (1.5 equiv, second portion $=0.5$ equiv $)$ at $\mu \mathrm{W} 150{ }^{\circ} \mathrm{C}(30 \mathrm{~min}$, followed by $15 \mathrm{~min})$ to yield a red oil which was used without further purification $(153 \mathrm{mg}$, 69\%). LCMS: $R_{\mathrm{t}}=3.13 \mathrm{~min}, 97 \mathrm{~A} \% @ 254 \mathrm{~nm},[\mathrm{M}+\mathrm{H}-\mathrm{EtOH}]^{+}=$ 318.1. ${ }^{1} \mathrm{H}$ NMR $\left(600 \mathrm{MHz}, \mathrm{DMSO}-d_{6}\right): \delta 9.41(\mathrm{t}, J=6.1 \mathrm{~Hz}, 1 \mathrm{H})$, $8.52(\mathrm{~s}, 1 \mathrm{H}), 8.51(\mathrm{ddd}, J=4.7,1.7,1.0 \mathrm{~Hz}, 1 \mathrm{H}), 7.76(\mathrm{td}, J=7.7,1.8$ $\mathrm{Hz}, 1 \mathrm{H}), 7.32(\mathrm{~d}, J=8.3 \mathrm{~Hz}, 1 \mathrm{H}), 7.27(\mathrm{ddd}, J=7.6,4.9,1.1 \mathrm{~Hz}$, $1 \mathrm{H}), 4.79(\mathrm{t}, J=5.2 \mathrm{~Hz}, 1 \mathrm{H}), 4.60(\mathrm{~d}, J=5.2 \mathrm{~Hz}, 2 \mathrm{H}), 4.53(\mathrm{~d}, J=6.1$ $\mathrm{Hz}, 2 \mathrm{H}), 3.61(\mathrm{dq}, J=9.7,7.0 \mathrm{~Hz}, 2 \mathrm{H}), 3.41(\mathrm{dq}, J=9.7,7.0 \mathrm{~Hz}$, $2 \mathrm{H}), 1.02(\mathrm{t}, J=7.0 \mathrm{~Hz}, 6 \mathrm{H}) .{ }^{13} \mathrm{C}$ NMR $\left(150 \mathrm{MHz}\right.$, DMSO- $\left.d_{6}\right): \delta$ $157.9,157.7,148.9,144.4,137.7,136.7,126.4,122.2,120.9,100.0$, $62.8,50.3,44.1,15.1$. HRMS (ESI) $m / z$ : calcd for $\mathrm{C}_{16} \mathrm{H}_{22} \mathrm{~N}_{5} \mathrm{O}_{5}[\mathrm{M}+$ $\mathrm{H}]^{+}, 364.1615$; found, 364.1622.

1-(2,2-Diethoxyethyl)-N-(1-(4-fluorophenyl)ethyl)-4-nitro-1 Himidazole-2-carboxamide; 19l. Imidazole-2-carboxamide 161 (75 $\mathrm{mg}, 0.27 \mathrm{mmol}$ ) was reacted according to general procedure A with $\mathrm{K}_{2} \mathrm{CO}_{3}$ and bromoacetaldehyde diethyl acetal (1.5 equiv, second portion $=1$ equiv $)$ at $\mu \mathrm{W} 150{ }^{\circ} \mathrm{C}(2 \times 30 \mathrm{~min})$ to yield a yellow oil (113 mg, quant) which was used without further purification. LCMS: $R_{\mathrm{t}}=3.80 \mathrm{~min}, 97 \mathrm{~A} \% @ 254 \mathrm{~nm},[\mathrm{M}+\mathrm{H}-\mathrm{EtOH}]^{+}=349.1 .{ }^{1} \mathrm{H}$ $\operatorname{NMR}\left(600 \mathrm{MHz}, \mathrm{CDCl}_{3}\right): \delta 7.92(\mathrm{~s}, 1 \mathrm{H}), 7.60(\mathrm{~d}, J=8.2 \mathrm{~Hz}, 1 \mathrm{H})$, $7.37-7.31(\mathrm{~m}, 2 \mathrm{H}), 7.08-7.01(\mathrm{~m}, 2 \mathrm{H}), 5.20(\mathrm{p}, J=7.2 \mathrm{~Hz}, 1 \mathrm{H})$, 4.74-4.66 (m, 2H), 4.65-4.56 (m, $1 \mathrm{H}), 3.77-3.69(\mathrm{~m}, 2 \mathrm{H}), 3.52$ $(\mathrm{dq}, J=9.4,7.0 \mathrm{~Hz}, 2 \mathrm{H}), 1.60(\mathrm{~d}, J=7.0 \mathrm{~Hz}, 3 \mathrm{H}), 1.17(\mathrm{dt}, J=12.1$, $7.0 \mathrm{~Hz}, 6 \mathrm{H}) \cdot{ }^{13} \mathrm{C}$ NMR $\left(150 \mathrm{MHz}, \mathrm{CDCl}_{3}\right): \delta 162.1(\mathrm{~d}, J=245.3$ $\mathrm{Hz}), 156.8,145.2,138.1(\mathrm{~d}, J=3.0 \mathrm{~Hz}), 136.8,127.8(\mathrm{~d}, J=8.2 \mathrm{~Hz})$, $125.3,115.6(\mathrm{~d}, J=21.8 \mathrm{~Hz}), 100.5,64.1,51.6,48.5,21.9,15.1$. HRMS (ESI) $m / z$ : calcd for $\mathrm{C}_{18} \mathrm{H}_{23} \mathrm{FN}_{4} \mathrm{NaO}_{5}[\mathrm{M}+\mathrm{Na}]^{+}, 417.1545$; found, 417.1537 .

1-(2,2-Diethoxyethyl)-N-(4-methylphenethyl)-4-nitro-1H-imidazole-2-carboxamide; $19 \mathrm{n}$. Imidazole-2-carboxamide $16 \mathrm{n}(75 \mathrm{mg}$, $0.27 \mathrm{mmol}$ ) was reacted according to general procedure A with $\mathrm{K}_{2} \mathrm{CO}_{3}$ and bromoacetaldehyde diethyl acetal $(2 \times 1.5$ equiv $)$ at $\mu \mathrm{W}$ $150{ }^{\circ} \mathrm{C}(2 \times 30 \mathrm{~min})$ to yield a yellow oil which was used without further purification (112 mg, quant.). LCMS: $R_{\mathrm{t}}=3.85 \mathrm{~min}, 98 \mathrm{~A} \%$ (a) $254 \mathrm{~nm},[\mathrm{M}+\mathrm{H}-\mathrm{EtOH}]^{+}=345.1 .{ }^{1} \mathrm{H}$ NMR $(600 \mathrm{MHz}$,
$\left.\mathrm{CDCl}_{3}\right): \delta 7.90(\mathrm{~s}, 1 \mathrm{H}), 7.46(\mathrm{t}, J=6.2 \mathrm{~Hz}, 1 \mathrm{H}), 7.19-7.03(\mathrm{~m}, 4 \mathrm{H})$, $4.72(\mathrm{t}, J=4.9 \mathrm{~Hz}, 1 \mathrm{H}), 4.64(\mathrm{~d}, J=4.9 \mathrm{~Hz}, 2 \mathrm{H}), 3.76(\mathrm{dq}, J=9.4$, $7.0 \mathrm{~Hz}, 2 \mathrm{H}), 3.64(\mathrm{dt}, J=7.7,6.5 \mathrm{~Hz}, 2 \mathrm{H}), 3.53(\mathrm{dq}, J=9.4,7.0 \mathrm{~Hz}$, $2 \mathrm{H}), 2.91-2.85(\mathrm{~m}, 2 \mathrm{H}), 2.34(\mathrm{~s}, 3 \mathrm{H}), 1.19(\mathrm{t}, J=7.0 \mathrm{~Hz}, 6 \mathrm{H}) .{ }^{13} \mathrm{C}$ NMR $\left(150 \mathrm{MHz}, \mathrm{CDCl}_{3}\right): \delta 157.6,145.1,136.9,136.2,135.1,129.4$, 128.6, 125.1, 100.7, 64.2, 51.6, 40.8, 35.3, 21.0, 15.2. HRMS (ESI) $\mathrm{m} /$ $z$ : calcd for $\mathrm{C}_{19} \mathrm{H}_{26} \mathrm{~N}_{4} \mathrm{NaO}_{5}[\mathrm{M}+\mathrm{Na}]^{+}$, 413.1795; found, 413.1797.

$\mathrm{N}$-Cyclohexyl-1-(2,2-diethoxyethyl)-4-nitro-1H-imidazole-2-carboxamide; $19 t$. Imidazole-2-carboxamide $16 \mathrm{t}(75 \mathrm{mg}, 0.31 \mathrm{mmol})$ was reacted according to general procedure $\mathrm{A}$ with $\mathrm{K}_{2} \mathrm{CO}_{3}$ and bromoacetaldehyde diethyl acetal (1.5 equiv, second portion $=1$ equiv) at $\mu \mathrm{W} 150{ }^{\circ} \mathrm{C}(2 \times 30 \mathrm{~min})$ to yield an orange solid $(107 \mathrm{mg}$, $96 \%)$ which was used without further purification. LCMS: $R_{\mathrm{t}}=3.78$ $\min , 97 \mathrm{~A} \% @ 254 \mathrm{~nm},[\mathrm{M}+\mathrm{H}]^{+}=309.1{ }^{1} \mathrm{H} \operatorname{NMR}(600 \mathrm{MHz}$, $\left.\mathrm{CDCl}_{3}\right): \delta 7.90(\mathrm{~s}, 1 \mathrm{H}), 7.24(\mathrm{~d}, J=8.5 \mathrm{~Hz}, 1 \mathrm{H}), 4.75(\mathrm{t}, J=5.0 \mathrm{~Hz}$, $1 \mathrm{H}), 4.65(\mathrm{~d}, J=5.0 \mathrm{~Hz}, 2 \mathrm{H}), 3.88(\mathrm{tdt}, J=11.9,8.2,3.9 \mathrm{~Hz}, 1 \mathrm{H})$, $3.76(\mathrm{dq}, J=9.3,7.1 \mathrm{~Hz}, 2 \mathrm{H}), 3.54(\mathrm{dq}, J=9.3,7.0 \mathrm{~Hz}, 2 \mathrm{H}), 2.02-$ $1.96(\mathrm{~m}, 2 \mathrm{H}), 1.83-1.77(\mathrm{~m}, 2 \mathrm{H}), 1.72-1.62(\mathrm{~m}, 1 \mathrm{H}), 1.44-1.35$ $(\mathrm{m}, 2 \mathrm{H}), 1.35-1.25(\mathrm{~m}, 3 \mathrm{H}), 1.19(\mathrm{t}, J=7.0 \mathrm{~Hz}, 6 \mathrm{H}) .{ }^{13} \mathrm{C}$ NMR $\left(150 \mathrm{MHz}, \mathrm{CDCl}_{3}\right): \delta 156.8,145.1,137.2,125.1,100.7,64.2,51.7$, $48.8,32.9,25.3,25.0$, 15.2. HRMS (ESI) $\mathrm{m} / \mathrm{z}$ : calcd for $\mathrm{C}_{16} \mathrm{H}_{26} \mathrm{~N}_{4} \mathrm{NaO}_{5}[\mathrm{M}+\mathrm{Na}]^{+}$, 377.1795; found, 377.1794.

Imidazo[1,2-a]pyrazin-8(7H)-one; 20a. To a stirred suspension of imidazole 23a ( $168 \mathrm{mg}, 0.741 \mathrm{mmol})$ in $\mathrm{H}_{2} \mathrm{O}(20 \mathrm{vol})$ was added $5 \%$ $\mathrm{w} / \mathrm{v} \mathrm{HCl}(530 \mu \mathrm{L}, 1$ equiv). The solution was heated at reflux for $2 \mathrm{~h}$, cooled to rt, and concentrated in vacuo to dryness. The solid was purified by recrystallization (slurry equilibration with hot $\mathrm{MeOH}$ ) to yield beige crystals $(50 \mathrm{mg}, 50 \%) . \mathrm{mp}=307-308^{\circ} \mathrm{C}$ (decomposed). LCMS (Waters Atlantis): $R_{\mathrm{t}}=1.75 \mathrm{~min}, 99 \mathrm{~A} \% @ 254 \mathrm{~nm},[\mathrm{M}+\mathrm{H}]^{+}$ $=136.1{ }^{1} \mathrm{H}$ NMR $\left(400 \mathrm{MHz}, \mathrm{DMSO}-d_{6}\right): \delta 8.20(\mathrm{~d}, J=1.7 \mathrm{~Hz}, 1 \mathrm{H})$, $8.01(\mathrm{~d}, J=1.7 \mathrm{~Hz}, 1 \mathrm{H}), 7.75(\mathrm{~d}, J=5.6 \mathrm{~Hz}, 1 \mathrm{H}), 7.23(\mathrm{t}, J=5.6 \mathrm{~Hz}$, $1 \mathrm{H}) .{ }^{13} \mathrm{C}$ NMR $\left(150 \mathrm{MHz}\right.$, DMSO- $\left.d_{6}\right): \delta 151.3,135.1,126.3,119.7$, 118.3, 107.2. HRMS calcd for $\mathrm{C}_{12} \mathrm{H}_{10} \mathrm{~N}_{6} \mathrm{NaO}_{2}[2 \mathrm{M}+\mathrm{Na}]^{+}$, 293.0757; found, 293.0764. The proton spectrum was consistent with the literature. $^{35}$

7-Benzylimidazo[1,2-a]pyrazin-8(7H)-one; 20b. To a stirred suspension of compound $23 \mathbf{b}(120 \mathrm{mg}, 0.378 \mathrm{mmol})$ in $\mathrm{H}_{2} \mathrm{O}(20$ vol.) was added $5 \%$ aq $\mathrm{HCl}(270 \mu \mathrm{L}, 1$ equiv). The reaction was heated at $80{ }^{\circ} \mathrm{C}$ for 3 days before further addition of $5 \%$ aq $\mathrm{HCl}(135$ $\mu \mathrm{L}, 0.5$ equiv). The reaction mixture was then washed with EtOAc ( 3 $\times 5 \mathrm{~mL}$ followed by $3 \times 10 \mathrm{~mL}$ ). The aqueous layer was then evaporated to dryness. The crude material was purified over $\mathrm{C} 18$ silica gel by MPLC (Grace Reveleris X2. A: $\mathrm{H}_{2} \mathrm{O}+0.1 \%$ TFA, B: ACN $+0.1 \%$ TFA, $10-30 \% \mathrm{~B})$ to yield a colorless solid (47 $\mathrm{mg}, 39 \%)$. LCMS: $R_{\mathrm{t}}=2.14 \mathrm{~min}, 98 \mathrm{~A} \% @ 254 \mathrm{~nm},[\mathrm{M}+\mathrm{H}]^{+}=226.0 .{ }^{1} \mathrm{H}$ NMR $\left(600 \mathrm{MHz}\right.$, DMSO- $\left.d_{6}\right): \delta 7.93(\mathrm{~d}, J=1.2 \mathrm{~Hz}, 1 \mathrm{H}), 7.69-7.65$ (m, 2H), 7.40-7.27 (m, 6H), $5.14(\mathrm{~s}, 2 \mathrm{H}) .{ }^{13} \mathrm{C}$ NMR (151 MHz, DMSO-d $d_{6}: \delta 152.1,136.7,136.0,130.3,128.5,127.6,127.6,121.6$, $117.8,107.4,49.8$. HRMS (ESI) $m / z$ : calcd for $\mathrm{C}_{13} \mathrm{H}_{11} \mathrm{~N}_{3} \mathrm{NaO}[\mathrm{M}+$ $\mathrm{Na}]^{+}, 248.0794$; found, 249.0799 .

7-(4-Fluorobenzyl)imidazo[1,2-a]pyrazin-8(7H)-one; 20c. Imidazopyrazinone $20 \mathrm{a}(100 \mathrm{mg}, 0.740 \mathrm{mmol}), \mathrm{K}_{2} \mathrm{CO}_{3}$, and 4-fluorobenzyl bromide ( 1.2 equiv) were reacted according to general procedure $\mathrm{A}$ at rt for $45 \mathrm{~min}$. The imidazopyrazinone isomer was detected as the preferred isomer (24:1 ratio) by HPLC (UV $254 \mathrm{~nm}$ ). The crude material was purified by recrystallization $(\mathrm{EtOH})$ to yield a colorless solid (34 mg, 19\%). mp $=168-169{ }^{\circ} \mathrm{C}$. LCMS: $R_{\mathrm{t}}=2.94 \mathrm{~min}, 99 \mathrm{~A} \%$ (a $254 \mathrm{~nm},[\mathrm{M}+\mathrm{H}]^{+}=244.1 .{ }^{1} \mathrm{H}$ NMR $\left(400 \mathrm{MHz}, \mathrm{DMSO}-d_{6}\right): \delta$ $7.84-7.78(\mathrm{~m}, 1 \mathrm{H}), 7.61(\mathrm{~d}, J=5.8 \mathrm{~Hz}, 1 \mathrm{H}), 7.52-7.46(\mathrm{~m}, 1 \mathrm{H})$, $7.45-7.36(\mathrm{~m}, 2 \mathrm{H}), 7.24(\mathrm{~d}, J=5.9 \mathrm{~Hz}, 1 \mathrm{H}), 7.22-7.12(\mathrm{~m}, 2 \mathrm{H})$, $5.09(\mathrm{~s}, 2 \mathrm{H}) .{ }^{13} \mathrm{C}$ NMR $\left(150 \mathrm{MHz}, \mathrm{DMSO}-d_{6}\right): \delta 161.6(\mathrm{~d}, J=243.2$ $\mathrm{Hz}), 153.0,137.0,133.4(\mathrm{~d}, J=3.0 \mathrm{~Hz}), 132.7,129.9(\mathrm{~d}, J=8.5 \mathrm{~Hz})$, $120.4,117.6,115.4(\mathrm{~d}, J=21.7 \mathrm{~Hz}), 107.5,49.1$. HRMS (ESI) $m / z$ : calcd for $\mathrm{C}_{13} \mathrm{H}_{11} \mathrm{FN}_{3} \mathrm{O}[\mathrm{M}+\mathrm{H}]^{+}, 244.0881$; found, 244.0884.

$\mathrm{N}$-(Benzyl)-1H-imidazole-2-carboxamide; 22b. $1 \mathrm{H}$-Imidazole-2carboxylic acid 21a $(1.08 \mathrm{~g}, 9.60 \mathrm{mmol})$ was refluxed in $\mathrm{SOCl}_{2}(10$ $\mathrm{mL}$ ) under $\mathrm{N}_{2}$ for $22 \mathrm{~h}$. Volatiles were removed in vacuo, and residual $\mathrm{SOCl}_{2}$ was removed by co-evaporation with toluene to give the crude acid chloride intermediate. Benzylamine $(478 \mu \mathrm{L}, 4.38 \mathrm{mmol})$ was added drop wise to acid chloride (476 mg, $3.65 \mathrm{mmol}$ ) suspended in 
anh. THF $(13 \mathrm{~mL})$ under an atmosphere of $\mathrm{N}_{2}$. The light brown precipitate was filtered and washed with THF to yield a tan solid (685 $\mathrm{mg}, 79 \%)$ that was used without further purification. LCMS: $R_{\mathrm{t}}=2.68$ min, 99 A \% @ $254 \mathrm{~nm},[\mathrm{M}+\mathrm{H}]^{+}=202.1{ }^{1} \mathrm{H}$ NMR $(600 \mathrm{MHz}$, $\left.\mathrm{CDCl}_{3}\right): \delta 8.97(\mathrm{t}, J=5.7 \mathrm{~Hz}, 1 \mathrm{H}), 7.49-7.04(\mathrm{~m}, 7 \mathrm{H}), 4.43(\mathrm{~d}, J=$ $6.2 \mathrm{~Hz}, 2 \mathrm{H}) .{ }^{13} \mathrm{C}$ NMR $\left(150 \mathrm{MHz}, \mathrm{CDCl}_{3}\right): \delta 158.3,140.9,139.5$, 134.0, 128.1, 127.1, 126.6, 119.6 (br), 41.8.

1-(2,2-Diethoxyethyl)-1H-imidazole-2-carboxamide; $23 a$. Imidazole-2-carboxamide $22 \mathrm{a}(650 \mathrm{mg}, 5.85 \mathrm{mmol})$ was reacted according to general procedure A with $\mathrm{K}_{2} \mathrm{CO}_{3}$, bromoacetaldehyde diethyl acetal $(2 \times 1.5$ equiv $)$ at $\mu \mathrm{W} 120{ }^{\circ} \mathrm{C}(2 \times 15 \mathrm{~min})$ to yield a yellow solid that was used without further purification $(1.08 \mathrm{~g}, 81 \%)$. LCMS: $R_{\mathrm{t}}=2.65 \mathrm{~min}, 99 \mathrm{~A} \% @ 254 \mathrm{~nm},[\mathrm{M}+\mathrm{H}-\mathrm{EtOH}]^{+}=182.1 .{ }^{1} \mathrm{H}$ $\operatorname{NMR}\left(400 \mathrm{MHz}, \mathrm{CDCl}_{3}\right): \delta 7.23(\mathrm{br} \mathrm{s}, 1 \mathrm{H}), 7.12(\mathrm{~d}, J=1.1 \mathrm{~Hz}, 1 \mathrm{H})$, $7.01(\mathrm{~d}, J=1.1 \mathrm{~Hz}, 1 \mathrm{H}), 5.33($ br s, $1 \mathrm{H}), 4.84-4.60(\mathrm{~m}, 1 \mathrm{H}), 4.53(\mathrm{~d}$, $J=5.3 \mathrm{~Hz}, 2 \mathrm{H}), 3.73(\mathrm{dq}, J=9.4,7.0 \mathrm{~Hz}, 2 \mathrm{H}), 3.48(\mathrm{dq}, J=9.4,7.0$ $\mathrm{Hz}, 2 \mathrm{H}), 1.16(\mathrm{t}, J=7.0 \mathrm{~Hz}, 6 \mathrm{H}) .{ }^{13} \mathrm{C} \mathrm{NMR}\left(150 \mathrm{MHz} \mathrm{CDCl}_{3}\right): \delta$ 161.1, 137.8, 127.6, 126.7, 101.8, 64.0, 51.0, 15.2. NMR data was consistent with literature. $^{35}$

N-Benzyl-1-(2,2-diethoxyethyl)-1H-imidazole-2-carboxamide; 23b. Imidazole-2-carboxamide 22b (201 $\mathrm{mg}, 0.846 \mathrm{mmol}$ ) was reacted according to general procedure $\mathrm{A}$ with $\mathrm{K}_{2} \mathrm{CO}_{3}$, bromoacetaldehyde diethyl acetal ( 1 equiv, second portion $=0.2$ equiv) at $\mu \mathrm{W}$ $180^{\circ} \mathrm{C}(2 \times 15 \mathrm{~min})$. The crude product was obtained as a yellow oil (246 mg, 92\%) which was used without further purification. LCMS: $R_{\mathrm{t}}=2.37 \mathrm{~min}, 89 \mathrm{~A} \% @ 254 \mathrm{~nm},[\mathrm{M}+\mathrm{H}]^{+}=318.2 .{ }^{1} \mathrm{H}$ NMR $(600$ $\left.\mathrm{MHz}, \mathrm{CDCl}_{3}\right): \delta 7.79(\mathrm{t}, J=6.3 \mathrm{~Hz}, 1 \mathrm{H}), 7.40-7.34(\mathrm{~m}, 4 \mathrm{H}), 7.34-$ $7.30(\mathrm{~m}, 1 \mathrm{H}), 7.14(\mathrm{~d}, J=1.0 \mathrm{~Hz}, 1 \mathrm{H}), 7.01(\mathrm{~d}, J=1.0 \mathrm{~Hz}, 1 \mathrm{H}), 4.79$ $(\mathrm{t}, J=5.5 \mathrm{~Hz}, 1 \mathrm{H}), 4.61(\mathrm{~d}, J=6.3 \mathrm{~Hz}, 2 \mathrm{H}), 4.60(\mathrm{~d}, J=5.5 \mathrm{~Hz}, 2 \mathrm{H})$, $3.77(\mathrm{dq}, J=9.4,7.0 \mathrm{~Hz}, 2 \mathrm{H}), 3.52(\mathrm{dq}, J=9.4,7.0 \mathrm{~Hz}, 2 \mathrm{H}), 1.20(\mathrm{t}, J$ $=7.0 \mathrm{~Hz}, 6 \mathrm{H}) \cdot{ }^{13} \mathrm{C}$ NMR $\left(100 \mathrm{MHz}, \mathrm{CDCl}_{3}\right): \delta 159.0,138.5,137.9$, 128.7, 127.7, 127.5, 127.4, 126.3, 101.9, 64.0, 50.8, 43.1, 15.2. HRMS (ESI) $\mathrm{m} / z$ : calcd for $\mathrm{C}_{34} \mathrm{H}_{46} \mathrm{~N}_{6} \mathrm{NaO}_{6}[2 \mathrm{M}+\mathrm{Na}]^{+}, 657.3371$; found, 657.3392 .

2-Nitro-6-phenylimidazo[1,2-a]pyrazin-8(7H)-one; 24a. Compound $27 \mathrm{a}(230 \mathrm{mg}, 0.839 \mathrm{mmol})$ was reacted according to general procedure $\mathrm{C}$ to yield a crystalline yellow solid $(181 \mathrm{mg}, 84 \%) . \mathrm{mp}=$ $342{ }^{\circ} \mathrm{C}$ (decomposed). LCMS: $R_{\mathrm{t}}=3.05 \mathrm{~min}, 99 \mathrm{~A} \% @ 254 \mathrm{~nm},[\mathrm{M}$ $+\mathrm{H}]^{+}=257.0 .{ }^{1} \mathrm{H}$ NMR $\left(600 \mathrm{MHz}, \mathrm{DMSO}-d_{6}\right): \delta 11.97(\mathrm{~s}, 1 \mathrm{H})$, 8.79-8.73 (s, $1 \mathrm{H}), 7.83(\mathrm{~s}, 1 \mathrm{H}), 7.71-7.64(\mathrm{~m}, 2 \mathrm{H}), 7.57-7.48(\mathrm{~m}$, $3 \mathrm{H}) .{ }^{13} \mathrm{C}$ NMR $\left(150 \mathrm{MHz}, \mathrm{DMSO}-d_{6}\right): \delta 153.6,147.9,134.6,132.1$, $130.7,129.9,129.0,126.8,116.7,104.6$. HRMS (ESI) $\mathrm{m} / z$ : calcd for $\mathrm{C}_{12} \mathrm{H}_{8} \mathrm{~N}_{4} \mathrm{NaO}_{3}[\mathrm{M}+\mathrm{Na}]^{+}$, 279.0489; found, 279.0482 .

2-Nitro-6-phenylimidazo[1,2-a]pyrazin-8(7H)-one; 24a. Imidazole-2-carboxamide 13a (450 mg, $2.34 \mathrm{mmol})$ was reacted according to general procedure $\mathrm{E}$ with 2-bromoacetophenone (1.2 equiv) in anh. DMF (20 vol). $\mathrm{HCl}(2 \mathrm{M}$ aq, $20 \mathrm{vol})$ was then added slowly and the reaction was then heated $\left(\mu \mathrm{W} 120^{\circ} \mathrm{C}\right.$ for $1 \mathrm{~h}, 150{ }^{\circ} \mathrm{C}$ for $\left.15 \mathrm{~min}\right)$, and the product was isolated to yield a brown solid $(242 \mathrm{mg}, 40 \%)$. LCMS: $R_{\mathrm{t}}=3.02 \mathrm{~min}, 98 \mathrm{~A} \%$ @ $254 \mathrm{~nm},[\mathrm{M}+\mathrm{H}]^{+}=257.0 .{ }^{1} \mathrm{H}$ NMR (600 MHz, DMSO- $\left.d_{6}\right): \delta 11.99(\mathrm{~s}, 1 \mathrm{H}), 8.77(\mathrm{~s}, 1 \mathrm{H}), 7.83(\mathrm{~s}$, $1 \mathrm{H}), 7.69-7.67(\mathrm{~m}, 2 \mathrm{H}), 7.55-7.50(\mathrm{~m}, 3 \mathrm{H})$. The proton spectrum is consistent with the preparation that used 4-nitroimidazole $21 \mathrm{a}$ as the starting material.

2-((2-Nitro-6-phenylimidazo[1,2-a]pyrazin-8-yl)oxy)ethyl Acetate; $24 b$ and 2-(2-Nitro-8-oxo-6-phenylimidazo[1,2-a]pyrazin7(8H)-yl)ethyl Acetate; 24c. Imidazopyrazinone 24a (280 mg, 1.09 $\mathrm{mmol}$ ) was reacted according to general procedure $\mathrm{A}$ with $\mathrm{K}_{2} \mathrm{CO}_{3}$ and 2-bromoethylacetate $(2 \times 1.5$ equiv $)$ with heating $\left(2 \times \mu \mathrm{W} 80{ }^{\circ} \mathrm{C}, 30\right.$ $\mathrm{min})$. The crude material contained imidazopyrazinone (minor) and imidazopyrazine (major) isomers in a 1:5.7 ratio as determined by NMR. The crude material was purified over $\mathrm{C} 18$ silica gel by MPLC (Grace Reveleris, A: $\mathrm{H}_{2} \mathrm{O}+0.1 \%$ TFA, B: ACN $+0.1 \%$ TFA, $20-$ $100 \% \mathrm{~B}$ ) to yield imidazopyrazine as a yellow solid (231 $\mathrm{mg}, 62 \%)$ and imidazopyrazinone as a yellow solid (19 $\mathrm{mg}, 5 \%)$. Minor isomer imidazopyrazinone 24b: LCMS: $R_{\mathrm{t}}=2.59 \mathrm{~min}, 99 \mathrm{~A} \% @ 254 \mathrm{~nm}$, $[\mathrm{M}+\mathrm{H}]^{+}=343.0 .{ }^{1} \mathrm{H}$ NMR $\left(600 \mathrm{MHz}, \mathrm{DMSO}-d_{6}\right): \delta 8.74(\mathrm{~s}, 1 \mathrm{H})$, $7.60-7.52(\mathrm{~m}, 5 \mathrm{H}), 7.50(\mathrm{~s}, 1 \mathrm{H}), 4.10-4.02(\mathrm{~m}, 4 \mathrm{H}), 1.89(\mathrm{~s}, 3 \mathrm{H})$. ${ }^{13} \mathrm{C}$ NMR (150 MHz, DMSO- $\left.d_{6}\right): \delta 170.0,153.3,148.1,134.6,134.1$, $131.3,129.9,129.8,128.8,116.1,106.8,60.7,43.4,20.6$. HRMS (ESI) $m / z$ : calcd for $\mathrm{C}_{16} \mathrm{H}_{14} \mathrm{~N}_{4} \mathrm{Na}_{1} \mathrm{O}_{5}[\mathrm{M}+\mathrm{Na}]^{+}, 365.0856$; found, 365.0858. Major isomer imidazopyrazine 24c: LCMS: $R_{\mathrm{t}}=2.93$ min, 99 A \%@254 nm, $[\mathrm{M}+\mathrm{H}]^{+}=343.0 .{ }^{1} \mathrm{H}$ NMR $(600 \mathrm{MHz}$, DMSO- $\left.d_{6}\right): \delta 8.95(\mathrm{~s}, 1 \mathrm{H}), 8.86(\mathrm{~s}, 1 \mathrm{H}), 8.03-7.98(\mathrm{~m}, 2 \mathrm{H}), 7.57-$ $7.51(\mathrm{~m}, 2 \mathrm{H}), 7.49-7.43(\mathrm{~m}, 1 \mathrm{H}), 4.89-4.84(\mathrm{~m}, 2 \mathrm{H}), 4.53-4.48$ (m, 2H), 2.05 (s, 3H). ${ }^{13} \mathrm{C}$ NMR (150 MHz, DMSO-d $\left.d_{6}\right): \delta 170.3$, $153.0,148.4,136.8,135.0,129.5,129.2,128.9,125.7,115.1,111.9$, 65.0, 62.0, 20.7. HRMS (ESI) $\mathrm{m} / z$ : calcd for $\mathrm{C}_{16} \mathrm{H}_{14} \mathrm{~N}_{4} \mathrm{Na}_{1} \mathrm{O}_{5}[\mathrm{M}+$ $\mathrm{Na}]^{+}, 365.0856$; found, 365.0861 .

7-(2-Hydroxyethyl)-2-nitro-6-phenylimidazo[1,2-a]pyrazin8(7H)-one; 24d. Compound 24b (19 $\mathrm{mg}, 55 \mu \mathrm{mol}$ ) was reacted according to general procedure D. After $25 \mathrm{~min}$, volatiles were removed under a stream of $\mathrm{N}_{2}$. The residue was diluted with $\mathrm{H}_{2} \mathrm{O}(2$ $\mathrm{mL})$ and then extracted with EtOAc $(3 \times 2 \mathrm{~mL})$, followed by DCM $(3 \times 2 \mathrm{~mL})$. The organic layer was further diluted with EtOAc (14 $\mathrm{mL})$, washed with brine $(20 \mathrm{~mL})$, dried with anh. $\mathrm{MgSO}_{4}$, and filtered. Volatiles were removed in vacuo to give a yellow residue which was purified over silica gel by MPLC (Grace Reveleris X2, 4$15 \% \mathrm{MeOH}$ in $\mathrm{DCM}$ ) then over $\mathrm{C} 18$ silica gel by MPLC (Grace Reveleris, A: $\mathrm{H}_{2} \mathrm{O}+0.1 \%$ TFA, B: ACN $+0.1 \%$ TFA, $15-40 \%$ B) to yield a yellow-brown solid (3.8 mg, 17\%). LCMS: $R_{\mathrm{t}}=2.52 \mathrm{~min}, 99 \mathrm{~A}$ $\% @ 254 \mathrm{~nm},[\mathrm{M}+\mathrm{H}]^{+}=301.1 .{ }^{1} \mathrm{H}$ NMR $\left(600 \mathrm{MHz}, \mathrm{DMSO}-d_{6}\right): \delta$ $8.73(\mathrm{~s}, 1 \mathrm{H}), 7.59-7.51(\mathrm{~m}, 5 \mathrm{H}), 7.46(\mathrm{~s}, 1 \mathrm{H}), 4.77(\mathrm{~s}, 1 \mathrm{H}), 3.85(\mathrm{t}, J$ $=6.3 \mathrm{~Hz}, 2 \mathrm{H}), 3.43(\mathrm{br} \mathrm{t}, J=6.7 \mathrm{~Hz}, 2 \mathrm{H}) .{ }^{13} \mathrm{C} \mathrm{NMR}(150 \mathrm{MHz}$, DMSO- $\left.d_{6}\right): \delta 153.2,148.0,135.1,134.4,131.7,129.9,129.7,128.6$, 115.9, 106.5, 57.5, 46.6. HRMS (ESI) $m / z$ : calcd for $\mathrm{C}_{14} \mathrm{H}_{12} \mathrm{~N}_{4} \mathrm{Na}_{1} \mathrm{O}_{4}$ $[\mathrm{M}+\mathrm{Na}]^{+}$, 323.0751; found, 323.0759.

2-((2-Nitro-6-phenylimidazo[1,2-a]pyrazin-8-yl)oxy)ethan-1-ol; 24e. Compound $24 \mathrm{c}(146 \mathrm{mg}, 0.427 \mathrm{mmol})$ was reacted according to general procedure $\mathrm{D}$, work-up procedure $\mathrm{B}$. The crude material was purified by MPLC (Grace Reveleris X2, A: $\mathrm{H}_{2} \mathrm{O}+0.1 \%$ TFA, B: ACN $+0.1 \%$ TFA, $30-100 \% \mathrm{~B})$ to yield a bright yellow solid (13 mg, 10\%). LCMS: $R_{\mathrm{t}}=3.36 \mathrm{~min}, 98 \mathrm{~A} \% @ 254 \mathrm{~nm},[\mathrm{M}+\mathrm{H}]^{+}=301.0 .{ }^{1} \mathrm{H}$ NMR $\left(600 \mathrm{MHz}, \mathrm{DMSO}-d_{6}\right): \delta 8.94(\mathrm{~s}, 1 \mathrm{H}), 8.83(\mathrm{~s}, 1 \mathrm{H}), 8.04-7.98$ $(\mathrm{m}, 2 \mathrm{H}), 7.57-7.51(\mathrm{~m}, 2 \mathrm{H}), 7.49-7.43(\mathrm{~m}, 1 \mathrm{H}), 4.69-4.64(\mathrm{~m}$, $2 \mathrm{H}), 3.91-3.86(\mathrm{~m}, 2 \mathrm{H}) .{ }^{13} \mathrm{C}$ NMR $\left(150 \mathrm{MHz}, \mathrm{DMSO}-d_{6}\right): \delta 153.4$, 148.3 , 137.0, 135.1, 129.6, 129.1, 128.9, 125.7, 115.0, 111.6, 68.7, 58.9. HRMS (ESI) $m / z$ : calcd for $\mathrm{C}_{14} \mathrm{H}_{12} \mathrm{~N}_{4} \mathrm{NaO}_{4}[\mathrm{M}+\mathrm{Na}]^{+}$, 323.0751; found, 323.0756 .

6-Methyl-2-nitroimidazo[1,2-a]pyrazin-8(7H)-one; 25a. Imidazole-2-carboxamide $16 \mathrm{a}(1.50 \mathrm{~g}, 7.79 \mathrm{mmol})$ was reacted according to general procedure $\mathrm{E}$ with chloroacetone (1.3 equiv) to yield a yellow solid (1.01 g, 67\%). LCMS: $R_{\mathrm{t}}=2.35 \mathrm{~min}, 99 \mathrm{~A} \% @ 254 \mathrm{~nm}$, $[\mathrm{M}+\mathrm{H}]^{+}=195.0 .{ }^{1} \mathrm{H}$ NMR $\left(600 \mathrm{MHz}, \mathrm{DMSO}-d_{6}\right): \delta 11.66(\mathrm{~s}, 1 \mathrm{H})$, $8.76(\mathrm{~s}, 1 \mathrm{H}), 7.34-7.29(\mathrm{~m}, 1 \mathrm{H}), 2.12(\mathrm{~d}, J=1.2 \mathrm{~Hz}, 3 \mathrm{H}) .{ }^{13} \mathrm{C}$ NMR $\left(150 \mathrm{MHz}, \mathrm{DMSO}-d_{6}\right): \delta 153.4,147.7,134.4,129.5,116.2,103.9$, 15.7. HRMS (ESI) $m / z$ : calcd for $\mathrm{C}_{14} \mathrm{H}_{12} \mathrm{~N}_{8} \mathrm{NaO}_{6}[2 \mathrm{M}+\mathrm{Na}]^{+}$, 411.0772; found, 411.0782 .

2-(6-Methyl-2-nitro-8-oxoimidazo[1,2-a]pyrazin-7(8H)-yl)ethyl Acetate; 25b and 2-((6-Methyl-2-nitroimidazo[1,2-a]pyrazin-8yl)oxy)ethyl; 25c. Compound 25a (150 mg, $0.773 \mathrm{mmol}$ ) was reacted according to general procedure $A$ with $\mathrm{K}_{2} \mathrm{CO}_{3}$ and 2bromoethyl acetate $(2 \times 2$ equiv $)$ with heating $\left(2 \times \mu \mathrm{W} 80{ }^{\circ} \mathrm{C}, 30\right.$ $\mathrm{min})$. The crude material contained imidazopyrazinone (major) and imidazopyrazine (minor) isomers in a 2.4:1 ratio as determined by NMR. The crude solid was purified over silica gel by MPLC (Grace Reveleris $\mathrm{X} 2,0-10 \% \mathrm{MeOH}$ in $\mathrm{DCM}$ gradient) to yield imidazopyrazinone as a yellow solid (140 mg, 48\%) and imidazopyrazine as a yellow solid (57 $\mathrm{mg}, 21 \%)$. Major isomer imidazopyrazinone 25b: LCMS: $R_{\mathrm{t}}=2.80 \mathrm{~min}, 99 \mathrm{~A} \% @ 254 \mathrm{~nm}$, $[\mathrm{M}+\mathrm{H}]^{+}=281.1 .{ }^{1} \mathrm{H}$ NMR $\left(600 \mathrm{MHz}, \mathrm{DMSO}-d_{6}\right): \delta 8.76(\mathrm{~s}, 1 \mathrm{H})$, $7.45(\mathrm{q}, J=1.2 \mathrm{~Hz}, 1 \mathrm{H}), 4.27(\mathrm{t}, J=5.6 \mathrm{~Hz}, 2 \mathrm{H}), 4.21(\mathrm{t}, J=5.5 \mathrm{~Hz}$, $2 \mathrm{H}), 2.35(\mathrm{~d}, J=1.2 \mathrm{~Hz}, 3 \mathrm{H}), 1.98(\mathrm{~s}, 3 \mathrm{H}) .{ }^{13} \mathrm{C}$ NMR $(150 \mathrm{MHz}$, DMSO- $\left.d_{6}\right): \delta 170.2,153.4,147.9,133.8,131.2,115.7,104.8,61.1$, 42.4, 20.6, 16.8. HRMS (ESI) $m / z$ : calcd for $\mathrm{C}_{11} \mathrm{H}_{13} \mathrm{~N}_{4} \mathrm{O}_{5}[\mathrm{M}+\mathrm{H}]^{+}$, 281.0880; found, 281.0878. Minor isomer imidazopyrazine 25c: LCMS: $R_{\mathrm{t}}=3.23 \mathrm{~min}, 99 \mathrm{~A} \% @ 254 \mathrm{~nm},[\mathrm{M}+\mathrm{H}]^{+}=281.1 .{ }^{1} \mathrm{H}$ NMR $\left(600 \mathrm{MHz}\right.$, DMSO- $\left.d_{6}\right): \delta 8.96(\mathrm{~s}, 1 \mathrm{H}), 8.06(\mathrm{q}, J=1.1 \mathrm{~Hz}$, $1 \mathrm{H}), 4.70-4.65(\mathrm{~m}, 2 \mathrm{H}), 4.46-4.41(\mathrm{~m}, 2 \mathrm{H}), 2.33(\mathrm{~d}, J=1.1 \mathrm{~Hz}$, $3 \mathrm{H}), 2.05(\mathrm{~s}, 3 \mathrm{H}) .{ }^{13} \mathrm{C}$ NMR (151 MHz, DMSO): $\delta 170.4,152.8$, 
148.1, 136.9, 129.0, 114.4, 112.4, 64.8, 62.0, 20.7, 20.4. HRMS (ESI) $m / z$ : calcd for $\mathrm{C}_{11} \mathrm{H}_{13} \mathrm{~N}_{4} \mathrm{O}_{5}[\mathrm{M}+\mathrm{H}]^{+}, 281.0880$; found, 281.0890.

7-(2-Hydroxyethyl)-6-methyl-2-nitroimidazo[1,2-a]pyrazin$8(7 \mathrm{H})$-one; $25 d$. Imidazopyrazinone $25 \mathrm{~b}(50 \mathrm{mg}, 0.18 \mathrm{mmol})$ was reacted according to general procedure $\mathrm{D}$, work-up procedure $\mathrm{B}$. The crude material was purified over $\mathrm{C} 18$ silica gel by MPLC (Grace Reveleris, A: $\mathrm{H}_{2} \mathrm{O}+0.1 \%$ TFA, B: ACN $+0.1 \%$ TFA, $5-25 \%$ B) to yield a yellow solid (35 mg, 83\%). LCMS: $R_{\mathrm{t}}=2.42 \mathrm{~min}, 99 \mathrm{~A} \%$ @ $254 \mathrm{~nm},[\mathrm{M}+\mathrm{H}]^{+}=239.0 .{ }^{1} \mathrm{H}$ NMR $\left(600 \mathrm{MHz}\right.$, DMSO- $\left.d_{6}\right): \delta 8.75$ $(\mathrm{s}, 1 \mathrm{H}), 7.42(\mathrm{q}, J=1.2 \mathrm{~Hz}, 1 \mathrm{H}), 4.95(\mathrm{t}, J=5.8 \mathrm{~Hz}, 1 \mathrm{H}), 4.02(\mathrm{t}, J=$ $5.7 \mathrm{~Hz}, 2 \mathrm{H}), 3.64(\mathrm{q}, J=5.7 \mathrm{~Hz}, 2 \mathrm{H}), 2.36(\mathrm{~d}, J=1.2 \mathrm{~Hz}, 3 \mathrm{H}) .{ }^{13} \mathrm{C}$ NMR $\left(150 \mathrm{MHz}\right.$, DMSO- $\left.d_{6}\right): \delta 153.3,147.9,134.0,132.0,115.5$, 104.3, 58.1, 45.9, 17.3. HRMS (ESI) $m / z$ : calcd for $\mathrm{C}_{18} \mathrm{H}_{20} \mathrm{~N}_{8} \mathrm{NaO}_{8}$ $[2 \mathrm{M}+\mathrm{Na}]^{+}, 499.1296$; found, 499.1296 .

2-((6-Methyl-2-nitroimidazo[1,2-a]pyrazin-8-yl)oxy)ethan-1-ol; 25e. Imidazopyrazine $25 \mathrm{c}(20 \mathrm{mg}, 71 \mu \mathrm{mol})$ was reacted according to general procedure $\mathrm{D}$, work-up procedure $\mathrm{B}$. The crude material was purified over C18 silica gel by MPLC (Grace Reveleris, A: $\mathrm{H}_{2} \mathrm{O}+$ $0.1 \%$ TFA, B: ACN $+0.1 \%$ TFA, $10-30 \%$ B) to yield a yellow solid product $(11 \mathrm{mg}, 67 \%)$. LCMS: $R_{\mathrm{t}}=2.78 \mathrm{~min}, 99 \mathrm{~A} \%$ @ $254 \mathrm{~nm},[\mathrm{M}$ $+\mathrm{H}]^{+}=239.0 .{ }^{1} \mathrm{H}$ NMR $\left(600 \mathrm{MHz}, \mathrm{DMSO}-d_{6}\right): \delta 8.94(\mathrm{~s}, 1 \mathrm{H}), 8.03$ $(\mathrm{q}, J=1.1 \mathrm{~Hz}, 1 \mathrm{H}), 5.00(\mathrm{t}, J=5.5 \mathrm{~Hz}, 1 \mathrm{H}), 4.51-4.46(\mathrm{~m}, 2 \mathrm{H})$, $3.84-3.78(\mathrm{~m}, 2 \mathrm{H}), 2.32(\mathrm{~d}, J=1.1 \mathrm{~Hz}, 3 \mathrm{H}) .{ }^{13} \mathrm{C}$ NMR $(150 \mathrm{MHz}$, DMSO- $\left.d_{6}\right): \delta 153.3,148.1,137.1,129.2,114.3,112.0,68.6,58.9$, 20.5. HRMS (ESI) $m / z$ : calcd for $\mathrm{C}_{18} \mathrm{H}_{20} \mathrm{~N}_{8} \mathrm{NaO}_{8}[2 \mathrm{M}+\mathrm{Na}]^{+}$, 499.1296; found, 499.1315.

6-Methyl-2-nitro-7-(4-(trifluoromethoxy)benzyl)imidazo[1,2-a]pyrazin-8(7H)-one; $25 f$ and 6-Methyl-2-nitro-8-((4(trifluoromethoxy)benzyl)oxy)imidazo[1,2-a]pyrazine; 25g. Compound 25a (150 mg, $0.773 \mathrm{mmol}), \mathrm{K}_{2} \mathrm{CO}_{3}$, and 1-(bromomethyl)4(trifluoromethoxy)benzene (1.2 equiv) were reacted according to general procedure $\mathrm{A}$ at $\mathrm{rt}$ for $3 \mathrm{~h}$, work-up $\mathrm{B}$. The crude material contained imidazopyrazinone (major) and imidazopyrazine (minor) isomers in a 7.2:1 ratio by NMR. The crude solid was purified over silica gel by MPLC (Grace Reveleris $\mathrm{X} 2,0-7 \% \mathrm{MeOH}$ in DCM gradient) to yield imidazopyrazinone as an off-white solid (197 mg, $69 \%$ ) and imidazopyrazine as a colorless solid (27 mg, 9\%). Major isomer imidazopyrazinone 25f: LCMS: $R_{\mathrm{t}}=3.52 \mathrm{~min}$, 99 A \% @ 254 $\mathrm{nm},[\mathrm{M}+\mathrm{H}]^{+}=369.0 .{ }^{1} \mathrm{H}$ NMR $\left(600 \mathrm{MHz}\right.$, DMSO- $\left.d_{6}\right): \delta 8.81(\mathrm{~s}$, $1 \mathrm{H}), 7.50(\mathrm{q}, J=1.2 \mathrm{~Hz}, 1 \mathrm{H}), 7.40-7.36(\mathrm{~m}, 2 \mathrm{H}), 7.36-7.32(\mathrm{~m}$, $2 \mathrm{H}), 5.31(\mathrm{~s}, 2 \mathrm{H}), 2.21(\mathrm{~d}, J=1.2 \mathrm{~Hz}, 3 \mathrm{H}) .{ }^{13} \mathrm{C}$ NMR $(150 \mathrm{MHz}$, DMSO- $\left.d_{6}\right): \delta 153.7,148.0,147.4,136.1,134.0,131.0,128.3,121.4$, $120.1(\mathrm{q}, J=256.4 \mathrm{~Hz}), 115.9,105.2,45.3,16.6$. HRMS (ESI) $\mathrm{m} / z$ : calcd for $\mathrm{C}_{15} \mathrm{H}_{12} \mathrm{~F}_{3} \mathrm{~N}_{4} \mathrm{O}_{4}[\mathrm{M}+\mathrm{H}]^{+}, 369.0805$; found, 369.0803 . Minor isomer imidazopyrazine 25g: LCMS: $R_{\mathrm{t}}=3.86 \mathrm{~min}, 99 \mathrm{~A} \%$ @ $254 \mathrm{~nm},[\mathrm{M}+\mathrm{H}]^{+}=369.1{ }^{1} \mathrm{H}$ NMR $\left(600 \mathrm{MHz}, \mathrm{DMSO}-d_{6}\right): \delta 8.96$ $(\mathrm{s}, 1 \mathrm{H}), 8.08(\mathrm{q}, J=1.1 \mathrm{~Hz}, 1 \mathrm{H}), 7.72-7.66(\mathrm{~m}, 2 \mathrm{H}), 7.46-7.41(\mathrm{~m}$, $2 \mathrm{H}), 5.58(\mathrm{~s}, 2 \mathrm{H}), 2.36(\mathrm{~d}, J=1.1 \mathrm{~Hz}, 3 \mathrm{H}) .{ }^{13} \mathrm{C}$ NMR $(151 \mathrm{MHz}$, DMSO): $\delta 152.7,148.2,148.2,137.0,135.3,130.6,129.1,121.1$, $120.1(\mathrm{q}, J=257.1 \mathrm{~Hz}), 114.4,112.5,67.2$, 20.4. HRMS (ESI): $\mathrm{m} / z$ : calcd for $\mathrm{C}_{15} \mathrm{H}_{12} \mathrm{~F}_{3} \mathrm{~N}_{4} \mathrm{NaO}_{4}[\mathrm{M}+\mathrm{Na}]^{+}$, 391.0625; found, 391.0629.

6-Methyl-7-(4-methylbenzyl)-2-nitroimidazo[1,2-a]pyrazin8(7H)-one; $25 \mathrm{~h}$ and 6-Methyl-8-((4-methylbenzyl)oxy)-2nitroimidazo[1,2-a]pyrazine; 25i. Compound 25a (150 mg, 0.773 $\mathrm{mmol}$ ) was reacted according to general procedure method A with $\mathrm{Cs}_{2} \mathrm{CO}_{3}$ and 4-methylbenzyl bromide (1.2 equiv) with heating ( $\mu \mathrm{W}$ $80^{\circ} \mathrm{C}$ for $10 \mathrm{~min}$ and then $90^{\circ} \mathrm{C}$ at $10 \mathrm{~min}$ ) followed by rt overnight, work up $\mathrm{B}$. The crude material contained imidazopyrazinone (major) and imidazopyrazine (minor) isomers in a ratio of $1.8: 1$ by LC-MS (UV $254 \mathrm{~nm}$ ). The crude product was purified over silica gel by MPLC (Biotage Isolera, $0-4 \% \mathrm{DCM} / \mathrm{MeOH}$ ) to give imidazopyrazinone as light yellow powder $(150 \mathrm{mg}, 65 \%)$ and imidazopyrazine as a light orange solid $(21 \mathrm{mg}, 9 \%)$. Major isomer imidazopyrazinone 25h: LCMS: $R_{\mathrm{t}}=2.92 \mathrm{~min}, 99 \mathrm{~A} \% @ 254 \mathrm{~nm},[\mathrm{M}+\mathrm{H}]^{+}=299.1 .{ }^{1} \mathrm{H}$ NMR $\left(600 \mathrm{MHz}\right.$, DMSO- $\left.d_{6}\right): \delta 8.79(\mathrm{~s}, 1 \mathrm{H}), 7.48(\mathrm{~d}, J=1.3 \mathrm{~Hz}$, $1 \mathrm{H}), 7.17-7.08(\mathrm{~m}, 4 \mathrm{H}), 5.24(\mathrm{~s}, 2 \mathrm{H}), 2.27(\mathrm{~s}, 3 \mathrm{H}), 2.20(\mathrm{~d}, J=1.3$ $\mathrm{Hz}, 3 \mathrm{H}) ;{ }^{13} \mathrm{C}$ NMR (150 MHz, DMSO- $\left.d_{6}\right): \delta 153.6,148.0,136.4$, $133.9,133.5,131.1,129.2,126.1,115.8,105.0,45.5,20.6,16.5$. HRMS (ESI) $m / z$ : calcd for $\mathrm{C}_{15} \mathrm{H}_{14} \mathrm{~N}_{4} \mathrm{O}_{3} \mathrm{Na}[\mathrm{M}+\mathrm{Na}]^{+}: 321.0958$, found 321.0957. Minor isomer imidazopyrazine 25i: LCMS: $R_{\mathrm{t}}=3.26$ $\min , 99 \mathrm{~A} \% @ 254 \mathrm{~nm},[\mathrm{M}+\mathrm{H}]^{+}=299.1 ;{ }^{1} \mathrm{H}$ NMR $(600 \mathrm{MHz}$, DMSO- $\left.d_{6}\right): \delta 8.94(\mathrm{~d}, J=0.9 \mathrm{~Hz}, 1 \mathrm{H}), 8.06(\mathrm{t}, J=1.1 \mathrm{~Hz}, 1 \mathrm{H}), 7.43$ $(\mathrm{d}, J=7.8 \mathrm{~Hz}, 2 \mathrm{H}), 7.23(\mathrm{~d}, J=7.7 \mathrm{~Hz}, 2 \mathrm{H}), 5.49(\mathrm{~s}, 2 \mathrm{H}), 2.36(\mathrm{~d}, J=$ $1.1 \mathrm{~Hz}, 3 \mathrm{H}), 2.32(\mathrm{~s}, 3 \mathrm{H}) ;{ }^{13} \mathrm{C}$ NMR $\left(150 \mathrm{MHz}\right.$, DMSO-d $\left.d_{6}\right): \delta 152.9$, 148.1 , 137.7, 137.0, 132.7, 129.1, 129.0, 128.7, 114.3, 112.3, 68.1, 20.8, 20.4. HRMS (ESI) $m / z$ : calcd for $\mathrm{C}_{15} \mathrm{H}_{14} \mathrm{~N}_{4} \mathrm{O}_{3} \mathrm{Na}[\mathrm{M}+\mathrm{Na}]^{+}$: 321.0958 , found 321.0958

6-Methyl-2-nitro-7-(3-(trifluoromethoxy)benzyl)imidazo[1,2-a]pyrazin-8(7H)-one; 25j. Compound 25a (120 mg, $0.618 \mathrm{mmol})$, $\mathrm{Cs}_{2} \mathrm{CO}_{3}$, and 1-(bromomethyl)-3-(trifluoromethoxy)benzene (1.2 equiv) were reacted according to general procedure $\mathrm{A}$ with heating $\left(\mu \mathrm{W} 80{ }^{\circ} \mathrm{C}\right)$ for $10 \mathrm{~min}$, work-up $\mathrm{B}$. The crude material contained imidazopyrazinone (major) and imidazopyrazine (minor) isomers in a ratio of $4.3: 1$ by LC-MS (UV $254 \mathrm{~nm}$ ). The crude product was purified over silica gel by MPLC (Biotage Isolera, 2-4\% DCM/ $\mathrm{MeOH})$ to give imidazopyrazinone as white powder (122 mg, 54\%) and imidazopyrazine as a white solid. Major isomer imidazopyrazinone 25j: LCMS: $R_{\mathrm{t}}=3.49 \mathrm{~min}, 99 \mathrm{~A} \% @ 254 \mathrm{~nm},[\mathrm{M}+\mathrm{H}]^{+}=$ 368.8. ${ }^{1} \mathrm{H}$ NMR $\left(600 \mathrm{MHz}, \mathrm{DMSO}-d_{6}\right): \delta 8.80(\mathrm{~s}, 1 \mathrm{H}), 7.51-7.45$ $(\mathrm{m}, 2 \mathrm{H}), 7.32-7.23(\mathrm{~m}, 3 \mathrm{H}), 5.33(\mathrm{~s}, 2 \mathrm{H}), 2.20(\mathrm{~d}, \mathrm{~J}=1.3 \mathrm{~Hz}, 3 \mathrm{H})$. ${ }^{13} \mathrm{C}$ NMR (150 MHz, DMSO- $\left.d_{6}\right): \delta 153.7,148.6,147.9,139.5,134.0$, $130.9,130.7,125.2,120.0(\mathrm{q}, J=256.9 \mathrm{~Hz}), 119.6,119.1,115.9$, 105.2, 45.4, 16.6. HRMS (ESI) $\mathrm{m} / z$ : calcd for $\mathrm{C}_{15} \mathrm{H}_{11} \mathrm{~F}_{3} \mathrm{~N}_{4} \mathrm{O}_{4} \mathrm{Na}[\mathrm{M}+$ $\mathrm{Na}]^{+}, 391.0624$; found, 391.0625. Minor isomer imidazopyrazine 25k: LCMS: $R_{\mathrm{t}}=3.79 \mathrm{~min}, 65 \mathrm{~A} \% @ 254 \mathrm{~nm},[\mathrm{M}+\mathrm{H}]^{+}=368.8$; impurity detected at $R_{\mathrm{t}}=4.03 \mathrm{~min}, 35 \mathrm{~A} \% @ 254 \mathrm{~nm},[\mathrm{M}+\mathrm{H}]^{+}=737.2$. This compound was not subjected to biological evaluation.

6-Methyl-2-nitro-7-(2-(trifluoromethoxy)benzyl)imidazo[1,2-a]pyrazin-8(7H)-one; $25 \mathrm{I}$ and 6-Methyl-2-nitro-8-((2(trifluoromethoxy)benzyl)oxy)imidazo[1,2-a]pyrazine; $25 \mathrm{~m}$. Compound $25 \mathrm{a}(120 \mathrm{mg}, 0.618 \mathrm{mmol}), \mathrm{Cs}_{2} \mathrm{CO}_{3}$, and 2(trifluoromethoxy)benzyl bromide (1.2 equiv) were reacted according to general procedure A with heating $\left(\mu \mathrm{W} 80^{\circ} \mathrm{C}\right)$ for $10 \mathrm{~min}$, work-up B. The crude material contained imidazopyrazinone (major) and imidazopyrazine (minor) isomers in a ratio of $1.3: 1$ by LC-MS (UV $254 \mathrm{~nm}$ ). The crude product was purified over silica gel by MPLC (Biotage Isolera, $0-4 \% \mathrm{DCM} / \mathrm{MeOH}$ ) to yield imidazopyrazinone as white powder $(76 \mathrm{mg}, 33 \%)$ and imidazopyrazine as cream powder (cream powder, $18 \mathrm{mg}, 8 \%$ ). Major isomer imidazopyrazinone 251 : LCMS: $R_{\mathrm{t}}=3.48 \mathrm{~min}, 99 \mathrm{~A} \% @ 254 \mathrm{~nm},[\mathrm{M}+\mathrm{H}]^{+}=369.0 ;{ }^{1} \mathrm{H}$ NMR $\left(600 \mathrm{MHz}\right.$, DMSO- $\left.d_{6}\right): \delta 8.83(\mathrm{~s}, 1 \mathrm{H}), 7.54(\mathrm{~d}, J=1.3 \mathrm{~Hz}$, $1 \mathrm{H}), 7.49-7.42(\mathrm{~m}, 2 \mathrm{H}), 7.36-7.30(\mathrm{~m}, 1 \mathrm{H}), 7.11(\mathrm{dt}, J=7.8,1.0$ $\mathrm{Hz}, 1 \mathrm{H}), 5.30(\mathrm{~s}, 2 \mathrm{H}), 2.18(\mathrm{~d}, J=1.2 \mathrm{~Hz}, 3 \mathrm{H}) .{ }^{13} \mathrm{C}$ NMR $(150 \mathrm{MHz}$, DMSO- $\left.d_{6}\right): \delta 153.6,148.0,145.6,133.9,130.8,129.2,128.7,127.9$, 127.1, $120.8,120.2(\mathrm{q}, J=257.4 \mathrm{~Hz}), 116.0,105.4,41.3$, 16.2. HRMS (ESI) $\mathrm{m} / z$ : calcd for $\mathrm{C}_{15} \mathrm{H}_{11} \mathrm{~F}_{3} \mathrm{~N}_{4} \mathrm{O}_{4} \mathrm{Na}[\mathrm{M}+\mathrm{Na}]^{+}, 391.0625$; found, 391.0613. Minor isomer imidazopyrazine 25m: LCMS: $R_{\mathrm{t}}=3.78 \mathrm{~min}$, 99 A \% @ $254 \mathrm{~nm},[\mathrm{M}+\mathrm{H}]^{+}=369.0 ;{ }^{1} \mathrm{H}$ NMR $(600 \mathrm{MHz}$, DMSO$\left.d_{6}\right): \delta 8.96(\mathrm{~s}, 1 \mathrm{H}), 8.09(\mathrm{~d}, J=1.3 \mathrm{~Hz}, 1 \mathrm{H}), 7.75(\mathrm{dd}, J=7.6,1.7 \mathrm{~Hz}$, $1 \mathrm{H}), 7.57(\mathrm{td}, J=7.9,1.8 \mathrm{~Hz}, 1 \mathrm{H}), 7.51-7.44(\mathrm{~m}, 2 \mathrm{H}), 5.63(\mathrm{~s}, 2 \mathrm{H})$, $2.36(\mathrm{~d}, J=1.1 \mathrm{~Hz}, 3 \mathrm{H}) ;{ }^{13} \mathrm{C}$ NMR $\left(150 \mathrm{MHz}\right.$, DMSO- $\left.d_{6}\right): \delta 152.5$, $148.2,146.8,136.9,131.4,130.6,128.9,128.3,127.7,120.6,120.1$ (q, $\mathrm{J}=256.4 \mathrm{~Hz}$ ), 114.4, 111.6, 62.5, 20.3. HRMS (ESI) $\mathrm{m} / \mathrm{z}$ : calcd for $\mathrm{C}_{15} \mathrm{H}_{11} \mathrm{~F}_{3} \mathrm{~N}_{4} \mathrm{O}_{4} \mathrm{Na}[\mathrm{M}+\mathrm{Na}]^{+}$, 391.0625; found, 391.0621 .

5,6-Dimethyl-2-nitroimidazo[1,2-a]pyrazin-8(7H)-one; 26a. Imidazole-2-carboxamide $16 \mathrm{a}(750 \mathrm{mg}, 3.89 \mathrm{mmol})$ was reacted according to general procedure $\mathrm{E}$ with 3-bromo-2-butanone (1.5 equiv) to yield a yellow solid (477 mg, 67\%). LCMS: $R_{\mathrm{t}}=2.57 \mathrm{~min}$, 99 A \% @ $254 \mathrm{~nm},[\mathrm{M}+\mathrm{H}]^{+}=209.1 .{ }^{1} \mathrm{H}$ NMR $(600 \mathrm{MHz}, \mathrm{DMSO}-$ $\left.d_{6}\right): \delta 11.55(\mathrm{~s}, 1 \mathrm{H}), 8.82(\mathrm{~s}, 1 \mathrm{H}), 2.32(\mathrm{q}, J=1.0 \mathrm{~Hz}, 3 \mathrm{H}), 2.16(\mathrm{q}, J$ $=1.0 \mathrm{~Hz}, 3 \mathrm{H}) \cdot{ }^{13} \mathrm{C}$ NMR $\left(150 \mathrm{MHz}, \mathrm{DMSO}-d_{6}\right): \delta 152.8,147.9$, 134.6, 124.6, 115.2, 111.0, 14.7, 12.5. HRMS (ESI) $\mathrm{m} / z$ : calcd for $\mathrm{C}_{16} \mathrm{H}_{16} \mathrm{~N}_{8} \mathrm{NaO}_{6}[2 \mathrm{M}+\mathrm{Na}]^{+}$, 439.1085; found, 439.1090 .

6-Methyl-2-nitro-7-(4-(trifluoromethoxy)benzyl)imidazo[1,2-a]pyrazin-8(7H)-one; $26 b$ and 5,6-Dimethyl-2-nitro-8-((4(trifluoromethoxy)benzyl)oxy)imidazo[1,2-a]pyrazine; 26c. Compound $26 \mathrm{a}(150 \mathrm{mg}, 0.721 \mathrm{mmol})$ was reacted according to general procedure A with $\mathrm{K}_{2} \mathrm{CO}_{3}$ and 1-(bromomethyl)4-(trifluoromethoxy)benzene ( 1.2 equiv) at rt overnight. The ratio of $\mathbf{2 6 b} / \mathbf{2 6 c}$ in the crude material was $3: 1$ as determined by LCMS. The crude solid was 
purified over silica gel by MPLC (Grace Reveleris X2, 0-7\% MeOH in DCM gradient) to yield $\mathbf{2 6 \mathbf { b }}$ as a yellow solid (178 $\mathrm{mg}, 69 \%)$ and $25 \mathrm{c}$ as a yellow solid (57 $\mathrm{mg}, 21 \%$ ). Major isomer imidazopyrazinone 26b: LCMS: $R_{\mathrm{t}}=3.61 \mathrm{~min}, 99 \mathrm{~A} \% @ 254 \mathrm{~nm},[\mathrm{M}+\mathrm{H}]^{+}=383.1 .{ }^{1} \mathrm{H}$ NMR $\left(600 \mathrm{MHz}, \mathrm{DMSO}-d_{6}\right): \delta 8.93(\mathrm{~s}, 1 \mathrm{H}), 7.38-7.31(\mathrm{~m}, 4 \mathrm{H})$, $5.37(\mathrm{~s}, 2 \mathrm{H}), 2.43(\mathrm{q}, J=1.0 \mathrm{~Hz}, 3 \mathrm{H}), 2.23(\mathrm{q}, J=1.0 \mathrm{~Hz}, 3 \mathrm{H}) .{ }^{13} \mathrm{C}$ NMR (150 MHz, DMSO-d $\left.d_{6}\right): \delta 153.2,148.1,147.4,136.3,133.9$, 128.2, 126.3, 121.4, $120.1(\mathrm{q}, J=256.1 \mathrm{~Hz}), 115.3,112.5,45.7,14.9$, 13.9. HRMS (ESI) $m / z$ : calcd for $\mathrm{C}_{16} \mathrm{H}_{14} \mathrm{~F}_{3} \mathrm{~N}_{4} \mathrm{O}_{4}[\mathrm{M}+\mathrm{H}]^{+}$, 383.0962; found, 383.0958. Minor isomer imidazopyrazine 26c: LCMS: $R_{\mathrm{t}}=3.94 \mathrm{~min}, 99 \mathrm{~A} \% @ 254 \mathrm{~nm},[\mathrm{M}+\mathrm{H}]^{+}=383.0 .{ }^{1} \mathrm{H}$ NMR $\left(600 \mathrm{MHz}, \mathrm{DMSO}-d_{6}\right): \delta 9.03(\mathrm{~s}, 1 \mathrm{H}), 7.70-7.65(\mathrm{~m}, 2 \mathrm{H})$, $7.45-7.40(\mathrm{~m}, 2 \mathrm{H}), 5.56(\mathrm{~s}, 2 \mathrm{H}), 2.54(\mathrm{q}, J=0.9 \mathrm{~Hz}, 3 \mathrm{H}), 2.40(\mathrm{q}, J$ $=0.9 \mathrm{~Hz}, 3 \mathrm{H}) .{ }^{13} \mathrm{C}$ NMR $\left(150 \mathrm{MHz}, \mathrm{DMSO}-d_{6}\right): \delta 150.8,148.5$, $148.1,135.6,132.8,130.5,129.4,121.1,120.6,120.1(\mathrm{q}, J=255.5$ $\mathrm{Hz}$ ), 113.2, 66.8, 19.6, 13.7. HRMS (ESI) $m / z$ : calcd for $\mathrm{C}_{16} \mathrm{H}_{14} \mathrm{~F}_{3} \mathrm{~N}_{4} \mathrm{O}_{4}[\mathrm{M}+\mathrm{H}]^{+}$, 383.0962; found, 383.0961.

5,6-Dimethyl-7-(4-methylbenzyl)-2-nitroimidazo[1,2-a]pyrazin8(7H)-one; 26d and 5,6-Dimethyl-8-((4-methylbenzyl)oxy)-2nitroimidazo[1,2-a]pyrazine; 26e. Compound 24a (65 mg, 0.312 mmol) was reacted according to general procedure $\mathrm{A}$ with $\mathrm{Cs}_{2} \mathrm{CO}_{3}$ and 4-methylbenzyl bromide (1.2 equiv) with heating ( $\mu \mathrm{W} 80^{\circ} \mathrm{C}, 20$ min then $\mu \mathrm{W} 90^{\circ} \mathrm{C}, 10 \mathrm{~min}$ ) followed by stirring overnight at rt, work up B. The ratio of $26 \mathrm{~d}: 26 \mathrm{e}$ in the crude material was $1.5: 1$ by LCMS (UV $254 \mathrm{~nm}$ ). The crude was purified over silica gel by MPLC (Biotage Isolera, $0-4 \% \mathrm{DCM} / \mathrm{MeOH}$ ) to yield $26 \mathrm{~d}$ as a yellow powder $(39 \mathrm{mg}, 40 \%)$ and $26 \mathrm{e}$ as a light yellow powder $(18 \mathrm{mg}$, 19\%). Major isomer imidazopyrazinone 26d: LCMS: $R_{\mathrm{t}}=3.45 \mathrm{~min}$, $99 \mathrm{~A} \% @ 254 \mathrm{~nm},[\mathrm{M}+\mathrm{H}]^{+}=313.1 .{ }^{1} \mathrm{H}$ NMR $(600 \mathrm{MHz}, \mathrm{DMSO}-$ $\left.d_{6}\right): \delta 8.90(\mathrm{~s}, 1 \mathrm{H}), 7.14(\mathrm{~d}, J=7.9 \mathrm{~Hz}, 2 \mathrm{H}), 7.08(\mathrm{~d}, J=8.1 \mathrm{~Hz}, 2 \mathrm{H})$, $5.30(\mathrm{~s}, 2 \mathrm{H}), 2.42(\mathrm{~d}, J=1.0 \mathrm{~Hz}, 3 \mathrm{H}), 2.27(\mathrm{~s}, 3 \mathrm{H}), 2.22(\mathrm{~d}, J=1.0$ $\mathrm{Hz}, 3 \mathrm{H}) .{ }^{13} \mathrm{C}$ NMR (150 MHz, DMSO- $\left.d_{6}\right): \delta$ 153.2, 148.1, 136.4, 133.9, 133.7, 129.3, 126.5, 126.1, 115.2, 112.3, 46.0, 20.6, 14.8, 13.8 . HRMS (ESI) $m / z$ : calcd for $\mathrm{C}_{16} \mathrm{H}_{16} \mathrm{~N}_{4} \mathrm{O}_{3} \mathrm{Na}[\mathrm{M}+\mathrm{Na}]^{+}$, 335.1115; found, 335.1116. Minor isomer imidazopyrazine 26e: $R_{\mathrm{t}}=3.81 \mathrm{~min}$, 99 A \% @ $254 \mathrm{~nm},[\mathrm{M}+\mathrm{H}]^{+}=313.1 .{ }^{1} \mathrm{H}$ NMR $(600 \mathrm{MHz}$, DMSO$\left.d_{6}\right): \delta 9.01(\mathrm{~s}, 1 \mathrm{H}), 7.44-7.40(\mathrm{~m}, 2 \mathrm{H}), 7.25-7.20(\mathrm{~m}, 2 \mathrm{H}), 5.48(\mathrm{~s}$, $2 \mathrm{H}), 2.55-2.52(\mathrm{~m}, 3 \mathrm{H}), 2.40(\mathrm{~d}, J=1.0 \mathrm{~Hz}, 3 \mathrm{H}), 2.32(\mathrm{~s}, 3 \mathrm{H}) .{ }^{13} \mathrm{C}$ NMR $\left(150 \mathrm{MHz}\right.$, DMSO- $\left.d_{6}\right): \delta 151.0,148.4,137.5,132.9,132.8$, 129.4, 128.9, 128.7, 120.3, 113.1, 67.7, 20.8, 19.6, 13.6. HRMS (ESI) $m / z$ : calcd for $\mathrm{C}_{16} \mathrm{H}_{16} \mathrm{~N}_{4} \mathrm{O}_{3} \mathrm{Na}[\mathrm{M}+\mathrm{Na}]^{+}$, 335.1115; found, 335.1115 .

5,6-Dimethyl-2-nitro-7-(3-(trifluoromethoxy)benzyl)imidazo[1,2a]pyrazin-8(7H)-one; $26 f$ and 5,6-Dimethyl-2-nitro-8-((3(trifluoromethoxy)benzyl)oxy)imidazo[1,2-a]pyrazine; 26g. Compound $26 \mathrm{a}(120 \mathrm{mg}, 0.576 \mathrm{mmol})$ was reacted according to general procedure $\mathrm{A}$ with $\mathrm{Cs}_{2} \mathrm{CO}_{3}$ and 1-(bromomethyl)-3(trifluoromethoxy)benzene (1.2 equiv) with heating $\left(\mu \mathrm{W} 100{ }^{\circ} \mathrm{C}\right)$ for $10 \mathrm{~min}$. The ratio of $\mathbf{2 6 f} / \mathbf{2 6 g}$ in the crude material was $1.2: 1$ by LC-MS (UV $254 \mathrm{~nm}$ ). The crude material was purified over silica gel by MPLC (Biotage Isolera, 0-4\% dichloromethane/methanol) to yield $26 \mathrm{f}$ as a light brown solid $(131 \mathrm{mg}, 60 \%)$ and $26 \mathrm{~g}$ as a yellow gel $(66 \mathrm{mg}, 30 \%)$. Major isomer imidazopyrazinone 26f: LCMS: $R_{\mathrm{t}}=$ $3.56 \mathrm{~min}, 99 \mathrm{~A} \% @ 254 \mathrm{~nm},[\mathrm{M}+\mathrm{H}]^{+}=383.1 .{ }^{1} \mathrm{H} \mathrm{NMR}(600 \mathrm{MHz}$, DMSO- $\left.d_{6}\right): \delta 8.93(\mathrm{~s}, 1 \mathrm{H}), 7.51-7.43(\mathrm{~m}, 1 \mathrm{H}), 7.29(\mathrm{~s}, 1 \mathrm{H}), 7.28-$ $7.21(\mathrm{~m}, 2 \mathrm{H}), 5.39(\mathrm{~s}, 2 \mathrm{H}), 2.43(\mathrm{~d}, J=1.1 \mathrm{~Hz}, 3 \mathrm{H}), 2.24-2.20(\mathrm{~m}$, $3 \mathrm{H}) .{ }^{13} \mathrm{C}$ NMR (150 MHz, DMSO-d 6 ): $\delta 153.3,148.6,148.1,139.7$, 133.9, 130.7, 126.2, 125.1, $120.0(\mathrm{q}, J=256.2 \mathrm{~Hz}), 119.6,119.0$, $115.2,112.4,45.8,14.9$, 13.9. HRMS (ESI) $\mathrm{m} / z$ : calcd for $\mathrm{C}_{32} \mathrm{H}_{26} \mathrm{~F}_{6} \mathrm{~N}_{8} \mathrm{O}_{8} \mathrm{Na}[2 \mathrm{M}+\mathrm{Na}]^{+}, 787.1678$; found, 787.1670. Minor isomer imidazopyrazine 26g: LCMS: $R_{\mathrm{t}}=3.88 \mathrm{~min}, 99 \mathrm{~A} \%$ @ 254 $\mathrm{nm},[\mathrm{M}+\mathrm{H}]^{+}=383.1 .{ }^{1} \mathrm{H}$ NMR $\left(600 \mathrm{MHz}, \mathrm{DMSO}-d_{6}\right): \delta 9.03(\mathrm{~s}$, $1 \mathrm{H}), 7.61-7.51(\mathrm{~m}, 3 \mathrm{H}), 7.40-7.35(\mathrm{~m}, 1 \mathrm{H}), 5.58(\mathrm{~s}, 2 \mathrm{H}), 2.54(\mathrm{~s}$, $3 \mathrm{H}), 2.39(\mathrm{~s}, 3 \mathrm{H}) .{ }^{13} \mathrm{C}$ NMR $\left(150 \mathrm{MHz}, \mathrm{DMSO}-d_{6}\right): \delta 150.7,148.5$, $148.3,138.8,132.7,130.5,129.4,127.5,120.9,120.9,120.7,120.0$ (q, $J=256.2 \mathrm{~Hz}$ ), 113.2, 66.8, 19.6, 13.7. HRMS (ESI) $\mathrm{m} / z$ : calcd for $\mathrm{C}_{16} \mathrm{H}_{13} \mathrm{~F}_{3} \mathrm{~N}_{4} \mathrm{O}_{4} \mathrm{Na}[\mathrm{M}+\mathrm{Na}]^{+}$, 405.0797; found, 405.0781.

5,6-Dimethyl-2-nitro-7-(2-(trifluoromethoxy)benzyl)imidazo[1,2a]pyrazin-8(7H)-one; $26 \mathrm{~h}$ and 5,6-Dimethyl-2-nitro-8-((2(trifluoromethoxy)benzyl)oxy)imidazo[1,2-a]pyrazine; 26i. Com- pound $26 \mathrm{a}(120 \mathrm{mg}, 0.576 \mathrm{mmol})$ was reacted according to general procedure A with $\mathrm{Cs}_{2} \mathrm{CO}_{3}$ and 2-(trifluoromethoxy)benzyl bromide (1.2 equiv) with heating $\left(\mu \mathrm{W} 100{ }^{\circ} \mathrm{C}\right)$ for $10 \mathrm{~min}$. The ratio of $26 \mathbf{h} /$ $26 \mathbf{i}$ in the crude material was 1:2.1 by LC-MS (UV $254 \mathrm{~nm}$ ). The crude material was purified over silica gel by MPLC (Biotage Isolera, $0-4 \% \mathrm{DCM} / \mathrm{MeOH}$ ) to yield $26 \mathrm{~h}$ as a light yellow powder $(46 \mathrm{mg}$, $21 \%$ ) and $26 \mathbf{i}$ as a light yellow powder ( $97 \mathrm{mg}, 44 \%$ ). Minor isomer imidazopyrazinone 26h: LCMS: $R_{\mathrm{t}}=3.15 \mathrm{~min}, 99 \mathrm{~A} \%$ @ $254 \mathrm{~nm}$, $[\mathrm{M}+\mathrm{H}]^{+}=383.1 .{ }^{1} \mathrm{H}$ NMR $\left(600 \mathrm{MHz}, \mathrm{DMSO}-d_{6}\right): \delta 8.95(\mathrm{~s}, 1 \mathrm{H})$, $7.48-7.41(\mathrm{~m}, 2 \mathrm{H}), 7.35-7.29(\mathrm{~m}, 1 \mathrm{H}), 7.06(\mathrm{dt}, J=8.0,1.0 \mathrm{~Hz}$, $1 \mathrm{H}), 5.36(\mathrm{~s}, 2 \mathrm{H}), 2.45(\mathrm{~d}, J=1.0 \mathrm{~Hz}, 3 \mathrm{H}), 2.19(\mathrm{~d}, J=1.0 \mathrm{~Hz}, 3 \mathrm{H})$. ${ }^{13} \mathrm{C}$ NMR (150 MHz, DMSO- $\left.d_{6}\right): \delta 153.1,148.1,145.6,133.8,129.2$, $128.9,127.9,127.1,126.1,120.9,120.3(\mathrm{q}, J=256.8 \mathrm{~Hz}), 115.3$, 112.6, 41.7, 14.5, 13.9. HRMS (ESI) $m / z$ : calcd for $\mathrm{C}_{16} \mathrm{H}_{13} \mathrm{~N}_{4} \mathrm{O}_{4} \mathrm{~F}_{3} \mathrm{Na}$ $[\mathrm{M}+\mathrm{Na}]^{+}, 405.0781$; found, 405.0796. Major isomer imidazopyrazine 26i: LCMS: $R_{\mathrm{t}}=3.44 \mathrm{~min}, 99 \mathrm{~A} \% @ 254 \mathrm{~nm},[\mathrm{M}+\mathrm{H}]^{+}=$ 383.1. ${ }^{1} \mathrm{H}$ NMR $\left(600 \mathrm{MHz}, \mathrm{DMSO}-d_{6}\right): \delta 9.03(\mathrm{~s}, 1 \mathrm{H}), 7.74(\mathrm{dd}, J=$ 7.6, $1.8 \mathrm{~Hz}, 1 \mathrm{H}), 7.55(\mathrm{td}, J=7.8,1.8 \mathrm{~Hz}, 1 \mathrm{H}), 7.50-7.43(\mathrm{~m}, 2 \mathrm{H})$, $5.61(\mathrm{~s}, 2 \mathrm{H}), 2.54(\mathrm{~d}, J=0.9 \mathrm{~Hz}, 3 \mathrm{H}), 2.39(\mathrm{~d}, J=1.0 \mathrm{~Hz}, 3 \mathrm{H}) .{ }^{13} \mathrm{C}$ NMR $\left(150 \mathrm{MHz}, \mathrm{DMSO}-d_{6}\right): \delta 150.6,148.5,146.8,132.7,131.3$, $130.5,129.3,128.5,127.7,120.8,120.6,120.2(\mathrm{q}, J=256.8 \mathrm{~Hz})$, 113.2, 62.2, 19.6, 13.6. HRMS (ESI) $m / z$ : calcd for $\mathrm{C}_{16} \mathrm{H}_{13} \mathrm{~N}_{4} \mathrm{O}_{4} \mathrm{~F}_{3} \mathrm{Na}$ $[\mathrm{M}+\mathrm{Na}]^{+}, 405.0781$; found, 405.0793 .

4-Nitro-1-(2-oxo-2-phenylethyl)-1H-imidazole-2-carboxamide; 27a. Compound 16a (1.20 g, $5.53 \mathrm{mmol}), \mathrm{K}_{2} \mathrm{CO}_{3}$, and 2bromoacetophenone (1.1 equiv) were reacted according to general procedure $\mathrm{A}$ at $\mathrm{rt}$ for $1 \mathrm{~h}$. The crude was purified over silica gel by MPLC (Grace Reveleris X2 15-100\% EtOAc in pet. spirits gradient) to yield an orange oily-solid ( $907 \mathrm{mg}, 60 \%)$. LCMS: $R_{\mathrm{t}}=3.15 \mathrm{~min}, 98$ A \%@ $254 \mathrm{~nm},[\mathrm{M}+\mathrm{H}]^{+}=274.9 .{ }^{1} \mathrm{H}$ NMR $\left(600 \mathrm{MHz}, \mathrm{DMSO}-d_{6}\right)$ : $\delta 8.52(\mathrm{~s}, 1 \mathrm{H}), 8.24(\mathrm{~s}, 1 \mathrm{H}), 8.08-8.02(\mathrm{~m}, 2 \mathrm{H}), 7.78-7.72(\mathrm{~m}, 2 \mathrm{H})$, 7.66-7.59 (m, 2H), $6.13(\mathrm{~s}, 2 \mathrm{H})$. Minor impurities in ${ }^{1} \mathrm{H}$ NMR. ${ }^{13} \mathrm{C}$ NMR $\left(150 \mathrm{MHz}, \mathrm{DMSO}-d_{6}\right): \delta 191.9,159.3,144.5,137.7,134.3$, $134.0,129.1,128.0,126.4$, 55.7. HRMS (ESI) $\mathrm{m} / z$ : calcd for $\mathrm{C}_{12} \mathrm{H}_{10} \mathrm{~N}_{4} \mathrm{NaO}_{4}[\mathrm{M}+\mathrm{Na}]^{+}, 297.0594$; found, 297.0592.

Minimum Inhibition Concentration (MIC) Assay. All compounds were tested for activity against $C$. difficile bacteria (630, ATCC BAA-1382) and representative ESKAPE pathogens S. aureus (MRSA, ATCC 43300), E. coli (FDA control strain, ATCC 25922), K. pneumoniae (MDR, ATCC 700603), A. baumannii (type strain, ATCC 19606), and P. aeruginosa (quality control strain, ATCC 27853) and fungi C. albicans (CLSI reference, ATCC 90028) and C. neoformans (H99 type strain, ATCC 208821) using a standard broth microdilution assay essentially as previously described. ${ }^{49}$ MICs for each strain were determined as the lowest concentration without visible growth. Variance between replicates was typically within one twofold dilution. Median MICs are reported with a range given when the median MIC was between two tested concentrations.

M. tuberculosis H37Rv Minimum Inhibition Assays. The potency of the inhibitors was measured by a resazurin reduction microplate assay as previously described ${ }^{50,51}$ with some alterations. $M$. tuberculosis (H37Rv) was grown in Middlebrook $7 \mathrm{H} 9$ broth medium supplemented with ADC (Difco Laboratories), $0.5 \%$ glycerol, and $0.02 \%$ tyloxapol. Freshly seeded cultures were grown at $37{ }^{\circ} \mathrm{C}$ for approximately 14 days to mid-exponential phase $\left(\mathrm{OD}_{600} 0.4-0.8\right)$ for use in the inhibition assays. Assay plates (96-well microtiter) were prepared with the compound serially diluted in $100 \mu \mathrm{L}$ of $7 \mathrm{H} 9 \mathrm{~S}$ media (7H9 with $10 \%$ ADC, $0.5 \%$ glycerol, $0.05 \%$ Tween- 80 and $1 \%$ tryptone). Mid-exponential phase culture of $M$. tuberculosis $\left(\mathrm{OD}_{600}\right.$ $0.4-0.8$ ) was diluted to $\mathrm{OD}_{600} 0.001$ in $7 \mathrm{H} 9 \mathrm{~S}$ media, and $100 \mu \mathrm{L}$ (representing $\sim 2 \times 10^{4} \mathrm{cfu} / \mathrm{mL}$ ) was added to each well. For normoxic conditions, the plates were incubated for 5 days at $37^{\circ} \mathrm{C}$ in a humidified incubator prior to the addition of $30 \mu \mathrm{L}$ of a $0.02 \%$ resazurin solution and $12.5 \mu \mathrm{L}$ of $20 \%$ Tween-80 to each well. After $24 \mathrm{~h}$ incubation $\left(37^{\circ} \mathrm{C}\right)$, sample fluorescence was measured on a Fluorostar Omega fluorescent plate reader (BMG) with an excitation wavelength of $530 \mathrm{~nm}$ and emission read at $590 \mathrm{~nm}$. Percent fluorescence relative to the positive control wells $(\mathrm{H} 37 \mathrm{Rv}$ without compound) minus the negative control wells (without $\mathrm{H} 37 \mathrm{Rv}$ ) was plotted for the determination of the MIC ( $\leq 90 \%$ reduction in 
growth). The assays were performed in replicate on independent occasions $(n=3-6)$. For hypoxic assays the same method was used except assay plates were incubated for 5 days at $0.1 \%$ oxygen, and after addition of the resazurin solution, the fluorescence was measured after a prolonged incubation time of $48 \mathrm{~h}$.

Antiparasitic Assay: G. lamblia and E. histolytica. Compounds were screened for antiparasitic activity in a 96-well plate using an ATP-bioluminescence based assay for cell growth and survival as previously described. ${ }^{49}$ Briefly, trophozoites of G. lamblia (WB line ${ }^{52}$ ) and E. histolytica (HM1:IMSS) were axenically maintained in TYI-S33 medium supplemented with penicillin $(100 \mathrm{U} / \mathrm{mL})$ and streptomycin $(100 \mu \mathrm{g} / \mathrm{mL}) .^{53}$ All experiments were performed using trophozoites harvested during the logarithmic phase of growth. Twofold serial dilutions were prepared from compound stocks (10 $\mathrm{mM}$ in DMSO) yielding a concentration range of $78 \mu \mathrm{M}-10 \mathrm{mM}$. From this dilution plate, $0.5 \mu \mathrm{L}$ from each well was transferred into 96-well microtitre plates followed by addition of $99.5 \mu \mathrm{L}$ of trophozoites (5000 parasites) to yield a final 8-point concentration range spanning $0.39-50 \mu \mathrm{M}$. Assay plates were incubated for $24-48$ $\mathrm{h}$ at $37{ }^{\circ} \mathrm{C}$ in the GasPak EZ Anaerobe Gas Generating Pouch Systems (VWR, West Chester, PA) to maintain anaerobic conditions throughout the incubation period. Viable cell numbers were determined in triplicate using the CellTiter-Glo Luminescent Cell Viability Assay. ${ }^{54}$

Antiparasitic Assay: T. b. brucei. Compounds were screened for antitrypanosomal activity against T. b. brucei (strain 427, BS427) using an established 384-well resazurin viability assay, as previously described. ${ }^{55-57}$ Briefly, $55 \mu \mathrm{L}$ of HMI-9 media supplemented with $10 \%$ FCS containing 1200 cells $/ \mathrm{mL}$ of logarithmic phase T. b. brucei bloodstream parasites were added to a 384-well microtiter plate (BD Biosciences, USA) and incubated for $24 \mathrm{~h}$ at $37{ }^{\circ} \mathrm{C} / 5 \% \mathrm{CO}_{2}$. Serial compound concentrations were prepared in $100 \% \mathrm{DMSO}$ and diluted 1:21 in Dulbecco's modified Eagles medium. Five microliters of these dilutions was subsequently added to assay plates to give final compound concentrations ranging from a top final assay concentration of 40 or $20 \mu \mathrm{M}$, to $4 \times 10^{-3} \mu \mathrm{M}$ or $2 \times 10^{-3} \mu \mathrm{M}$, respectively. Plates were incubated for $48 \mathrm{~h}$ at $37^{\circ} \mathrm{C} / 5 \% \mathrm{CO}_{2}$. Ten microlitres of $0.49 \mathrm{mM}$ resazurin (Sigma-Aldrich, USA) in HMI-9 media $+10 \%$ FCS was added to assay plates and incubated for a further $2 \mathrm{~h}$ at 37 ${ }^{\circ} \mathrm{C} / 5 \% \mathrm{CO}_{2}$ followed by $22 \mathrm{~h}$ at room temperature. Final assay concentrations of puromycin $(5 \mu \mathrm{M})$ and $0.4 \%$ DMSO were used as in-plate controls for all experiments. Assay plates were read at $535 \mathrm{~nm}$ excitation/590 nm emission on an Envision multiplate reader (PerkinElmer, USA). Nonlinear sigmoidal dose response curves with no constraints were plotted, and $\mathrm{IC}_{50}$ values were calculated in GraphPad Prism 6 (La Jolla, California, USA). The $\mathrm{IC}_{50}$ value was determined for compounds that exhibited a plateau of inhibition (above 90\% inhibition at the top two concentrations) and were calculated from two independent experiments.

Antiparasitic Assay: L. donovani Intracellular Amastigote. Compounds were screened for antileishmanial activity in an established DD8 intracellular (THP-1) amastigote assay as previously described. ${ }^{57}$ Briefly, seven day old $L$. donovani MHOM/IN/80/DD8 (ATCC50212) culture containing metacyclic promastigotes was added to the 384-well assay plates containing transformed THP-1 cells (ATCC TIB202) at $72 \mathrm{~h}$ after the initial cell seeding with a multiplicity of infection of 1:5 (ratio host cells/parasites). Assay plates were incubated $24 \mathrm{~h}$ at $37{ }^{\circ} \mathrm{C} / 5 \% \mathrm{CO}_{2}$. Noninternalized parasites were removed by washing six times in PBS before the addition of 45 $\mu \mathrm{L}$ RMPI (10\% FBS and $25 \mathrm{ng} / \mathrm{mL}$ phorbol 12 -myristate 13 -acetate). Five microliters of compounds was added to wells to give final assay concentrations ranging from 80 to $4 \times 10^{-3} \mu \mathrm{M}$. Final assay concentrations of $2 \mu \mathrm{M}$ of amphotericin B and $0.4 \%$ DMSO were used as in-plate controls for all experiments. Plates were incubated for $96 \mathrm{~h}$ at $37^{\circ} \mathrm{C} / 5 \% \mathrm{CO}_{2}$, fixed with $4 \%$ paraformaldehyde, and stained with SYBR green and CellMask Deep Red plasma membrane dye. Images were acquired on an Opera high-content imaging system (PerkinElmer). Healthy host (THP-1) cells were identified based on fluorescent staining with CellMask Deep Red to characterize the cytoplasm in which the parasite resides and SYBR green to identify both host and parasite nuclei. An infected cell was defined as a host cell containing $>3$ parasites within the cytoplasm boundary. Nonlinear sigmoidal dose response curves with no constraints were plotted, and $\mathrm{IC}_{50}$ values were calculated in GraphPad Prism 6 (La Jolla, California, USA). The $\mathrm{IC}_{50}$ value was determined for compounds that exhibited a plateau of inhibition (above 90\% inhibition at the top two concentrations) and were calculated from two independent experiments.

Mammalian Cytotoxicity Assay. Human HEK293 and HepG2 cells were seeded at 3000 and 5000 cells per well in 384-well plates, respectively. Cells were cultured in Dulbecco's modified Eagle's medium with $10 \% \mathrm{FBS}$ for $24 \mathrm{~h}$ at $37^{\circ} \mathrm{C}, 5 \% \mathrm{CO}_{2}$. A dilution series of compounds was added, with the highest concentration of $100 \mu \mathrm{M}$. The final concentration of DMSO in culture media was $0.5 \%$, which showed no effect on cell growth. After $24 \mathrm{~h}$ incubation with the compounds, $5 \mu \mathrm{M}$ resazurin was added into each well and incubated at $37{ }^{\circ} \mathrm{C}$ for $2 \mathrm{~h}$. As a negative control, $1 \%$ Triton X-100 was added into the culture media to lyse all of the cells. The fluorescence intensity was read using POLARstar Omega with excitation/emission $560 / 590 \mathrm{~nm}$. Data were analyzed with GraphPad Prism 6 software (La Jolla, California USA) to calculate $\mathrm{CC}_{50}$ values.

Microsome Stability. Metabolic stability was determined using pooled human (HMMC-PL, Lot\# PL050B-B, Thermo Fisher Scientific USA) and mouse (CD-1) (MSMCPL, Lot\#MS033D, Thermo Fisher) liver microsomes. The test compound ( $3 \mu \mathrm{M}$, final DMSO concentration $0.2 \%)$ and liver microsomes $(1 \mathrm{mg} / \mathrm{mL})$ were mixed in $100 \mathrm{mM}$ potassium phosphate buffer, $\mathrm{pH} 7.4$ preincubated at $37^{\circ} \mathrm{C}(500 \mu \mathrm{L}$ volume $)$. The reaction was initiated by addition of $\mathrm{NADPH}$ solution (cofactor) in $0.1 \mathrm{M}$ potassium phosphate buffer at a final NADPH concentration of $1 \mathrm{mM}$. The reaction was incubated in a shaking incubator at $37^{\circ} \mathrm{C}, 150 \mathrm{rpm}$. Aliquots $(90 \mu \mathrm{L})$ from the reaction mixture were withdrawn $(\mathrm{t}=0,10,30,60$, and $120 \mathrm{~min})$ and quenched by adding ice-cold precipitating solution $(270 \mu \mathrm{L})$ comprising $0.5 \mu \mathrm{M}$ carbutamide internal standard in acetonitrile/ methanol/formic acid $(1: 1: 0.001 \mathrm{v} / \mathrm{v} / \mathrm{v})$. Reaction samples were incubated at $4{ }^{\circ} \mathrm{C}$ for $30 \mathrm{~min}$ and centrifuged at $14000 \mathrm{~g}$ for $8 \mathrm{~min}$, and the clear supernatant was analyzed by LC/MS/MS. The percentage of the compound remaining at different times was calculated by comparing the peak area ratio of the parent compound (compound peak area/internal standard peak area) at the start of incubation $(t=0 \mathrm{~min}$ sample). All samples were tested in triplicate except for the control samples (without NADPH), matrix blank, and verapamil standard (time points $=0,10$ and $30 \mathrm{~min}$ ). LC/MS/MS parameters are detailed in the Supporting Information Table S4.

Plasma Stability. Plasma stability studies were performed using human (HMPLNAHP, Lot\#BRH1324758, BioReclamationIVT) and mouse (CD-1) plasma (MSEPLNAHP, Lot\#MSE261215, BioReclamationIVT) at five different time points. A solution of plasma and PBS, pH $7.4(50: 50 ; \mathrm{v} / \mathrm{v})$ were preheated at $37{ }^{\circ} \mathrm{C}$ for $30 \mathrm{~min}(240$ $\mu \mathrm{L}$ volume). The reaction was initiated by the addition of the test compounds ( $3 \mu \mathrm{M}$, final DMSO concentration $1 \%)$, and the reaction was incubated in a shaking incubator at $37^{\circ} \mathrm{C}, 150 \mathrm{rpm}$. Aliquots $(40$ $\mu \mathrm{L})$ from the reaction mixture were withdrawn and processed as described for microsome stability assay. All samples were tested in triplicate, and eucatropine was used as a positive control.

Plasma Protein Binding. PPB was performed using an Ultrafiltration method. ${ }^{58,59}$ Fresh frozen human plasma was pooled from O-positive (product number 2799882) and O-negative (product number 5398256) blood from the R \& D division of the Australian Red Cross Blood Services (Brisbane). Test compounds $(5 \mu \mathrm{M})$ were incubated in $100 \%$ human plasma at $37{ }^{\circ} \mathrm{C}$ for $30 \mathrm{~min}(1 \mathrm{~mL}$ volume). For unfiltered samples, an aliquot $(50 \mu \mathrm{L})$ was removed, diluted with PBS $(50 \mu \mathrm{L})$, and quenched with ice-cold precipitating solution comprising $0.5 \mu \mathrm{M}$ carbutamide MS internal standard in acetonitrile/methanol/formic acid (1:1:0.001). Samples were incubated at $4{ }^{\circ} \mathrm{C}$ for $30 \mathrm{~min}$ and then centrifuged at $14000 \mathrm{~g}$ for $8 \mathrm{~min}$ before the clear supernatant was transferred to a vial for LC/MS/MS analysis. For filtered samples, the plasma sample $(250 \mu \mathrm{L})$ was filtered using Amicon Ultra-0.5 Centrifugal Filter Devices 30K NMWL at 14 $000 \mathrm{~g}$ for $7 \mathrm{~min}$, and then an aliquot $(50 \mu \mathrm{L})$ was processed as 
described for unfiltered samples. The fraction of unbound compounds was calculated by determining the concentration of the filtered sample and the concentration of the unfiltered sample. All samples were tested in triplicate with sulfamethoxazole as a control.

Caco-2 Permeability Assay. This study was conducted by WuXi AppTec Co. Ltd. (Shanghai). Caco-2 cells from ATCC were seeded onto polystyrene membranes in 96-well insert plate at $1 \times 10^{5}$ cells/ $\mathrm{cm}^{2}$ until the formation of the confluent cell monolayer at 21st-28th day. Transport buffer used was Hanks' balanced salt solution with 10 $\mathrm{mM}$ 4-(2-hydroxyethyl)-1-piperazineethanesulfonic acid, $\mathrm{pH}$ 7.4. Compounds $(2 \mu \mathrm{M})$ were tested bidirectionally in duplicate. The plate was incubated for $2 \mathrm{~h}$ at $37{ }^{\circ} \mathrm{C}$ and $5 \% \mathrm{CO}_{2}$ at saturated humidity without shaking. All samples were then mixed with acetonitrile containing internal standard and centrifuged at 4000 $\mathrm{rpm}$ for $20 \mathrm{~min}$ and the clear supernatant was diluted 1:1 with water prior to LC/MS/MS analysis. Test compounds and controls (fenoterol, propranolol, and digoxin) in starting solution, donor solution, and receiver solution were quantified using a peak area ratio of analyte/internal standard. To confirm the Caco-2 cell monolayer integrity after the transport assay, lucifer yellow rejection assay was performed. The apparent permeability coefficient $P_{\text {app }}(\mathrm{cm} / \mathrm{s})$ was calculated using the equation: $P_{\text {app }}=\left(\mathrm{d} C_{\mathrm{r}} / \mathrm{d} t\right) \times V_{\mathrm{r}} /\left(A \times C_{0}\right)$ where $\mathrm{d} C_{\mathrm{r}} / \mathrm{d} t$ is the cumulative concentration of the compound in the receiver chamber as a function of time $(\mu \mathrm{M} / \mathrm{s}) ; V_{\mathrm{r}}$ is the solution volume in the receiver chamber $(0.075 \mathrm{~mL}$ on the apical side, $0.25 \mathrm{~mL}$ on the basolateral side); $A$ is the surface area for the transport, that is, $0.0804 \mathrm{~cm}^{2}$ for the area of the monolayer; $C_{0}$ is the initial concentration in the donor chamber $(\mu \mathrm{M})$. The efflux ratio was calculated using the equation: efflux ratio $=P_{\text {app }}(\mathrm{BA}) / P_{\text {app }}(\mathrm{AB})$. Percent recovery was calculated using the equation: \% recovery $=100$ $\times\left[\left(V_{\mathrm{r}} \times C_{\mathrm{r}}\right)+\left(V_{\mathrm{d}} \times C_{\mathrm{d}}\right)\right] /\left(V_{\mathrm{d}} \times C_{0}\right)$ where $V_{\mathrm{d}}$ is the volume in the donor chambers $(0.075 \mathrm{~mL}$ on the apical side, $0.25 \mathrm{~mL}$ on the basolateral side); $C_{\mathrm{d}}$ and $C_{\mathrm{r}}$ are the final concentrations of the transport compound in donor and receiver chambers, respectively.

Solubility Determination. Stock compound solution $(20 \mathrm{mM}$ in DMSO) was aliquoted into water and PBS, pH 7.4 and $0.1 \mathrm{M} \mathrm{HCl}$ ( $\mathrm{pH} 1$ ) to a final concentration of $200 \mu \mathrm{M}, 1 \%$ DMSO. After $24 \mathrm{~h}$ of incubation in a shaking incubator at room temperature, $130 \mathrm{rpm}$, solutions were filtered using centrifuge filter tubes (Corning Costar Spin-X centrifuge tube filters, CLS8169) at $8000 \mathrm{rpm}$ for $1 \mathrm{~min}$. The filtrates were further diluted with acetonitrile $(1: 1, \mathrm{v} / \mathrm{v})$ prior to analysis using LC-UV as detailed in the general Experimental Section. The solubility was determined based on the peak area at UV absorbance $254 \mathrm{~nm}$, with reference to the standard calibration curve prepared from $20 \mathrm{mM}$ DMSO stock. Compounds and standards (caffeine and pretomanid) were prepared in duplicate, and each sample was analyzed in duplicate by LC-UV.

\section{ASSOCIATED CONTENT}

\section{S Supporting Information}

The Supporting Information is available free of charge on the ACS Publications website at DOI: 10.1021/acs.jmedchem.8b01578.

${ }^{1} \mathrm{H}$ and ${ }^{13} \mathrm{C}$ NMR Spectra, 2D NMR and crystal structure data (Figure S1, Tables S1-S3) for 17a, LC/ MS/MS detection and analysis parameters for PPB and metabolic stability, Table S4, supplementary biological data, Tables S5-S8, and solubility data, Table S9 (PDF)

Molecular formula strings (CSV)

\section{AUTHOR INFORMATION}

\section{Corresponding Authors}

*E-mail: m.cooper@uq.edu.au.

*E-mail: m.blaskovich@uq.edu.au. Phone: +61 733462045. +61733462994.
ORCID

Angie M. Jarrad: 0000-0001-9293-1758

Mark S. Butler: 0000-0001-6689-4236

Tomislav Karoli: 0000-0001-6145-8363

Mark A. T. Blaskovich: 0000-0001-9447-2292

Matthew A. Cooper: 0000-0003-3147-3460

\section{Present Addresses}

${ }^{\#}$ Novasep (Dynamit Nobel Explosivstoff und Systemtechnik $\mathrm{GmbH})$, Leverkusen, Germany.

II Department of Chemical Biology, Helmholtz Centre for Infection Research, Inhoffenstrasse 7, 38124, Braunschweig, Germany.

\section{Author Contributions}

${ }^{\perp}$ A.M.J. and C.W.A. contributed equally.

\section{Notes}

The authors declare the following competing financial interest(s): MAC currently holds a fractional Professorial Research Fellow appointment at the University of Queensland with his remaining time as CEO of Inflazome Ltd. a company headquartered in Dublin, Ireland that is developing drugs to address clinical unmet needs in inflammatory disease by targeting the inflammasome.

\section{ACKNOWLEDGMENTS}

We thank Johnny Huang, Geraldine Kaeslin, and Janet Reid for assisting with the cytotoxicity assays and the Community for Open Antimicrobial Drug Discovery ${ }^{40}$ for performing MIC assays against the ESKAPE bacteria and fungal pathogens. We thank Alan Fairlamb and Stephen Patterson of the University of Dundee for providing the R-enantiomer of PA-824. The antimicrobial screening performed by $\mathrm{CO}-\mathrm{ADD}$ was funded by the Wellcome Trust (UK) and The University of Queensland (Australia). AMJ was supported by an Australian Postgraduate Award, IMB Research Scholarship and QLD Government Smart Futures $\mathrm{PhD}$ scholarship and CWA by a Research Training Program scholarship. AD was supported by the National Institutes of Health (grant no.1KL2TR001444). MLS and AJ were supported by ARC grant LP140100560 and NHMRC Project grant APP1067728 awarded to VMA. MAB was supported by Wellcome Trust Strategic Award 104797/Z/ 14/Z and NHMRC Development Grant APP113719. MAC was supported by an NHMRC Principal Research Fellowship APP1059354.

\section{ABBREVIATIONS}

TB, tuberculosis; MIC, minimal inhibitory concentration; SAR, structure activity relationships

\section{REFERENCES}

(1) Ang, C. W.; Jarrad, A. M.; Cooper, M. A.; Blaskovich, M. A. T. Nitroimidazoles: Molecular Fireworks That Combat a Broad Spectrum of Infectious Diseases. J. Med. Chem. 2017, 60, 7636-7657.

(2) Schwebke, J. R.; Morgan, F. G.; Koltun, W.; Nyirjesy, P. A Phase-3, Double-Blind, Placebo-Controlled Study of the Effectiveness and Safety of Single Oral Doses of Secnidazole $2 \mathrm{~g}$ for the Treatment of Women with Bacterial Vaginosis. Am. J. Obstet. Gynecol. 2017, 217, 678.e1-678.e9.

(3) FDA Approves Symbiomix Therapeutics' Solosec (Secnidazole) Oral Granules for the Treatment of Bacterial Vaginosis in Adult Women. https://symbiomix.com/fda-approves-symbiomix-therapeuticssolosec-secnidazole-oral-granules-treatment-bacterial-vaginosis-adultwomen/ (accessed Sep 1, 2018). 
(4) Traynor, K. Benznidazole Approved for Chagas Disease in Children. Am. J. Health-Syst. Pharm. 2017, 74, 1519.

(5) Simarro, P. P.; Cecchi, G.; Franco, J. R.; Paone, M.; Diarra, A.; Ruiz-Postigo, J. A.; Fèvre, E. M.; Mattioli, R. C.; Jannin, J. G. Estimating and Mapping the Population at Risk of Sleeping Sickness. PLoS Neglected Trop. Dis. 2012, 6, e1859.

(6) Tiberi, S.; du Plessis, N.; Walzl, G.; Vjecha, M. J.; Rao, M.; Ntoumi, F.; Mfinanga, S.; Kapata, N.; Mwaba, P.; McHugh, T. D.; Ippolito, G.; Migliori, G. B.; Maeurer, M. J.; Zumla, A. Tuberculosis: Progress and Advances in Development of New Drugs, Treatment Regimens, and Host-Directed Therapies. Lancet Infect. Dis. 2018, 18, e183-e198.

(7) Geneva: World Health Organisation. Global Tuberculosis Report 2017, 2017; pp 1-262.

(8) Matsumoto, M.; Hashizume, H.; Tomishige, T.; Kawasaki, M.; Tsubouchi, H.; Sasaki, H.; Shimokawa, Y.; Komatsu, M. OPC-67683, a Nitro-dihydro-imidazooxazole Derivative with Promising Action Against Tuberculosis In Vitro and in Mice. PLoS Med. 2006, 3, e466.

(9) Sasaki, H.; Haraguchi, Y.; Itotani, M.; Kuroda, H.; Hashizume, H.; Tomishige, T.; Kawasaki, M.; Matsumoto, M.; Komatsu, M.; Tsubouchi, H. Synthesis and Antituberculosis Activity of a Novel Series of Optically Active 6-Nitro-2,3-dihydroimidazo[2,1- $b$ ] oxazoles. J. Med. Chem. 2006, 49, 7854-7860.

(10) Nagarajan, K.; Shankar, R. G.; Rajappa, S.; Shenoy, S.; Costapereira, R. Nitroimidazoles XXI 2,3-Dihydro-6-nitroimidazo [2,1-b] Oxazoles with Antitubercular Activity. Eur. J. Med. Chem. 1989, 24, 631-633.

(11) Ashtekar, D. R.; Costa-Perira, R.; Nagrajan, K.; Vishvanathan, N.; Bhatt, A. D.; Rittel, W. In Vitro and In Vivo Activities of the Nitroimidazole CGI 17341 Against Mycobacterium tuberculosis. Antimicrob. Agents Chemother. 1993, 37, 183-186.

(12) Upton, A. M.; Cho, S.; Yang, T. J.; Kim, Y.; Wang, Y.; Lu, Y.; Wang, B.; Xu, J.; Mdluli, K.; Ma, Z.; Franzblau, S. G. In Vitro and In Vivo Activities of the Nitroimidazole TBA-354 Against Mycobacterium tuberculosis. Antimicrob. Agents Chemother. 2015, 59, 136-144.

(13) Manjunatha, U.; Boshoff, H. I. M.; Barry, C. E. The Mechanism of Action of PA-824: Novel Insights From Transcriptional Profiling. Commun. Integr. Biol. 2014, 2, 215-218.

(14) Singh, R.; Manjunatha, U.; Boshoff, H. I. M.; Ha, Y. H.; Niyomrattanakit, P.; Ledwidge, R.; Dowd, C. S.; Lee, I. Y.; Kim, P.; Zhang, L.; Kang, S.; Keller, T. H.; Jiricek, J.; Barry, C. E. PA-824 Kills Nonreplicating Mycobacterium tuberculosis by Intracellular NO Release. Science 2008, 322, 1392-1395.

(15) Wayne, L. G.; Hayes, L. G. An In Vitro Model for Sequential Study of Shiftdown of Mycobacterium tuberculosis Through Two Stages of Nonreplicating Persistence. Infect. Immun. 1996, 64, 20622069.

(16) Patterson, S.; Wyllie, S.; Stojanovski, L.; Perry, M. R.; Simeons, F. R. C.; Norval, S.; Osuna-Cabello, M.; De Rycker, M.; Read, K. D.; Fairlamb, A. H. The $R$ Enantiomer of the Antitubercular Drug PA-824 as a Potential Oral Treatment for Visceral Leishmaniasis. Antimicrob. Agents Chemother. 2013, 57, 4699-4706.

(17) Wyllie, S.; Roberts, A. J.; Norval, S.; Patterson, S.; Foth, B. J.; Berriman, M.; Read, K. D.; Fairlamb, A. H. Activation of Bicyclic Nitro-Drugs by a Novel Nitroreductase (NTR2) in Leishmania. PLoS Pathog. 2016, 12, e1005971.

(18) Wyllie, S.; Patterson, S.; Stojanovski, L.; Simeons, F. R. C.; Norval, S.; Kime, R.; Read, K. D.; Fairlamb, A. H. The AntiTrypanosome Drug Fexinidazole Shows Potential for Treating Visceral Leishmaniasis. Sci. Transl. Med. 2012, 4, 119 re1.

(19) Thompson, A. M.; Marshall, A. J.; Maes, L.; Yarlett, N.; Bacchi, C. J.; Gaukel, E.; Wring, S. A.; Launay, D.; Braillard, S.; Chatelain, E.; Mowbray, C. E.; Denny, W. A. Assessment of a Pretomanid Analogue Library for African Trypanosomiasis: Hit-to-Lead Studies on 6Substituted 2-Nitro-6,7-dihydro-5H-imidazo[2,1-b][1,3]thiazine 8oxides. Bioorg. Med. Chem. Lett. 2018, 28, 207-213.

(20) Thompson, A. M.; Bonnet, M.; Lee, H. H.; Franzblau, S. G.; Wan, B.; Wong, G. S.; Cooper, C. B.; Denny, W. A. Antitubercular Nitroimidazoles Revisited: Synthesis and Activity of the Authentic 3-
Nitro Isomer of Pretomanid. ACS Med. Chem. Lett. 2017, 8, 12751280.

(21) Kim, P.; Kang, S.; Boshoff, H. I.; Jiricek, J.; Collins, M.; Singh, R.; Manjunatha, U. H.; Niyomrattanakit, P.; Zhang, L.; Goodwin, M.; Dick, T.; Keller, T. H.; Dowd, C. S.; Barry, C. E. Structure-Activity Relationships of Antitubercular Nitroimidazoles. 2. Determinants of Aerobic Activity and Quantitative Structure-Activity Relationships. J. Med. Chem. 2009, 52, 1329-1344.

(22) Lakshminarayana, S. B.; Boshoff, H. I. M.; Cherian, J.; Ravindran, S.; Goh, A.; Jiricek, J.; Nanjundappa, M.; Nayyar, A.; Gurumurthy, M.; Singh, R.; Dick, T.; Blasco, F.; Barry, C. E.; Ho, P. C.; Manjunatha, U. H. Pharmacokinetics-Pharmacodynamics Analysis of Bicyclic 4-Nitroimidazole Analogs in a Murine Model of Tuberculosis. PLoS One 2014, 9, e105222.

(23) Thompson, A. M.; Blaser, A.; Anderson, R. F.; Shinde, S. S.; Franzblau, S. G.; Ma, Z.; Denny, W. A.; Palmer, B. D. Synthesis, Reduction Potentials, and Antitubercular Activity of Ring A/B Analogues of the Bioreductive Drug (6S)-2-Nitro-6-\{[4(trifluoromethoxy)benzyl] oxy\}-6,7-dihydro-5H-imidazo[2,1-b][1,3]oxazine (PA-824). J. Med. Chem. 2009, 52, 637-645.

(24) Drugs for Neglected Diseases initiative. Nitroimidazoles (VL) -DNDi. https://www.dndi.org/diseases-projects/portfolio/ nitroimidazole/ (accessed Sep 1, 2018).

(25) Thompson, A. M.; O’Connor, P. D.; Marshall, A. J.; Yardley, V.; Maes, L.; Gupta, S.; Launay, D.; Braillard, S.; Chatelain, E.; Franzblau, S. G.; Wan, B.; Wang, Y.; Ma, Z.; Cooper, C. B.; Denny, W. A. 7-Substituted 2-Nitro-5,6-dihydroimidazo[2,1-b][1,3] oxazines: Novel Antitubercular Agents Lead to a New Preclinical Candidate for Visceral Leishmaniasis. J. Med. Chem. 2017, 60, 4212-4233.

(26) Thompson, A. M.; O’Connor, P. D.; Marshall, A. J.; Blaser, A.; Yardley, V.; Maes, L.; Gupta, S.; Launay, D.; Braillard, S.; Chatelain, E.; Wan, B.; Franzblau, S. G.; Ma, Z.; Cooper, C. B.; Denny, W. A. Development of (6R)-2-Nitro-6-[4-(trifluoromethoxy)phenoxy]-6,7dihydro-5H-imidazo[2,1- $b][1,3]$ oxazine (DNDI-8219): A New Lead for Visceral Leishmaniasis. J. Med. Chem. 2018, 61, 2329-2352.

(27) Thompson, A. M.; Blaser, A.; Palmer, B. D.; Anderson, R. F.; Shinde, S. S.; Launay, D.; Chatelain, E.; Maes, L.; Franzblau, S. G.; Wan, B.; Wang, Y.; Ma, Z.; Denny, W. A. 6-Nitro-2,3-dihydroimidazo$[2,1-b][1,3]$ thiazoles: Facile Synthesis and Comparative Appraisal Against Tuberculosis and Neglected Tropical Diseases. Bioorg. Med. Chem. Lett. 2017, 27, 2583-2589.

(28) Jarrad, A. M.; Debnath, A.; Miyamoto, Y.; Hansford, K. A.; Pelingon, R.; Butler, M. S.; Bains, T.; Karoli, T.; Blaskovich, M. A. T.; Eckmann, L.; Cooper, M. A. Nitroimidazole Carboxamides as Antiparasitic Agents Targeting Giardia lamblia, Entamoeba histolytica and Trichomonas vaginalis. Eur. J. Med. Chem. 2016, 120, 353-362.

(29) Goodacre, S. C.; Hallett, D. J.; Carling, R. W.; Castro, J. L.; Reynolds, D. S.; Pike, A.; Wafford, K. A.; Newman, R.; Atack, J. R.; Street, L. J. Imidazo[1,2-a]pyrazin-8-ones, Imidazo[1,2-d][1,2,4]triazin-8-ones and Imidazo[2,1-f][1,2,4] triazin-8-ones as $\alpha 2 / \alpha 3$ Subtype Selective GABAA Agonists for the Treatment of Anxiety. Bioorg. Med. Chem. Lett. 2006, 16, 1582-1585.

(30) Mignani, S.; Aloup, J.-C.; Barreau, M.; Blanchard, J. C.; Böhme, G. A.; Boireau, A.; Damour, D.; Debono, M.-W.; Dubroeucq, M.-C.; Genevois-Borella, A.; Imperato, A.; Jimonet, P.; Pratt, J.; Randle, J. C. R.; Reibaud, M.; Ribeill, Y.; Stutzmann, J.-M. Synthesis and Pharmacological Properties of $5 H, 10 H$-imidazo[1,2-a]indeno[1,2e]pyrazine-4-one, A New Competitive AMPA/KA Receptor Antagonist. Drug Dev. Res. 1999, 48, 121-129.

(31) Stutzmann, J.-M.; Bohme, G. A.; Boireau, A.; Damour, D.; Debono, M. W.; Genevois-Borella, A.; Imperato, A.; Jimonet, P.; Pratt, J.; Randle, J. C. R.; Ribeill, Y.; Vuilhorgne, M.; Mignani, S. 4,10Dihydro-4-oxo-4H-imidazo[1,2-a]indeno[1,2-e]pyrazin-2-carboxylic Acid Derivatives. Bioorg. Med. Chem. Lett. 2000, 10, 1133-1137.

(32) Plouvier, B. M. C.; Fedida, D.; Beatch, G. N.; Chou, D. T. H.; Yifru, A. S.; Jung, G. Imidazo Compounds and Uses Thereof. WO 2005/034837, April 21, 2005.

(33) Couturier, C.; Silve, S.; Morales, R.; Pessegue, B.; Llopart, S.; Nair, A.; Bauer, A.; Scheiper, B.; Pöverlein, C.; Ganzhorn, A.; 
Lagrange, S.; Bacqué, E. Nanomolar Inhibitors of Mycobacterium tuberculosis Glutamine Synthetase 1: Synthesis, Biological Evaluation and X-Ray Crystallographic Studies. Bioorg. Med. Chem. Lett. 2015, $25,1455-1459$.

(34) Rao, A. K. S. B.; Rao, C. G.; Singh, B. B. Regioselective Alkylation of 4(5)-Nitro-1H-imidazoles in Acidic Media: Study of Temperature Effects. J. Chem. Soc., Perkin Trans. 1 1994, 2399-2402.

(35) Prévot, I.; Leumann, C. J. Evaluation of Novel Third-Strand Bases for the Recognition of a C.G Base Pair in the Parallel DNA Triple-Helical Binding Motif. Helv. Chim. Acta 2002, 85, 502-515.

(36) Plettenburg, O.; Hofmeister, A.; Kadereit, D.; Brendel, J.; Loehn, M. Cyclohexylamin Isoquinolone Derivatives as Rho-Kinase Inhibitors. WO 2007012422A1, Feb 1, 2007.

(37) Van der Eycken, E.; Singh, B.; Cavalluzzo, C.; De Maeyer, M.; Debyser, Z.; Parmar, V. Microwave-Assisted Silver(I)-Mediated Selective O-Alkylation of Aromatic Imidate Systems. Synthesis 2009, $16,2725-2728$

(38) Semple, G.; Andersson, B.-M.; Chhajlani, V.; Georgsson, J.; Johansson, M. J.; Rosenquist, Å.; Swanson, L. Synthesis and Biological Activity of Kappa Opioid Receptor Agonists. Part 2: Preparation of 3Aryl-2-pyridone Analogues Generated by Solution- and Solid-Phase Parallel Synthesis Methods. Bioorg. Med. Chem. Lett. 2003, 13, 11411145.

(39) Gurumurthy, M.; Mukherjee, T.; Dowd, C. S.; Singh, R.; Niyomrattanakit, P.; Tay, J. A.; Nayyar, A.; Lee, Y. S.; Cherian, J.; Boshoff, H. I.; Dick, T.; Barry, C. E., III; Manjunatha, U. H. Substrate Specificity of the Deazaflavin-Dependent Nitroreductase from Mycobacterium tuberculosis Responsible for the Bioreductive Activation of Bicyclic Nitroimidazoles. FEBS J. 2011, 279, 113-125.

(40) Blaskovich, M. A. T.; Zuegg, J.; Elliott, A. G.; Cooper, M. A. Helping Chemists Discover New Antibiotics. ACS Infect. Dis. 2015, 1, 285-287.

(41) Kim, P.; Zhang, L.; Manjunatha, U. H.; Singh, R.; Patel, S.; Jiricek, J.; Keller, T. H.; Boshoff, H. I.; Barry, C. E., III; Dowd, C. S. Structure-Activity Relationships of Antitubercular Nitroimidazoles. 1. Structural Features Associated with Aerobic and Anaerobic Activities of 4- and 5-Nitroimidazoles. J. Med. Chem. 2009, 52, 1317-1328.

(42) Liu, X.; Wright, M.; Hop, C. E. C. A. Rational Use of Plasma Protein and Tissue Binding Data in Drug Design. J. Med. Chem. 2014, 57, 8238-8248

(43) De Angelis, I.; Turco, L. Caco-2 Cells as a Model for Intestinal Absorption. Curr. Protoc. Toxicol. 2011, 47, 20.6.1-20.6.15.

(44) Xavier, A.; Lakshmanan, M. Delamanid: A New Armor in Combating Drug-Resistant Tuberculosis. J. Pharmacol. Pharmacother. 2014, 5, 222-224.

(45) Katsuno, K.; Burrows, J. N.; Duncan, K.; van Huijsduijnen, R. H.; Kaneko, T.; Kita, K.; Mowbray, C. E.; Schmatz, D.; Warner, P.; Slingsby, B. T. Hit and Lead Criteria in Drug Discovery for Infectious Diseases of the Developing World. Nat. Rev. Drug Discovery 2015, 14, $751-758$.

(46) Blaser, A.; Palmer, B. D.; Sutherland, H. S.; Kmentova, I.; Franzblau, S. G.; Wan, B.; Wang, Y.; Ma, Z.; Thompson, A. M.; Denny, W. A. Structure-Activity Relationships for Amide-, Carbamate-, And Urea-Linked Analogues of the Tuberculosis Drug (6S)-2Nitro-6-\{[4-(trifluoromethoxy)benzyl] oxy $\}-6,7$-dihydro-5H-imidazo[2,1-b][1,3] oxazine (PA-824). J. Med. Chem. 2011, 55, 312-326.

(47) Sutherland, H. S.; Blaser, A.; Kmentova, I.; Franzblau, S. G.; Wan, B.; Wang, Y.; Ma, Z.; Palmer, B. D.; Denny, W. A.; Thompson, A. M. Synthesis and Structure-activity Relationships of Antitubercular 2-Nitroimidazooxazines Bearing Heterocyclic Side Chains. J. Med. Chem. 2010, 53, 855-866.

(48) Dreier, L.; Wider, G. Concentration Measurements by PULCON Using X-Filtered or 2D NMR Spectra. Magn. Reson. Chem. 2006, 44, S206-S212.

(49) Jarrad, A. M.; Karoli, T.; Debnath, A.; Tay, C. Y.; Huang, J. X.; Kaeslin, G.; Elliott, A. G.; Miyamoto, Y.; Ramu, S.; Kavanagh, A. M.; Zuegg, J.; Eckmann, L.; Blaskovich, M. A. T.; Cooper, M. A. Metronidazole-Triazole Conjugates: Activity Against Clostridium difficile and Parasites. Eur. J. Med. Chem. 2015, 101, 96-102.
(50) Tran, A. T.; West, N. P.; Britton, W. J.; Payne, R. J. Elucidation of Mycobacterium tuberculosis Type II Dehydroquinase Inhibitors using a Fragment Elaboration Strategy. ChemMedChem 2012, 7, $1031-1043$.

(51) Taneja, N. K.; Tyagi, J. S. Resazurin Reduction Assays for Screening of Anti-Tubercular Compounds Against Dormant and Actively Growing Mycobacterium tuberculosis, Mycobacterium bovis BCG and Mycobacterium smegmatis. J. Antimicrob. Chemother. 2007, 60, 288-293.

(52) Townson, S. M.; Laqua, H.; Upcroft, P.; Boreham, P. F. L.; Upcroft, J. A. Induction of Metronidazole and Furazolidone Resistance in Giardia. Trans. R. Soc. Trop. Med. Hyg. 1992, 86, $521-522$.

(53) Diamond, L. S.; Harlow, D. R.; Cunnick, C. C. A New Medium for the Axenic Cultivation of Entamoeba histolytica and Other Entamoeba. Trans. R. Soc. Trop. Med. Hyg. 1978, 72, 431-432.

(54) Debnath, A.; Parsonage, D.; Andrade, R. M.; He, C.; Cobo, E. R.; Hirata, K.; Chen, S.; García-Rivera, G.; Orozco, E.; Martínez, M. B.; Gunatilleke, S. S.; Barrios, A. M.; Arkin, M. R.; Poole, L. B.; McKerrow, J. H.; Reed, S. L. A High-Throughput Drug Screen for Entamoeba histolytica Identifies a New Lead and Target. Nat. Med. 2012, 18, 956-960.

(55) Sykes, M. L.; Avery, V. M. Development of an Alamar Blue Viability Assay in 384-Well Format for High Throughput Whole Cell Screening of Trypanosoma brucei brucei Bloodstream Form Strain 427. Am. J. Trop. Med. Hyg. 2009, 81, 665-674.

(56) Sykes, M. L.; Baell, J. B.; Kaiser, M.; Chatelain, E.; Moawad, S. R.; Ganame, D.; Ioset, J.-R.; Avery, V. M. Identification of Compounds with Anti-Proliferative Activity Against Trypanosoma brucei brucei Strain 427 by a Whole Cell Viability Based HTS Campaign. PLoS Neglected Trop. Dis. 2012, 6, e1896.

(57) Duffy, S.; Sykes, M. L.; Jones, A. J.; Shelper, T. B.; Simpson, M.; Lang, R.; Poulsen, S.-A.; Sleebs, B. E.; Avery, V. M. Screening the Medicines for Malaria Venture Pathogen Box Across Multiple Pathogens Reclassifies Starting Points for Open-Source Drug Discovery. Antimicrob. Agents Chemother. 2017, 61 (9).

(58) Zhang, F.; Xue, J.; Shao, J.; Jia, L. Compilation of 222 Drugs' Plasma Protein Binding Data and Guidance for Study Designs. Drug Discovery Today 2012, 17, 475-485.

(59) Di, L.; Kerns, E. H. Plasma Protein Binding Methods. Drug-like Properties: Concepts, Structure Design and Methods; Academic Press: San Diego, CA, 2008; pp 372-377. 